\title{
Relocation of the Salvador Camarena Burial: Historical and Bioarcheological Investigations of a Mexican Migrant Worker Grave (41MV372) in Maverick County, Texas
}

Douglas K. Boyd

Prewitt and Associates, Inc.

Amy E. Dase

Christopher W. Ringstaff

M. Katherine Spradley

Catrina Banks Whitley

Follow this and additional works at: https://scholarworks.sfasu.edu/ita

Part of the American Material Culture Commons, Archaeological Anthropology Commons, Environmental Studies Commons, Other American Studies Commons, Other Arts and Humanities Commons, Other History of Art, Architecture, and Archaeology Commons, and the United States History Commons

Tell us how this article helped you.

This Article is brought to you for free and open access by the Center for Regional Heritage Research at SFA ScholarWorks. It has been accepted for inclusion in Index of Texas Archaeology: Open Access Gray Literature from the Lone Star State by an authorized editor of SFA ScholarWorks. For more information, please contact cdsscholarworks@sfasu.edu. 


\section{Relocation of the Salvador Camarena Burial: Historical and Bioarcheological Investigations of a Mexican Migrant Worker Grave (41MV372) in Maverick County, Texas}

\section{Licensing Statement}

This is a work for hire produced for the Texas Department of Transportation (TxDOT), which owns all rights, title, and interest in and to all data and other information developed for this project under its contract with the report producer. The report may be cited and brief passages from this publication may be reproduced without permission provided that credit is given to TxDOT and the firm that produced it. Permission to reprint an entire chapter, section, figures or tables must be obtained in advance from the Supervisor of the Archeological Studies Branch, Environmental Affairs Division, Texas Department of Transportation, 125 East 11th Street, Austin, Texas, 78701 


\title{
RELOCATION OF THE SALVADOR CAMARENA BURIAL: HISTORICAL AND BIOARCHEOLOGICAL INVESTIGATIONS OF A MEXICAN MIGRANT WORKER GRAVE (41MV372) IN MAVERICK COUNTY, TEXAS
}

\author{
by \\ Douglas K. Boyd, Amy E. Dase, Christopher W. Ringstaff, \\ M. Katherine Spradley, and Catrina Banks Whitley \\ with a contribution by Waldo Troell
}

Principal Investigator: Christopher W. Ringstaff

TECHNICAL REPORTS, NO. 98

Prewitt and Associates, Inc. Cultural Resources Services Austin, Texas

PAI Project Nos. 212001 and 214008

ARCHEOLOGICAL STUDIES PROGRAM, REPORT NO. 162

Texas Department of Transportation

Environmental Affairs Division

Archeological Studies Branch

Austin, Texas

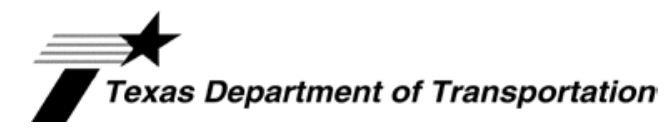

TEXAS ANTIQUITIES PERMIT NO. 6043 


\title{
RELOCATION OF THE SALVADOR CAMARENA BURIAL: HISTORICAL AND BIOARCHEOLOGICAL INVESTIGATIONS OF A MEXICAN MIGRANT WORKER GRAVE (41MV372) IN MAVERICK COUNTY, TEXAS
}

\author{
COPYRIGHT @ 2014
}

Texas Department of Transportation (TxDOT)

This is a work for hire produced by the Texas Department of Transportation (TxDOT), which owns all rights, title, and interest in and to all data and other information developed for this project under Contract No. 57309SA003, Work Authorizations 57108SA001 and 57309SA003. Brief passages from this publication may be reproduced without permission provided that credit is given to TxDOT and Prewitt and Associates, Inc. Permission to reprint an entire chapter, section, figures, or tables must be obtained in advance from the Supervisor of the Archeological Studies Branch, Environmental Affairs Division, Texas Department of Transportation, 125 East 11th Street, Austin, Texas, 78701. A copy of this final report will be submitted to the Texas State Library and Archives Commission, State Publications Depository Program in compliance with 13 TAC §26.24(a).

jointly published by the

Texas Department of Transportation

Environmental Affairs Division

Archeological Studies Branch

Scott Pletka, Ph.D., Supervisor

Archeological Studies Program, Report No. 162

CSJ No. 1590-03-965

and

Prewitt and Associates, Inc.

Cultural Resources Services

Austin, Texas

PAI Project Nos. 212001 and 214008

Technical Reports, No. 98

Printed by Morgan Printing in Austin, Texas

ISBN 978-1-935545-29-3 


\section{TABLE OF CONTENTS}

ABSTRACT

vii

ACKNOWLEDGMENTS

viii

CHAPTER 1: INTRODUCTION TO THE CAMARENA GRAVE PROJECT

\section{1}

CHAPTER 2: HISTORICAL AND BIOARCHEOLOGICAL INVESTIGATIONS OF THE CAMARENA GRAVESITE .......................................................................... 5

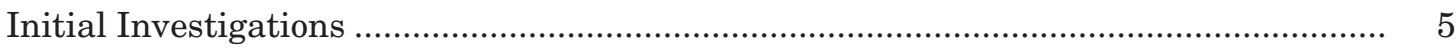

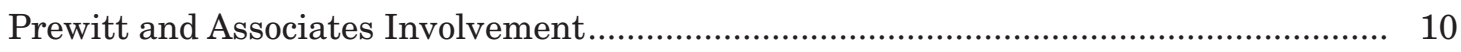

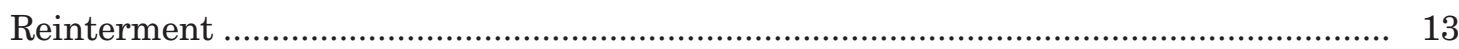

CHAPTER 3: HISTORY OF SALVADOR CAMARENA (1897-1950) AND THE

SEARCH FOR RELATIVES .................................................................. 15

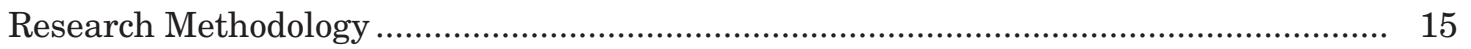

Results of Archival and Informant Research........................................................... 17

CHAPTER 4: EXCAVATION AND DESCRIPTION OF SALVADOR CAMARENA'S GRAVE........ 21

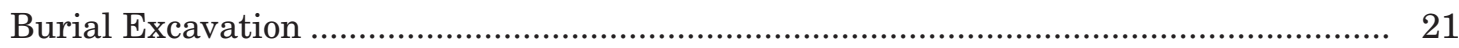

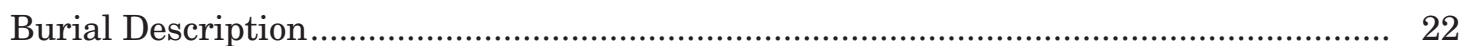

Mortuary Characteristics and Burial Taphonomy ...................................... 22

Summary of the Osteological Interpretations ............................................... 22

Description of Personal and Mortuary Items ............................................... 25

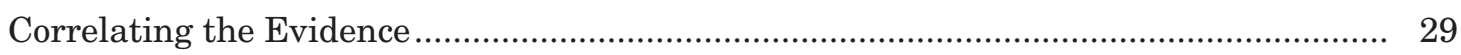

CHAPTER 5: ANALYSIS OF HUMAN REMAINS ..........................................................

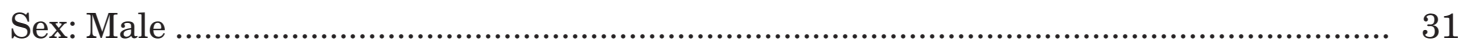

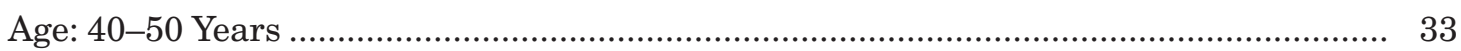

Biological Affiliation: Most Similar to Modern Mexicans .............................................. 33

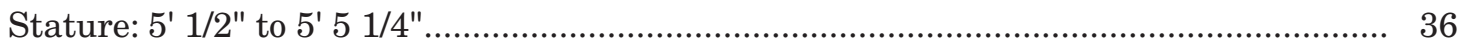

Oral Health: Carious Lesions and Antemortem Tooth Loss ......................................... 36

Pathology and Musculskeletal Markers of Stress .................................................... 37

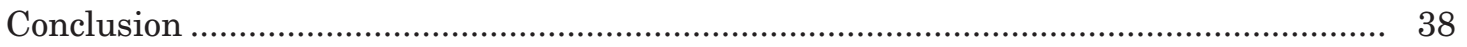

CHAPTER 6: SALVADOR CAMARENA AND THE PLIGHT OF MIGRANT WORKERS........... 39

The Fate of Salvador Camarena................................................................................... 39

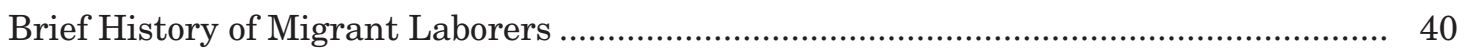

The Ongoing Saga of Border-Crossing Deaths ........................................................... 43

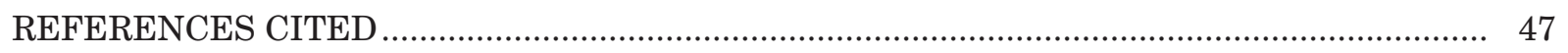

APPENDIX A: Timeline of Events and Key Documents ........................................................... 53

APPENDIX B: Osteological Data for the Salvador Camarena Burial ....................................... 89 


\section{LIST OF FIGURES}

1.1. Map showing the location of the original Salvador Camarena gravesite along FM 481 in Maverick County, Texas

2.1. Photograph of the gravesite taken on July 19, 2010. Photograph courtesy of TxDOT Laredo District.

2.2. Location of the Camarena gravesite as shown on the USGS 1974 Trosado Tank Quadrangle (7.5 minute)

2.3. Photograph of the Gradall lifting the iron fence to remove it prior to the

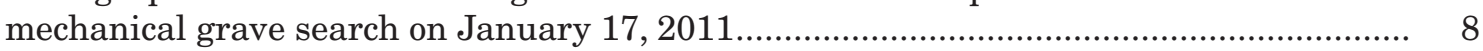

2.4. Photographs of Gradall scraping at the gravesite on January 17, 2011 ......................... 8

2.5. Photographs of Gradall backfilling at the gravesite

2.6. Polacolor photograph of the iron fence and cross marking the grave of Salvador Camarena

2.7. The iron-pipe cross that originally marked the Camarena grave was repainted and placed along the west edge of the right of way

2.8. Photographs of the new headstone marking the reinterment grave of Salvador Camarena in the La Marque Cemetery

3.1. The certificate of death for Salvador Camarena

3.2. Section of a 1961 Maverick County map showing the location of a grave along the county road between Elm and Salado Creeks

4.1. Photographs of the Camarena gravesite excavations in progress.

4.2. Plan map of the Camarena grave with remains exposed between 26 and $39 \mathrm{~cm}$ below the surface

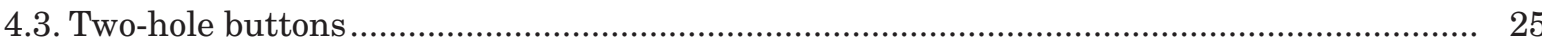

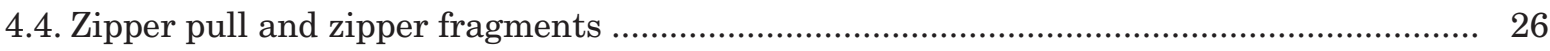

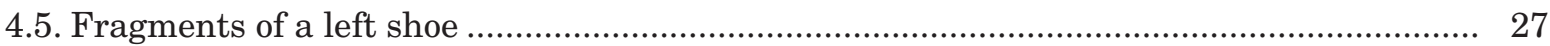

4.6. Metal wristwatch and wristband remnant, views of front and back sides ....................... 28

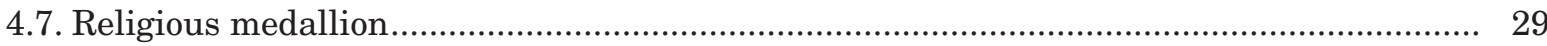

4.8. Fabric remnants from an artificial floral arrangement .................................................. 30

5.1. Schematic inventory of skeletal remains from the Camarena burial ............................... 32

5.2. Closeup views of the left and right pubic symphyses .................................................... 34

5.3. Closeup views of the left and right auricular surfaces ...................................................... 35

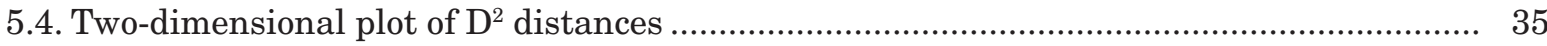

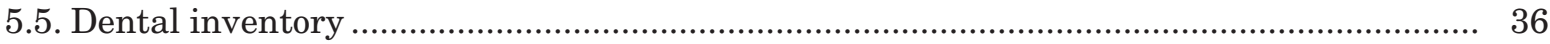

5.6. Nonspecific periosteal infection in the right ulna. Note the wider shaft in the

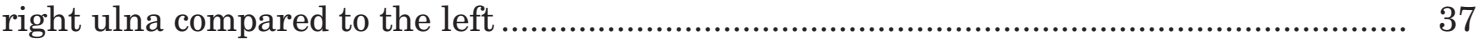

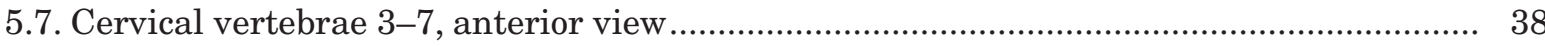


6.1. Leonard Nadel photographed this bracero grave along the railroad tracks near the Monterrey Processing Center in 1956

6.2. The front and back of the alien laborer identification card issued to Servando Panaloza Munoz on July 9, 1956.

6.3. Table of Mexican immigration statistics from an online publication of the Center for Immigration Studies. 


\section{LIST OF TABLES}

5.1. Skeletal analysis summary......

5.2. Sectioning points for sex estimation derived from modern Hispanic reference data 


\begin{abstract}
From 2011 through 2014, the Texas Department of Transportation collaborated with Prewitt and Associates, Inc., to investigate an isolated grave in a remote area alongside FM 481 in Maverick County, Texas. An initial archeological investigation confirmed that the location was a historic grave, and archival records revealed that it contained the remains of Salvador Camarena, a Mexican citizen who died in Texas in January 1950. Additional research identified Camarena's son and other family members living in Mexico, California, and Texas. With the family's permission, the burial remains were exhumed, examined, and reinterred at La Marque Cemetery in Galveston County, Texas, where Camarena's mother and two sisters are buried.

The bioarcheological analysis of the skeletal remains corroborates the historical information. Together, the bioarcheological and historical data provide a rare glimpse into the life and death of a migrant laborer. The burial of one immigrant worker may seem insignificant. However, the Camarena case represents a sad but common theme in the history of migrant labor. Like many before him and even more since, Camarena probably died in a foreign country seeking a means to support his family when traveling to seasonal agricultural work.
\end{abstract}

\title{
CURATION OF PROJECT RECORDS
}

No cultural materials were collected during this project. All of the skeletal remains and personal items associated with the Camarena burial were reinterred in the new grave. The digital photographs and paper records for this project will be submitted for permanent curation to the Texas Archeological Research Laboratory at the University of Texas at Austin. 


\section{ACKNOWLEDGMENTS}

First and foremost, we thank the family of the Salvador Camarena for their cooperation and involvement in this project. His son, Jesus ("Jess") Herrera Camarena provided us with information about his father and signed the legal paperwork authorizing TxDOT to exhume and reinter his father's grave. Mrs. Lilia Manriquez Flores, a niece of Salvador Camarena, was the only knowledgeable informant who recalled anything about her uncle. Interviews with Flores provided a great deal of important information, but she passed away soon after Camarena's remains were moved to the La Marque Cemetery and before this report was completed. We sincerely hope that the family knows his remains were treated with great care and respect when they were removed from Maverick County and reinterred near his relatives in La Marque, Texas.

This historical and bioarcheological project was a collaboration between researchers at the Archeological Studies Program, Environmental Affairs Division, Texas Department of Transportation (TxDOT-ASP), Prewitt and Associates, Inc. (PAI), and two consultants-Dr. Catrina Banks Whitley (Bioarchaeology Support, Midlothian, Texas) and Dr. M. Katherine Spradley (Department of Anthropology and Forensic Anthropology Center at Texas State University-San Marcos). The principal investigator for this project was Christopher Ringstaff (TxDOT-ASP), and Mark Denton was the project reviewer for the Archeology Division of the Texas Historical Commission. For TxDOT's Laredo District office, environmental coordinator Mike Graham was the liaison with the Eagle Pass maintenance office. He helped make all the local arrangements for the archeological investigations and assisted with the burial excavation.

Many people were involved with the archival and informant research to identify the gravesite, and in the subsequent bioarcheological investigations and reinterment of the burial remains. Preliminary research and initial field investigation of the gravesite was conducted by Ringstaff and Graham, and the initial archival research was done by Summer Chandler (TxDOT). PAI historian Amy E. Dase conducted more intensive archival research and tracked down and interviewed Camarena's descendants and relatives. Juan Valera-Lema (TxDOT) assisted with the Spanish language translations for the public notices that were sent out to local newspapers and churches. Whitley, assisted by Ringstaff, conducted the burial excavation and removal of the human remains and associated mortuary materials, and documented the burial with sketch maps, detailed notes, and digital photographs. Spradley conducted the osteological analysis, documenting the skeletal remains with detailed notes and photographs. Ringstaff documented and photographed the personal items accompanying the deceased. Waldo Troell (TxDOT-ASP) examined and described the wristwatch. Coordination for the reburial and purchase of the reburial plot at the La Marque Cemetery was done by Sharon Dornheim (TxDOT-ASP) and Ringstaff. James Crowder, Jr. handled the reintermment for the James Crowder Funeral Home. Ann M. Moreau, a colleague from Galveston, went to the La Marque Cemetery and photographed the new headstone at the reburial gravesite.

For PAI, this report was compiled by Boyd and edited by Elaine Robbins. Sandy Hannum and Brian Wootan created the illustrations. Rob Thrift prepared the project records for permanent curation. 


\title{
INTRODUCTION TO THE CAMARENA GRAVE PROJECT
}

1

\author{
Douglas K. Boyd and Christopher W. Ringstaff
}

\begin{abstract}
Next time I will cross over in the desert country. When, with companions, I will take a road through the desert sand where there are no people....it is hard, and, many die on such a road.

-Illegal migrant worker Quoted in the Los Angeles Times, May 2, 1950, as cited in Hernández (2006:439)
\end{abstract}

With millions of miles of roadways crisscrossing the state, the Texas Department of Transportation (TxDOT) faces a big challenge in dealing with historic graves inside state-owned rights of way. In some cases, roadways were unknowingly built over unmarked graves and cemeteries that had been abandoned and long forgotten. In other cases, old roadways were built over unmarked graves on the margins of known cemeteries. In still other cases, human remains were interred alongside unimproved roads but later got subsumed when roads were improved. This report deals with one specific case that falls into the latter category.

In January 1950, an immigrant Mexican laborer named Salvador Camarena was traveling through Maverick County, possibly going to or coming from a job in Texas. For reasons still unknown, he died in a remote area about 20 miles north of Eagle Pass (Figure 1.1). The decomposing body was found on January 17, 1950 , in a pasture close to a rural county road that was later widened and designated as FM 481. The discovery was reported to Maverick County officials, a death certificate was issued, and the remains were buried along the roadway the same day. Sometime later, between 1966 and 1983, when the roadway was expanded and paved, the grave was marked with an ironpipe fence and a cross with a plaque placed by family members. Written in Spanish, the plaque identified this location as the grave of Salvador Camarena.

Over the years, the grave became lost in people's memories. By 2010, the identifying plaque had disappeared, and local TxDOT officials no longer knew whose remains were buried in this roadside grave. Concerned that the iron fence and cross inside the FM 481 right of way was a safety hazard, officials in TxDOT's Laredo District office began asking what these features marked and if they could remove it. They contacted Christopher Ringstaff, an archeologist with TxDOT's Archeological Studies Branch in Austin. Ringstaff conducted an initial archeological investigation in January 2011 and confirmed that the location was a gravesite containing intact human skeletal remains. TxDOT then focused on identifying who was buried in the grave.

In September 2011, TxDOT personnel in Maverick County discovered some old photographs of the grave, presumed to be from the $1980 \mathrm{~s}$, and one showed the original name plaque that was once attached to the iron cross. The text on this plaque identified the person buried in the grave as Salvador Camarena. An online search by TxDOT researchers discovered a death certificate for Camarena, a Mexican citizen from Morelia, Mexico, who died in Maverick County in January 1950.

With a name now attached to the gravesite, TxDOT contracted with Prewitt and Associates, Inc. (PAI), a cultural resources firm in Austin, to begin looking for Camarena's relatives and to help TxDOT exhume and examine the burial remains, report the findings, and reinter the 


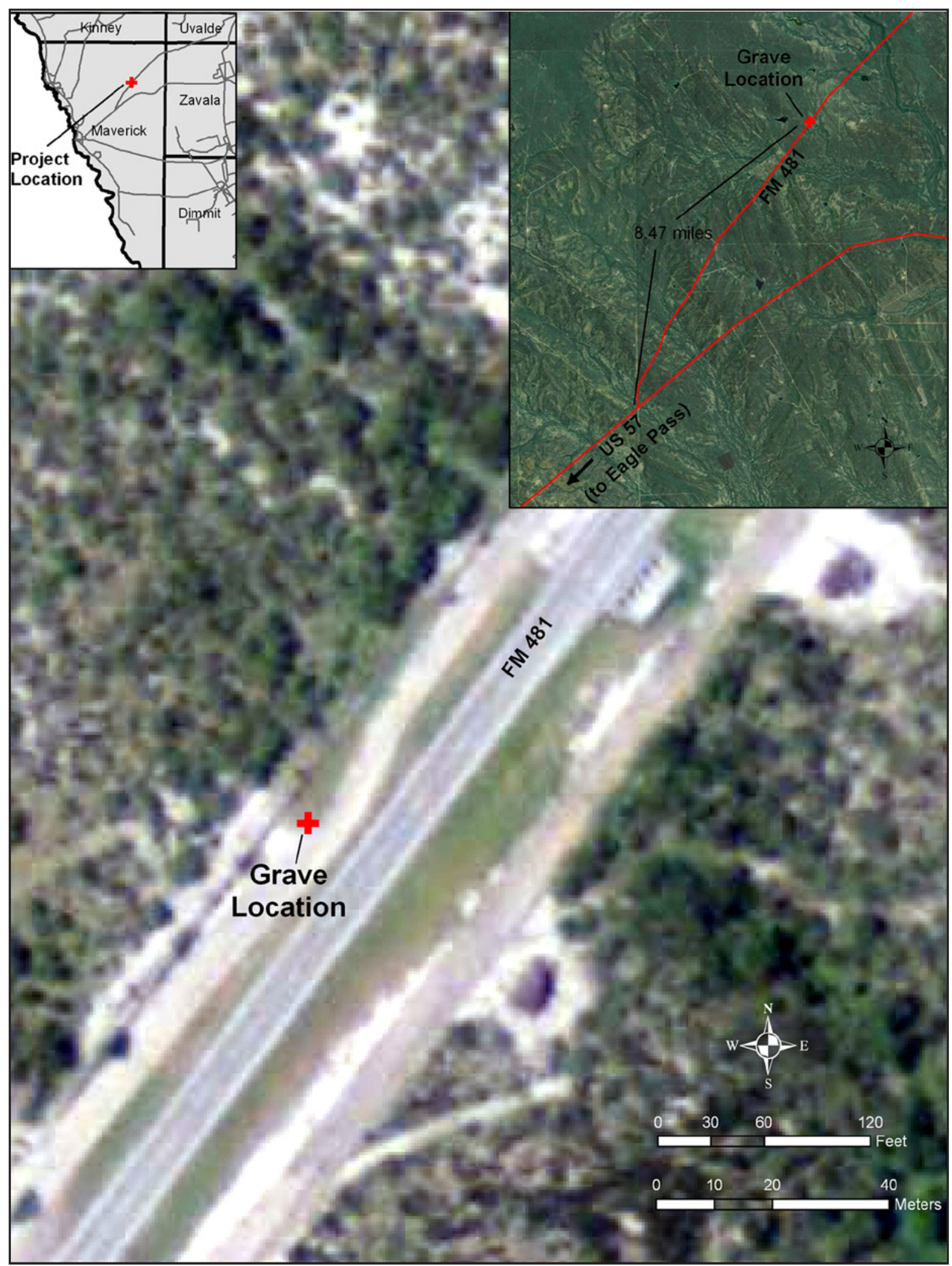

Figure 1.1. Map showing the location of the original Salvador Camarena gravesite along FM 481 in Maverick County, Texas. 
remains in a new location. Researchers successfully found Camarena's relatives. The grave was excavated in October 2012, and the burial remains were documented within two weeks. The remains were then transferred to a funeral home in La Marque, Texas, and reinterred in La Marque Cemetery.

This project was a collaborative effort between TxDOT's Laredo District office, TxDOT's Eagle Pass maintenance shop in Maverick County, TxDOT's Archeological Studies Branch in Austin, PAI, and two subcontractors, Dr. M. Katherine Spradley and Dr. Catrina Banks Whitley. ${ }^{1}$ In this report, we describe the entire investigative process and findings related to the Camarena grave. This includes the archival and oral history research, the archeological excavation of the historic burial, the bioarcheological analysis of the skeletal remains and associated personal items, and the reinterment of the

1 Prewitt and Associates' work was completed under two separate TxDOT Work Authorizations (Nos. 57108SA001 and 57309SA003) as part of TxDOT CSJ. No. 1590-03-965. The archeological investigation, bioarcheological analyses, and reinterment were authorized by Antiquities Permit No. 6043, issued to Christopher Ringstaff by the Archeology Division of the Texas Historical Commission. remains. All aspects of the prefield planning, archeological investigations, and reinterment followed Texas cemetery laws as defined in the Texas Health and Safety Code and the Antiquities Code of Texas. The presentation of this information is a mandated part of the archeological reporting process as defined by TxDOT and the Texas Historical Commission under the Antiquities Code.

Beyond the legally required reporting, a historical background with contextual information provides a foundation for understanding the life and death of Camarena. Camarena was an immigrant laborer who came to work in the United States regularly for many years and died on foreign soil in the mid-twentieth century. The complex history of migrant labor affected millions of Mexican nationals like Camarena who had limited choices when seeking employment across the border. 



\title{
HISTORICAL AND BIOARCHEOLOGICAL INVESTIGATIONS OF THE CAMARENA GRAVESITE
}

\author{
Christopher W. Ringstaff and Douglas K. Boyd
}

In August 2010 officials in the Laredo District office of the Texas Department of Transportation (TxDOT) contacted Environmental Affairs Division archeologists to express their concern about a roadside memorial in a remote area along FM 481 in northern Maverick County. They thought that the memorial, which consisted of a $9 \times 12-\mathrm{ft}$ iron-pipe fenced-in area, was a potentially dangerous obstruction that should be removed from the right of way (Figure 2.1). At the time, local TxDOT officials were not sure what the memorial was for. Inside the fence enclosure was a welded iron cross, suggesting that it might be a grave. But some people believed it commemorated someone who died at that location in an automobile accident along FM 481. Roadside memorials, called descansos (a "place of rest") in Spanish, are common in many parts of the southwestern United States. A descanso shrine usually commemorates the last place a person was alive before a fatal accident. Roadside memorials have become so popular across the country that most states must now regulate them so that they are not safety hazards. The Texas Department of Transportation (2013) recently updated its rules for "Memorial Markers Within the Right of Way." In the interest of public safety, it is the agency's policy to remove "hazardous and non-conforming markers" if possible.

This initial inquiry led to a long process of investigation that unfolded over a period of more than two years. The ultimate outcome of the research was the identification of the location as a human grave, the identification of the person buried in the grave as Salvador Camarena from Morelia, Mexico, and the discovery of relatives of the deceased living in the United States, including Camarena's son. Following this, an archeological excavation and analysis of the burial remains was completed with the family's permission, and the remains were reinterred in a Texas cemetery where other family members are buried. This rest of this chapter is a summary of this process (see Appendix A for a more detailed chronology of events).

\section{INITIAL INVESTIGATIONS}

On August 18, 2010, TxDOT's Laredo District office emailed archeologist Christopher Ringstaff (Archeological Studies Branch, Environmental Affairs Division) to find out what process they would need to follow to remove the safety hazard from the FM 481 right of way. Ringstaff informed the district that because no one knew for sure if the object was a grave marker, its removal required an entirely different process than if it were known to be a simple roadside memorial. The Laredo District and Ringstaff initiated research to find out if the location was indeed a grave.

In November 2010, the district received conflicting information. One local informant believed that the location was a grave, and another believed it was a roadside memorial for two people killed in an automobile accident. In December 2010, however, Ringstaff reviewed a 1974 topographic map that marked the location with a cross and the word "Graves" (Figure 2.2). This provided strong circumstantial evidence that the iron fence probably marked the location of a burial. The research then switched from finding out about the marker to finding out if human remains were buried there. 


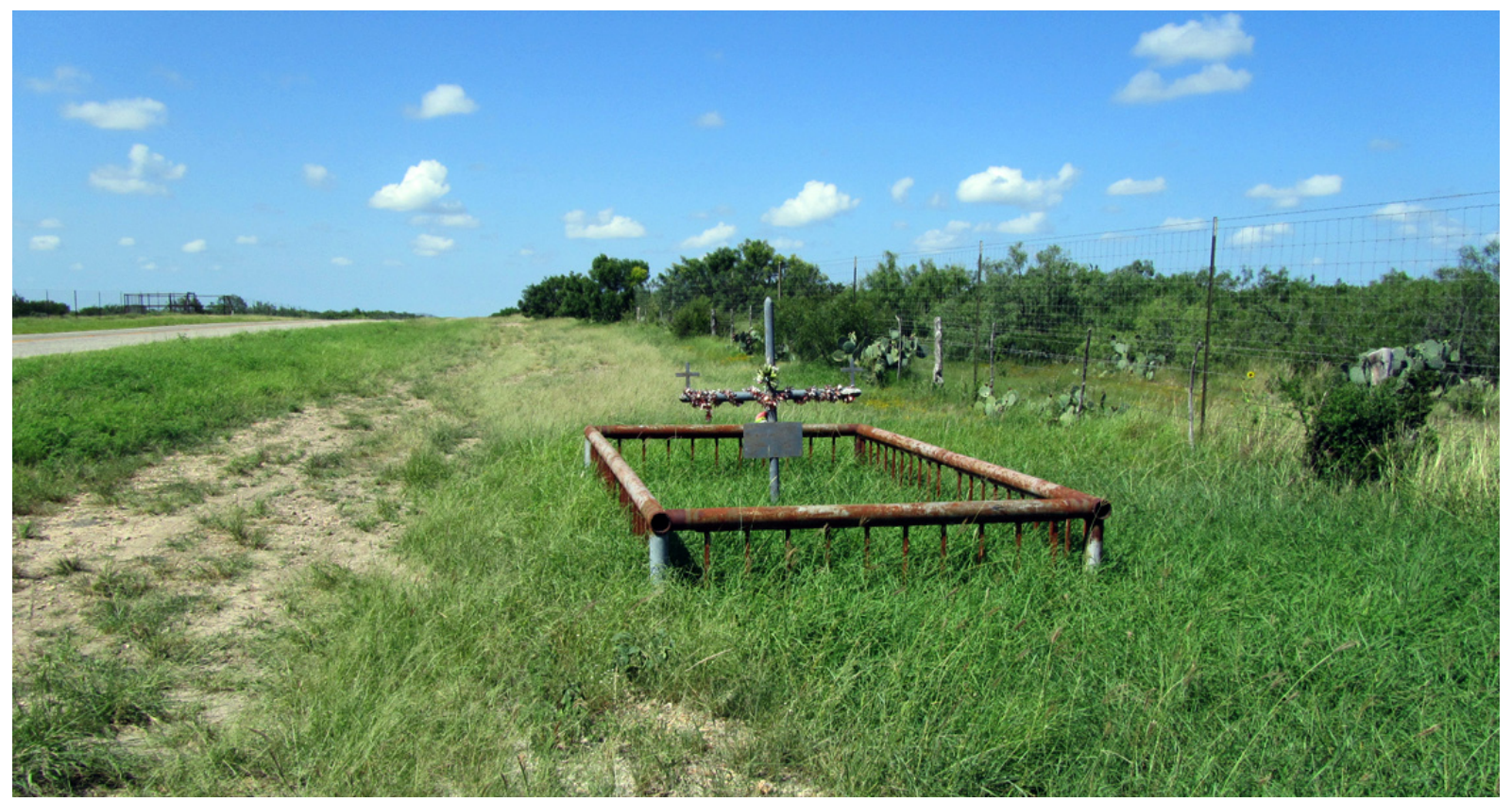

Figure 2.1. Photograph of the gravesite taken on July 19, 2010. Photograph courtesy of TxDOT Laredo District.

On January 17, 2011, Ringstaff conducted a survey of the possible gravesite to determine if one or more human graves were enclosed within the iron fenced area. A Gradall was used to remove the fence and iron cross and then to carefully scrape the surface to look for evidence of graves, such as sediment changes indicative of intrusive grave shafts (Figures 2.3 and 2.4). In cases where no grave shaft is evident, scraping may reveal evidence of burial containers, such as wood or handles from coffins or caskets, or may uncover human skeletal remains. This initial investigation was authorized by TxDOT's Memorandum of Understanding with the Texas Historical Commission.

Ringstaff discovered evidence that the location was a human grave. No sediment changes were observed to indicate a grave shaft, and no evidence of a burial container was found. But the Gradall scraping uncovered human foot bones and a shoe sole, providing evidence of a shallowly buried grave. The grave was then backfilled with sediment to cover and protect the remains (Figure 2.5).

After returning to Austin, Ringstaff (2011) completed an interim report on the initial investigation and submitted it to THC on February 2, 2011. He made the following conclusions and recommendations:
- In situ human remains were found, confirming that the location was a gravesite. All excavations were halted, and the shallowly buried grave was covered to protect it.

- The gravesite meets the definition of an "Abandoned Cemetery" and a "Marked Grave" as defined in 13 TAC §22.1(1) and 13 TAC $\$ 22.1(8)$ of the Texas Administrative Code.

- TxDOT would file a "Notice of Existence of Cemetery Form" with the Maverick County, Clerk, as required by 13 TAC $\$ 22.4(\mathrm{a})$ of the Texas Administrative Code.

- TxDOT recommended placing public notices in local newspapers and conducting additional research "to ascertain, if possible, the identity of the individual(s) within the abandoned cemetery."

- All work relating to the burial relocation would be conducted in strict adherence with all pertinent provisions in the Health and Safety Code (Chapters 711 and 712) and the Texas Administrative Code (13 TAC $\S 22)$.

Over the next eight months, TxDOT conducted research to learn more about the marked 


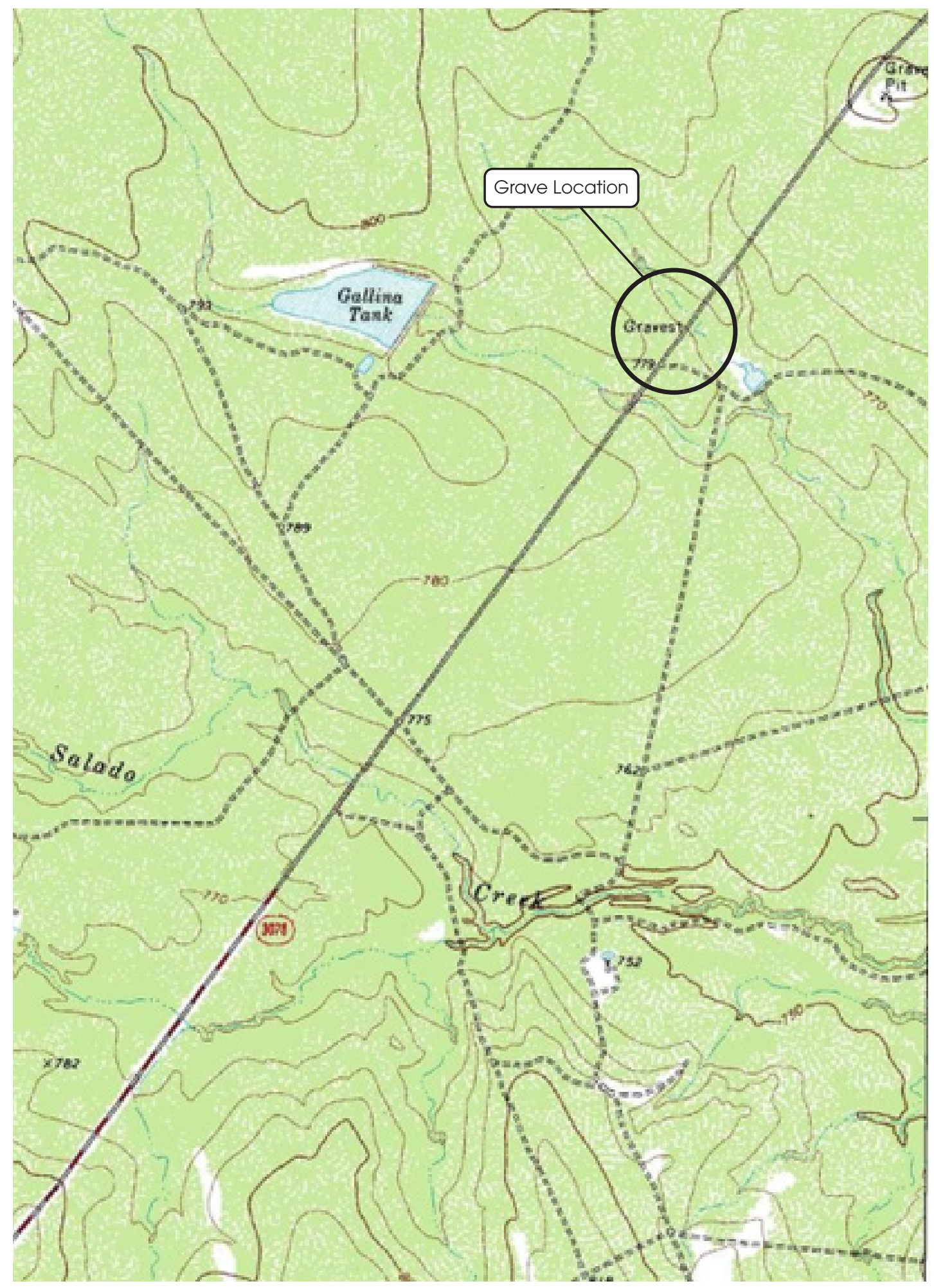

PAI/14/BW

Figure 2.2. Location of the Camarena gravesite as shown on the USGS 1974 Trosado Tank Quadrangle (7.5 minute). The site marked is on the west side of an unpaved section of FM 3078, which later was renamed FM 481. 


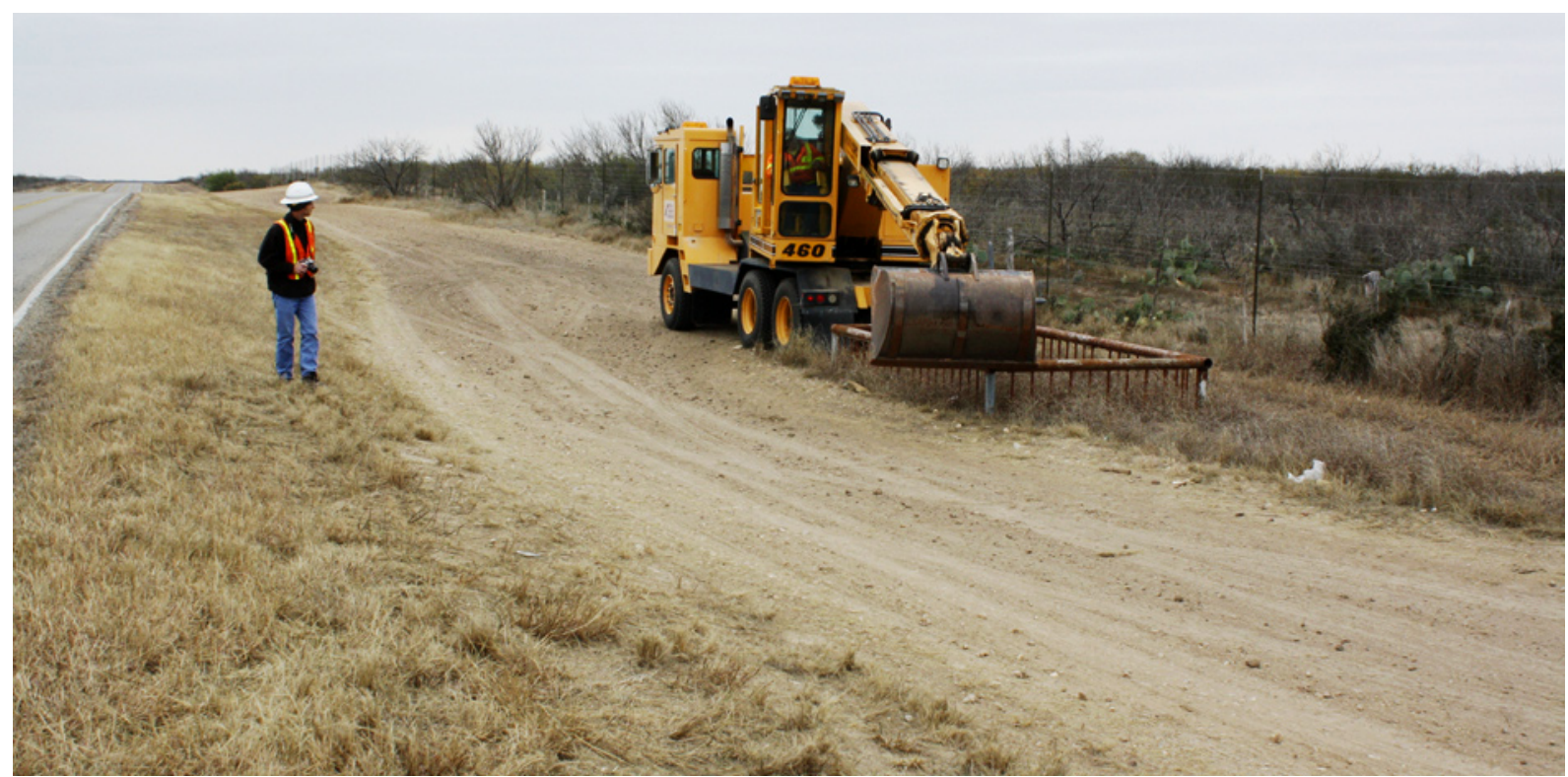

Figure 2.3. Photograph of the Gradall lifting the iron fence to remove it prior to the mechanical grave search on January 17, 2011.

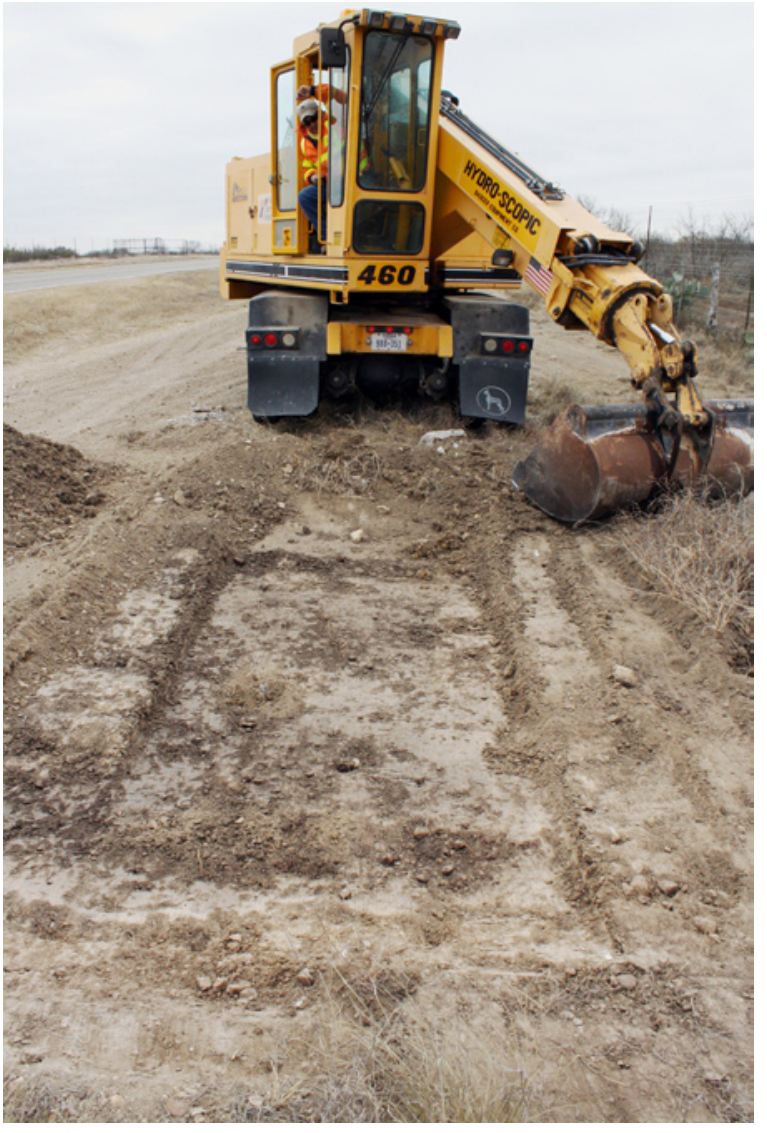

a

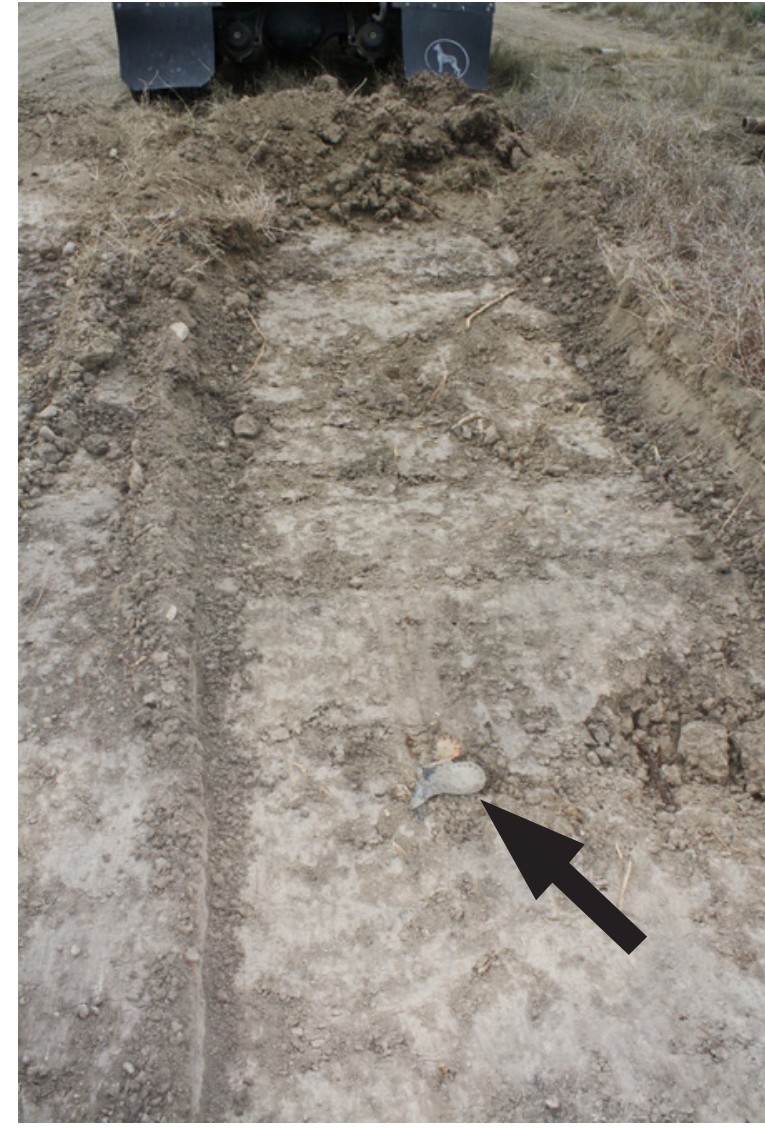

$\mathrm{b}$

Figure 2.4. Photographs of Gradall scraping at the gravesite on January 17, 2011. (a) Overview of scraping at approximately $10 \mathrm{~cm}$ below surface; (b) closeup of scraping at $25-30 \mathrm{~cm}$ below surface. The arrow marks an in situ shoe heel. 

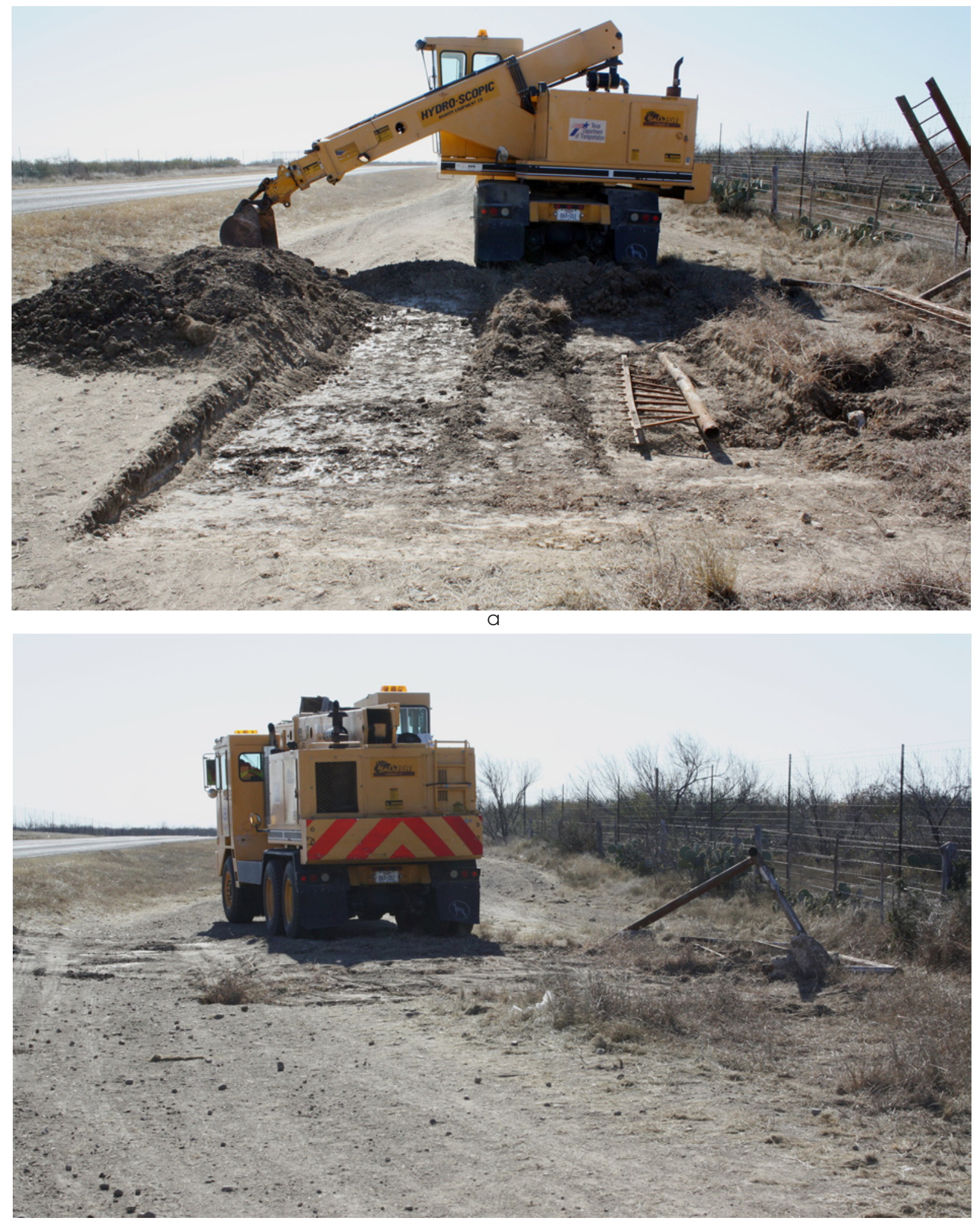

b

Figure 2.5. Photographs of Gradall backfilling at the gravesite. (a) Overview of backfilling in progress, with a portion of the iron grave fence placed over the grave for protection; (b) gravesite completely backfilled. 
grave in the FM 481 right of way. Letters asking for any information on the grave were sent to people who owned property in the vicinity of the grave and to local churches. TxDOT got few responses, and most of the people who did respond thought that the location was a roadside fatality marker. Only the owner of the adjacent property knew that the location was a grave. Charles Roswell responded that the grave was originally on his family's property but got subsumed into the state-owned right of way because of the 1980s road expansion. Roswell knew that the person buried in the grave was a migrant worker from Mexico, but he did not know the person's identity.

Two breakthroughs in the research came in the fall of 2011. On September 29, TxDOT workers in the Eagle Pass Maintenance Office discovered a "Polacolor" (Polaroid) photograph of the grave fence and marker showing an iron plaque welded onto the cross. An inscription was handwritten on the back of the print (Figure 2.6). Written in Spanish, the transcribed text of this memorial plaque read: "Salvador Camarena, dedican este recuerdo sus hermanas, Maria y Margarita, y su esposa e hijos, Eagle Pass, Texas." This translates to "Salvador Camarena, dedicated as a remembrance by his sisters, Maria and Margarita, and his wife and kids, Eagle Pass, Texas." This photograph provided conclusive evidence identifying the gravesite as that of Mr. Salvador Camarena. It dates sometime after the 1963 introduction of Polacolor instant print film by the Polaroid Corporation (Boston University 2014). A local highway department worker probably took the photograph between 1966 and 1983 when the road underwent improvements.

Following up on this lead on October 17, 2011, TxDOT architectural historian Summer Chandler (Historical Studies Branch, Environmental Affairs Division, Austin) conducted online research and located an official Texas death certificate for Camarena (see Chapter 3 ). The certificate indicates that the body was found in "Galinas Pasture" January 17, 1950, but it had been exposed for about 10 to 15 days, which meant that the death occurred in early January. Galinas Pasture corresponds with the "Gallina Tank," a stock tank that appears on the 1974 topographic map (see Figure 2.2). Gallina Tank is less than 1 mile west of the gravesite. Chandler also found evidence that Camarena had relatives living in both the United States and Mexico based on the countries' 1930 federal population censuses (see Chapter 3).

In late October 2011, TxDOT placed public notices in local newspapers seeking information on Salvador Camarena. The notices appeared in The News Gram in Eagle Pass and The Galveston County Daily News, the largest newspaper serving the Texas City area.

\section{PREWITT AND ASSOCIATES INVOLVEMENT}

As of October 2011, TxDOT determined that it would need assistance with the historical research pertaining to the Camarena gravesite. In January 2012, TxDOT issued a work authorization to Prewitt and Associates, Inc. (PAI). ${ }^{2} \mathrm{As}$ one of TxDOT's cultural resources contractors, PAI was brought on to conduct more in-depth genealogical research pertaining to Camarena, to locate living relatives of the deceased, and to provide assistance with analysis of the human skeletal remains. The remainder of the project, including archival research, informant interviews, and bioarcheological studies, became a collaborative effort involving TxDOT, PAI, and PAI's consultants. TxDOT issued a second work authorization in October 2012 for PAI to provide a physical anthropologist to assist them with the field excavation of the gravesite and recovery of the burial remains. ${ }^{3}$

PAI historian Amy Dase began conducting genealogical research on the Camarena family, and in February 2012 she identified several of Salvador Camarena's relatives. She talked with Jesus "Jess" Herrera Camarena, who resides in Redding, California, who confirmed that he was the son of Salvador Camarena. When Camarena was informed of TxDOT's plan to exhume the grave and move the burial remains, he requested that his father's remains be reburied in La Marque Cemetery in Galveston County, where the graves of several other family members are located. TxDOT immediately began planning for the archeological excavation at the burial site and the reinterment as requested by the family. On May 28, 2012, Jesus Camarena signed the next-of-kin consent form authorizing the exhumation and reinterment of his father's remains.

\footnotetext{
2 Work Authorization No. 57108SA001 was issued on January 25, 2012.

3 Work Authorization No. 57309SA003 was issued on October 5, 2012.
} 

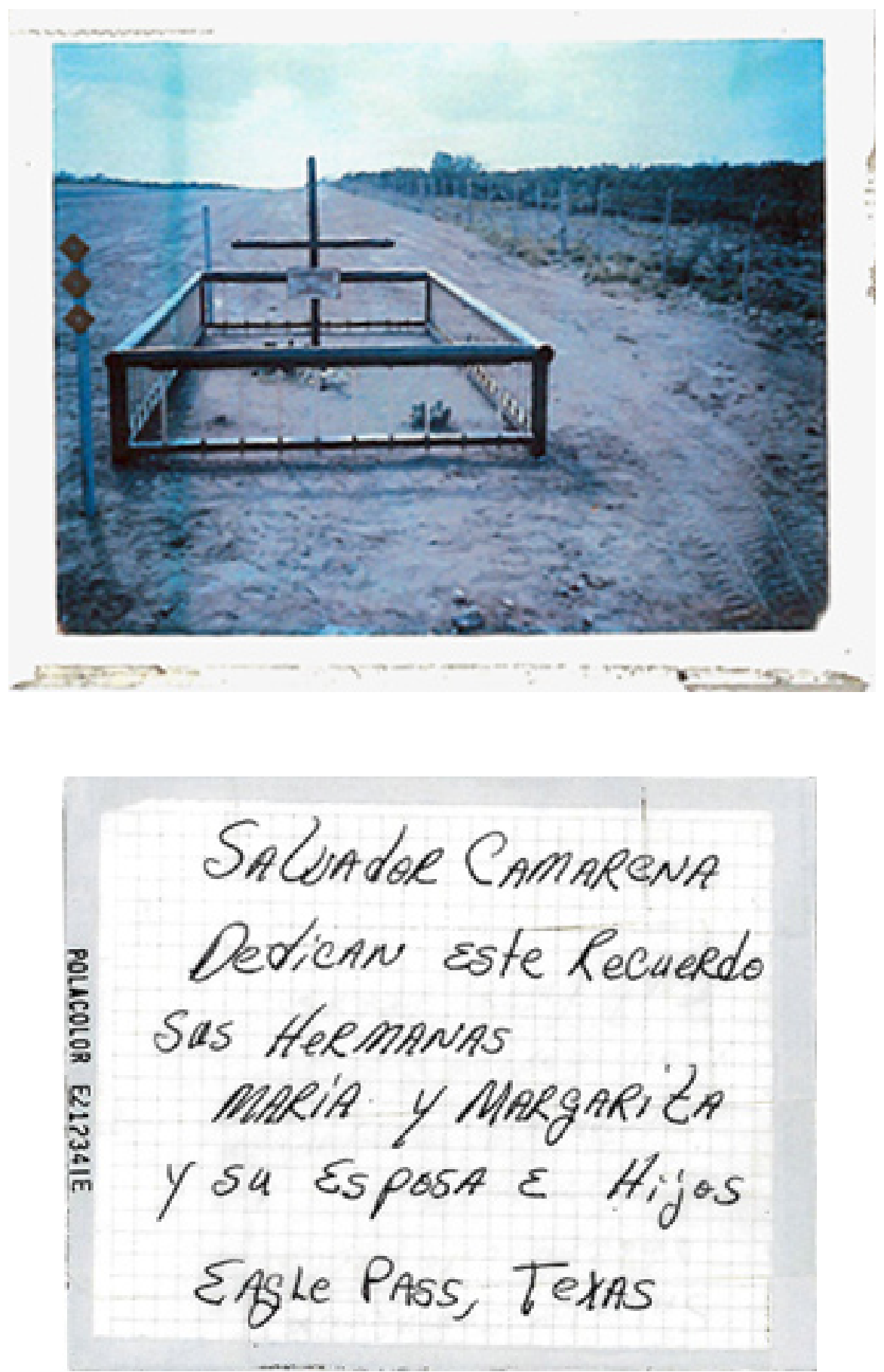

Figure 2.6. Polacolor photograph of the iron fence and cross marking the grave of Salvador Camarena, and the Spanish inscription handwritten on the back of the print. Original photograph on file at TxDOT's Eagle Pass Maintenance Office.

In June 2014, a cemetery plot was reserved in La Marque Cemetery for the reburial, and the purchase was completed about four months later. That summer TxDOT worked with state attorneys to draft a court order for the removal of the grave, and a Maverick County judge signed this document on August 22, 2012. On September 21, 2012, TxDOT received a disinterment permit for the exhumation from the Department of State Health Services. 
By the end of September 2012, all of the legal paperwork authorizing the grave exhumation was in place, and planning for the next step began. On October 10-11, 2012, Ringstaff and Dr. Catrina Banks Whitley, a consultant for PAI, conducted the excavation and bioarcheological examination of the Camarena grave. This work is detailed in Chapter 4. During the excavation, the iron-pipe cross that had marked the grave was placed nearby along the western edge of the right of way, where it will serve as a memorial marker for the former gravesite (Figure 2.7).
Immediately following the burial excavation, TxDOT archeologists photographed and examined the personal items interred in the grave, and the skeletal remains were transported to the Anthropology Department at Texas State University in San Marcos. Dr. M. Katherine Spradley then conducted a detailed osteological analysis of the skeleton to determine the age, sex, pathology, biological affinity, and other attributes. The methods and findings for this study are described in Chapter 5 and Appendix B. After completion of the osteological analysis, TxDOT

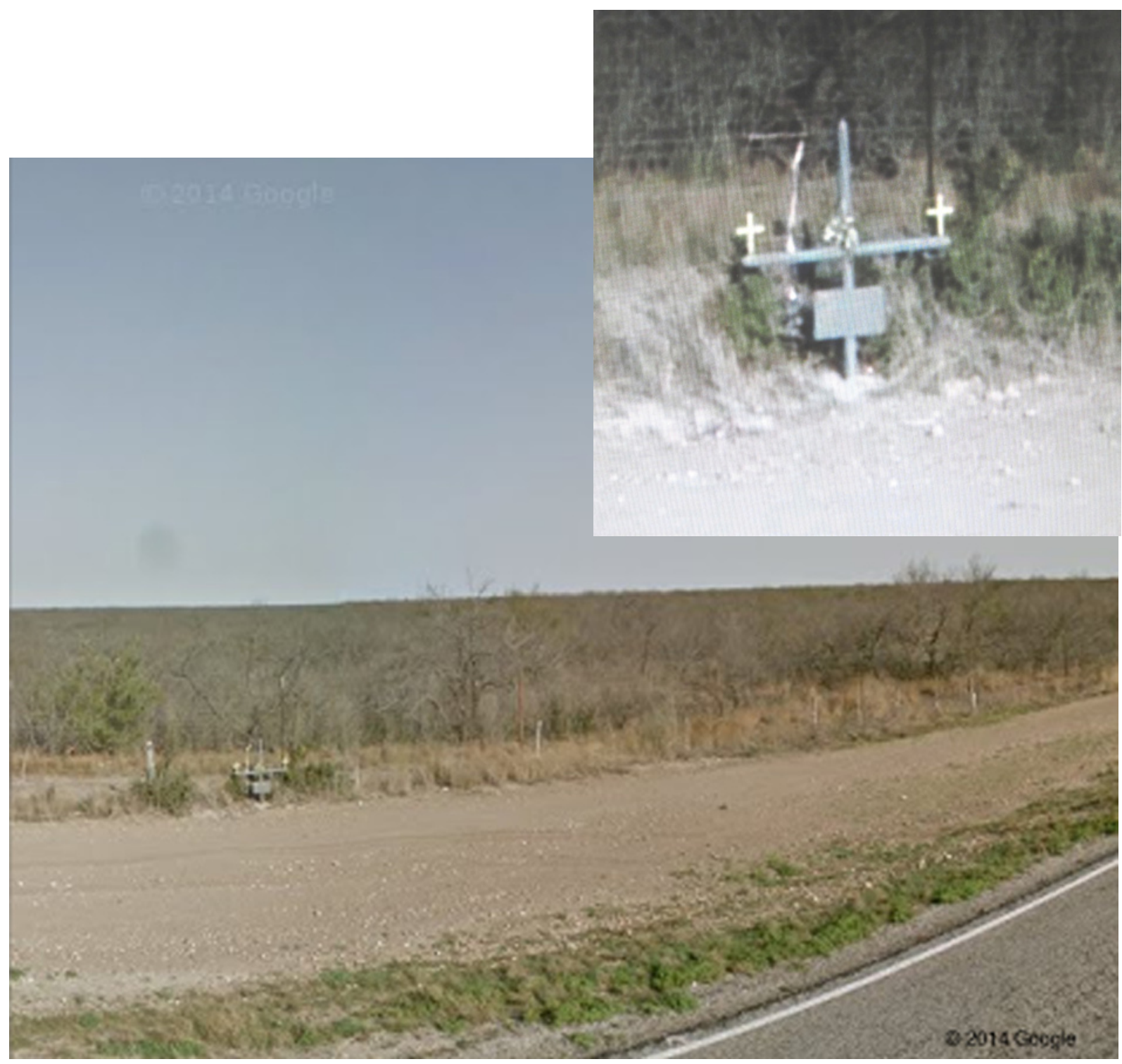

Figure 2.7. The iron-pipe cross that originally marked the Camarena grave was repainted and placed along the west edge of the right of way. Primary view is to the northwest, and inset view is to the west. Photographs are from Google Maps "Street View” and were taken in February 2013. 
transported the Camarena burial remains to La Marque, Texas, on October 24, where they were turned over to the James Crowder Funeral Home to await reburial. Information on the original Camarena gravesite was filed with the Texas Archeological Research Laboratory, and the location was assigned the permanent archeological site number of 41MV372.

\section{REINTERMENT}

Salvador Camarena's burial remains were reinterred on October 26, 2012, at the La Marque Cemetery in Galveston County, Texas. The reburial was conducted courtesy of the James Crowder Funeral Home (401 Texas Avenue in La Marque, Texas). The reburial plot (Space 9, Lot 133 , in the southeast quad) is near the grave of Maria Camarena Pena, who was Salvador Camarena's sister. According to the headstone, Maria C. Pena lived from December 27, 1909, to January 17, 1999. Another of Salvador Camarena's sisters, Margarita Camarena de Manriquez, who lived from June 10, 1898, to September 30,1982, is also buried nearby in the La Marque Cemetery.

Salvador Camarena's niece, Lilia Manriquez Flores, attended the reburial event, along with Mr. James Crowder, Jr. of the James Crowder Funeral Home. A new headstone was placed at the gravesite. The inscription reads, "In Loving Memory/Salvador Camarena/1895/JAN. 17, 1950" (Figure 2.8). ${ }^{4}$ Not long after the reinterment, Jesus Herrera Camarena visited his father's gravesite during a trip to visit relatives in La Marque.

\footnotetext{
4 The dates on the new headstone do not agree with the documentary evidence. Most records indicate that Salvador Camarena was born about 1897 and died in early January 1950, at least 10 days before his body was found on January 17.
} 


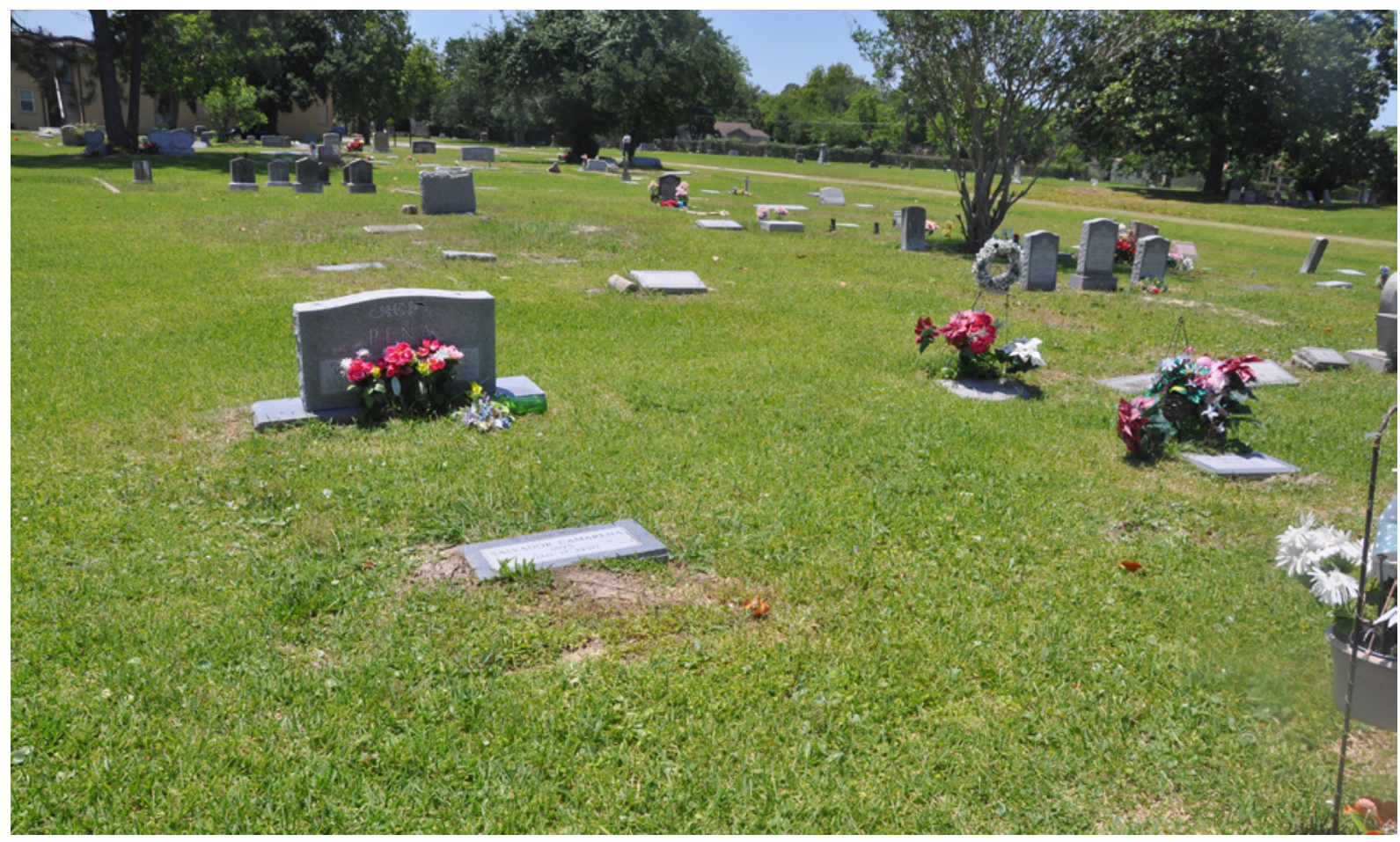

a

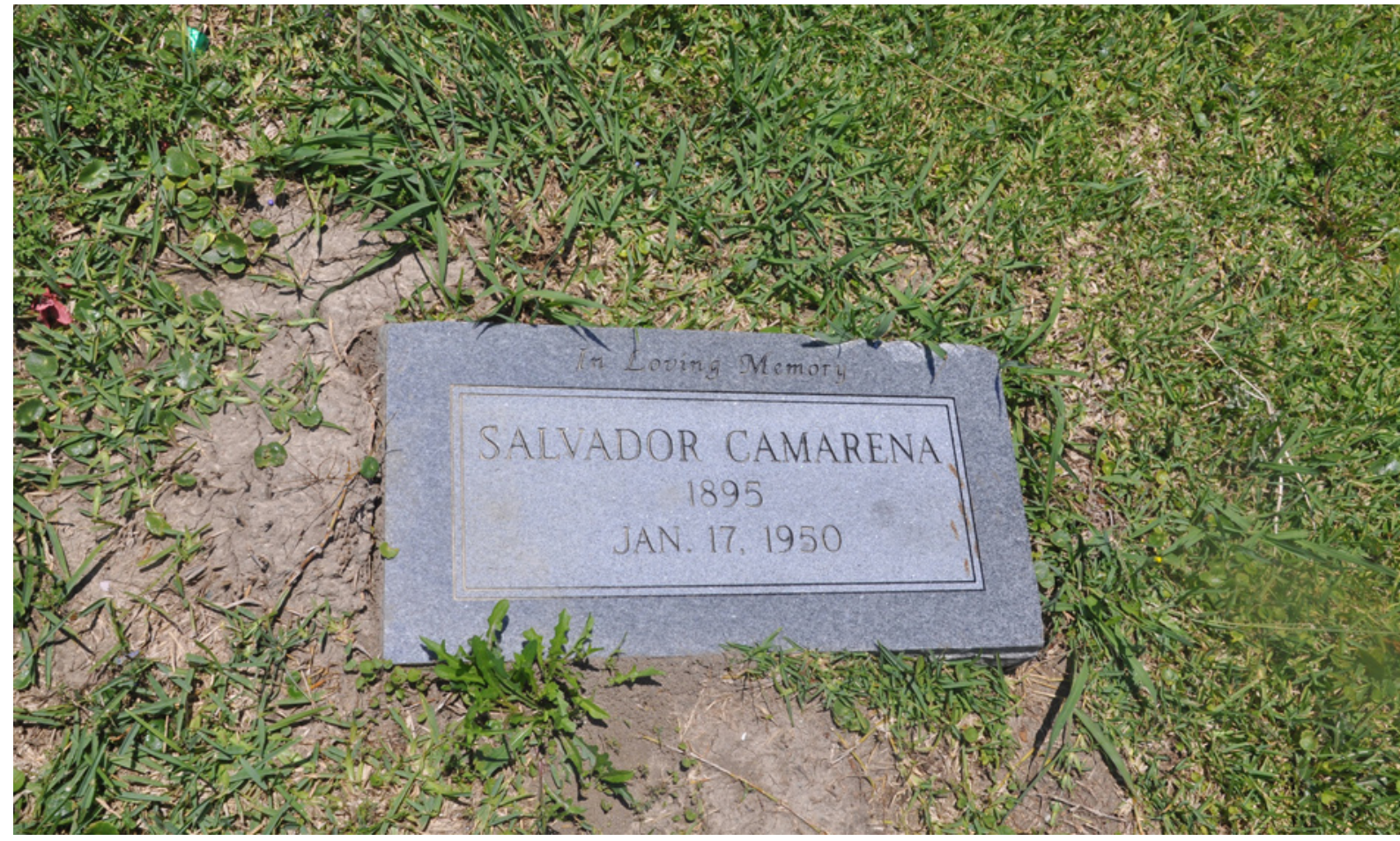

b

Figure 2.8. Photographs of the new headstone marking the reinterment grave of Salvador Camarena in the La Marque Cemetery. (a) Overview showing Salvador Camarena's headstone in foreground with the headstone of his sister, Maria C. Pena, and brother-in-law, Rogue V. Pena, directly behind. (b) Closeup view of Salvador Camarena's headstone. Photographs by Ann Moreau. 


\section{HISTORY OF SALVADOR CAMARENA (1897-1950) AND THE SEARCH FOR RELATIVES}

2

Amy E. Dase

\section{RESEARCH METHODOLOGY}

Personnel from TxDOT provided the following documents to PAI related to the grave and the decedent, Salvador Camarena:

- an undated handwritten transcription of Spanish text from a metal plate affixed to a 6-ft-tall welded metal cross at the grave (Texas Department of Transportation, Eagle Pass Maintenance Office n.d.);

- an August 22, 1928, manifest record for Salvador Camarena (U.S. Immigration and Naturalization Service, U.S. Department of Justice 1928);

- a 1930 Mexican federal manuscript census record for Salvador Camarena, one of his sisters, and his mother (E.U. Mexicano, Departmento de la Estadistica Nacional, Direccion de Censos 1930);

- a 1930 United States federal manuscript census record for Margarita Camarena Manriquez, another of Salvador Camarena's sisters, living on Texas Avenue in Galveston (U.S. Department of Commerce, Bureau of the Census 1930); and

- a January 17, 1950, certificate of death for Salvador Camarena from the Texas Department of State Health Services, Vital Statistics Unit (Texas Department of State Health Services, Vital Statistics Unit 1950) (Figure 3.1).

Based on information provided in these documents, archival research was conducted to locate Salvador Camarena's surviving next of kin, which was presumed to be a difficult assignment that would require a substantial amount of time. It was unknown if surviving relatives resided in Mexico or if they remained stateside. However, with only minimal additional archival and informant research, the task was accomplished. A search for Margarita Camarena Manriquez, one of Salvador Camarena's sisters, led to her grave at La Marque Cemetery in Galveston County, Texas. Her 1982 obituary listed several relatives, including a son and a daughter (Find A Grave 2012; The Galveston Daily News 1982). Accurate addresses for each relative named in the obituary were obtained from county appraisal district records and address directories.

A brief statement explaining the situation and requesting assistance in determining Camarena's next of kin was mailed to five relatives named in Margarita Camarena Manriquez's obituary: her daughter (niece to Camarena) Lilia Manriquez Flores, who had both a post office box and a street address in Texas City; and four of her grandchildren (grandnieces and stepgrandnephew to Camarena), Anita C. Pena Melchor and Minerva Gomez of Houston, Elsie Flores Garibay of Metairie, Louisiana, and Roque V. Pena Jr. of Sour Lake, Texas. Her daughter responded immediately and provided extensive information in a February 24, 2012, telephone call. She said that she had visited Camarena's roadside grave with her mother and recalled its rural setting. The most valuable information she provided was that her uncle had a son named Jesus Herrera Camarena, known as Jess, who immigrated from Mexico shortly after his father's death and lived with her parents in Texas City in his youth. She was uncertain as to his where- 


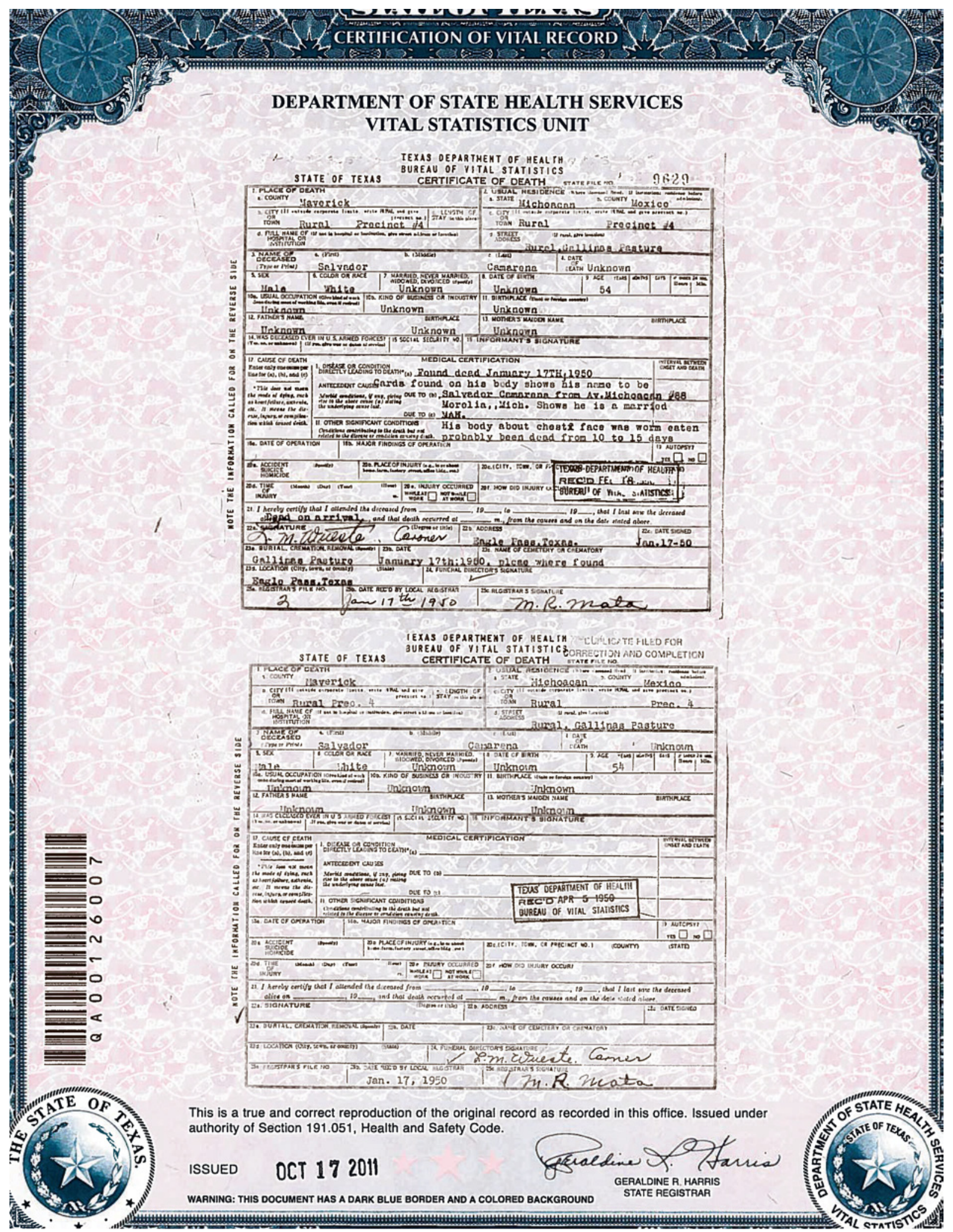

Figure 3.1. The certificate of death for Salvador Camarena. 
abouts after he graduated from high school and left Texas City. She relayed that her uncle had other children who were probably in Mexico, and that three relatives-Camarena's mother, Maria Ramirez, and his sisters, Margarita Camarena Manriquez and Maria Camarena Pena-were buried in La Marque Cemetery (Lilia Manriquez Flores, personal communication 2012). Garibay and Melchor also responded but provided no additional details (Elsie Flores Garibay, personal communication 2012; Anita C. Pena Melchor, personal communication 2012).

The focus of archival research turned to locating Jesus "Jess" Herrera Camarena. A March 31, 1951, manifest record for the eightyear-old boy reported the widowed Maria Herrera Camarena as his mother and the deceased Salvador Camarena as his father (U.S. Immigration and Naturalization Service, U.S. Department of Justice 1951). Further inquiry revealed that Jesus Herrera Camarena petitioned for naturalization in Honolulu on September 2, 1970 (U.S. Immigration and Naturalization Service, U.S. Department of Justice 1970). Related searches indicated that he had married and resided in one of several locations in California. A telephone directory provided two numbers with northern California area codes. One of these numbers was active, and a telephone conversation on February 27, 2012, with Jess Camarena, who resided in Redding, California, confirmed that he is the son of Salvador Camarena and Maria Herrera Camarena. He knew of his father's roadside grave in Maverick County, Texas, and that his mother had died in 1984. He noted that he had three deceased sisters and one surviving sister who lives in Morelia, Mexico. He said that he would attempt to contact her. PAI provided him with contact information for his cousin Lilia Manriquez Flores so they could become reacquainted (Jess Camarena, personal communication 2012). At this point, research efforts to find Salvador Camarena's closest next of kin concluded.

\section{RESULTS OF ARCHIVAL AND INFORMANT RESEARCH}

It remains unknown which direction Camarena was traveling when he died in January 1950. He may have been on his way to work or visit relatives in Texas, or he may have been returning to Mexico and work or family there. His cause of death was and remains unknown, but possibilities include complications from a medical condition he had been diagnosed with in 1928, or a snake bite. ${ }^{5}$ Exposure to severe cold may have also been the cause, or may have hastened his death since, between January 4 and 6 that year, high temperatures in the area were barely above freezing, and lows dipped into the mid teens with fog and precipitation that included snow or ice pellets (Farmers' Almanac 1950a, 1950b, 1950c). An identification card he carried at the time of his death indicated that he was married and had resided at 88 Avenue Michoacán, Morelia, Michoacán de Ocampo, Mexico (Texas Department of State Health Services, Vital Statistics Unit 1950; Texas Department of Transportation, Environmental Affairs Division, Archeological Studies Branch n.d.).

Much remains unknown about Camarena's original grave. It is unclear who dug the roadside burial. It was initially on privately owned ranchland near the road. By 1957, the county road had a bituminous surface near the grave, but much of the route was bladed earth (Texas State Highway Department 1961) (Figure 3.2). The state highway department acquired the right of way in 1966, when the road came on system as RM 3078. The route was redesignated FM 3078 in 1978, and again redesignated as FM 481 in 1983 (Texas Department of Transportation $2014 \mathrm{a}, 2014 \mathrm{~b})$. Improvements to the road likely occurred during this time span, such as paving, bridge and culvert construction, and standard signage installation.

It is also unknown when the fence-a $9 \times 12$ $\mathrm{ft}$ welded 4-inch-diameter steel-pipe fence with a concrete base-and memorial were added, but these features were added between 1966 and 1983 (Texas Department of Transportation, Environmental Affairs Division, Archeological Studies Branch n.d.). It is likely that workers from the Chittim gas field, a few miles southwest of the grave, made the fence, according to the rancher whose land is now adjacent to the site (Charles Roswell, personal communication 2014). The gas field and a worker camp have been present since at least 1959 (U.S.

\footnotetext{
5 This is an unsubstantiated rumor. Lilia Manriquez Flores remembered that someone in the family had said that her uncle might have died of a snakebite (James Crowder, Jr., personal communication 2014).
} 


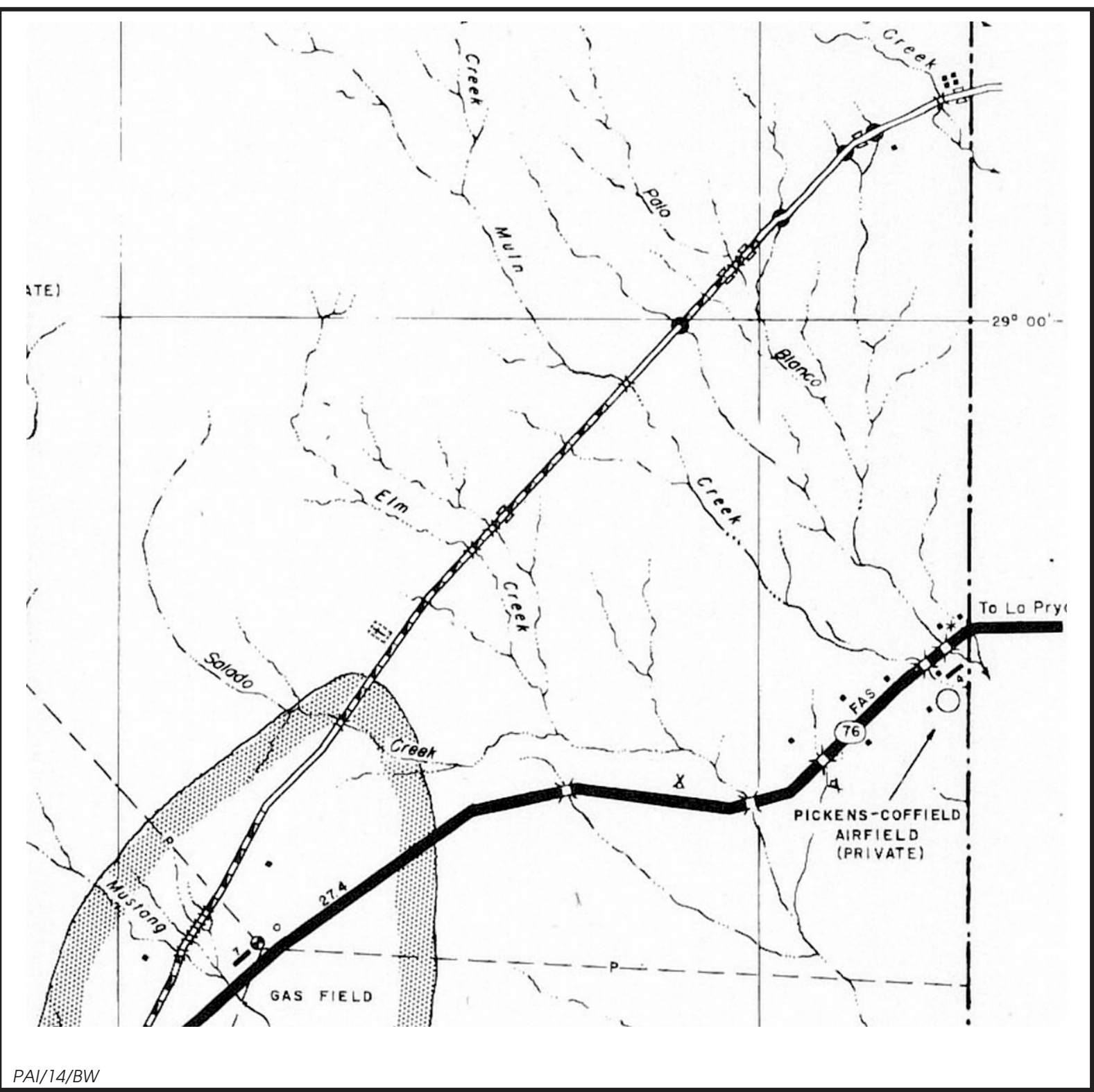

Figure 3.2. Section of a 1961 Maverick County map showing the location of a grave along the county road between Elm and Salado Creeks.

Department of the Interior, Geological Survey 1959). A metal plaque with Spanish text affixed to the cross identified Salvador Camarena (see Chapter 2). The presence of the memorial and its specific details indicate that Camarena's family was notified of his death and the location of his grave, but it remains unknown when this occurred and who made the contact.

Only a little is known about Camarena's life. He was born to Maria Ramirez (ca. 1866-1946) and Francisco Camarena in about 1897, possibly in Yuriria or Morelia (Texas
Department of State Health Services, Vital Statistics Unit 1946, 1950; U.S. Immigration and Naturalization Service, U.S. Department of Justice 1928; Jess Camarena, personal communication 2014). Little is known of his earliest years. Hehad at least one older brother, Joaquin; a younger brother, Jesus; and two younger sisters, Margarita and Maria (E.U. Mexicano, Departmento de la Estadistica Nacional, Direccion de Censos 1930; Texas Department of Transportation, Environmental Affairs Division, Archeological Studies Branch 
n.d.; U.S. Immigration and Naturalization Service, U.S. Department of Justice 1924a, 1924b; U.S. Selective Service System 1918). Camarena was working for the shoe manufacturing company Selz, Schwab \& Company in Chicago in 1918, when he registered at the West Augusta Boulevard location for the World War I draft (U.S. Selective Service System 1918). Usually registration occurred at the draft board office closest to the registrant's home, but in 1910 and 1920, this area had no heads of household of Mexican descent (U.S. Department of Commerce, Bureau of the Census 1920a). More likely, the office was convenient to the shoe factory, which was just a few blocks east of the draft board office, at the northwest corner of North Kingsbury and West Superior Streets (Shoe and Leather Reporter 1921:41). Because digital military service records are not available, it remains unclear whether Camarena served during the war.

In August 1928, Salvador Camarena, now in his early thirties, crossed the border by himself at Brownsville as a laborer. He had traveled from Mexico City and was headed for Texas City to stay with his brother-in-law and sister, Abram (sometimes referred as Abraham or Abran) and Margarita Camarena Manriquez. By this time, Camarena had contracted gonorrhea and had two large pit scars on his right forearm or forehead (the writing on his manifest card is difficult to decipher) (U.S. Immigration and Naturalization Service, U.S. Department of Justice 1928). He was back in his birthplace by 1930 . That year, he resided at 49 Avenue Ocampo in Morelia with his widowed 55-yearold mother, Maria Ramirez, and his 20-year-old sister, Maria Camarena. Both he and his sister were single at the time. They resided in either a single- or multiple-family dwelling with the Chavez family, which included eight people. Camarena was employed as a cargador, a loader or dockworker (E.U. Mexicano, Departmento de la Estadistica Nacional, Direccion de Censos 1930). He married Maria Herrera Ramirez in Morelia (U.S. Immigration and Naturalization Service, U.S. Department of Justice 1951). She was a schoolteacher before their marriage. After marrying, the couple had a retail business that followed the fiesta circuit (Jess Camarena, personal communication 2014). By the mid-1940s, the couple had five surviving children, all born in Morelia: Delia, Eliasar, Jesus, Margarita, and
Rosalinda. Jesus, later known as Jess, their only son, was born on April 29, 1942 (Jess Camarena, personal communication 2012; U.S. Immigration and Naturalization Service, U.S. Department of Justice 1951).

Jess Camarena had limited recollections about his early family life. He recalled traveling on trains between towns and little time at home until he was enrolled in school. He was industrious when he was young, and often skipped school to make spending money at the train station. His mother discovered his absences and enrolled him in a Catholic school that would be stricter about truancy. The only clear recollection of his father was on the celebration of Diez y Seis, or Independence Day, when the young boy was sent to get flags. Stopping to watch the parade, he returned too late for the flags to be relevant, and his father thrashed him. Not unlike other local men, his father had a second wife and large family that lived in Morelia. His mother wanted him to meet these half siblings so he would know his "extended" family. However, circumstances of his young life brought him to Texas, and he lost contact with his family of origin (Jess Camarena, personal communication 2014).

It remains unclear how often or how long Salvador Camarena had been in Texas, but he had family ties in Texas City by 1930 . His sister Margarita (1898-1982) immigrated to Texas through the Hidalgo crossing in March 1919 with her husband, Abram Manriquez (1892-1959). In 1920, the Manriquezes rented a house in Erath County on the road between Dublin and Victor, where he worked as a laborer for a natural gas company (U.S. Department of Commerce, Bureau of the Census 1920b). They resided at $426 \mathrm{McCauley}$ Avenue in San Antonio by December 1929 . That month, she crossed into the United States at Laredo with 12-year-old Jose Maria Hernandez, her son (FamilySearch 2012a; U.S. Immigration and Naturalization Service, U.S. Department of Justice 1929a). Hernandez was a student and lived with his mother and stepfather (U.S. Immigration and Naturalization Service, U.S. Department of Justice 1929b). By 1930, the Manriquez family had moved to a rental house on Texas Avenue in Texas City with her son. Manriquez worked as a laborer in the Texas Sugar Refining Corporation's factory (Sanborn Map Company 1931:1; U.S. Department of Commerce, Bureau of the Census 1930). Their daughter Lilia was born 
in Galveston on January 1, 1938 (FamilySearch 2102b). Margarita Camarena Manriquez crossed the border again in 1941 at Laredo, this time with her toddler daughter (U.S. Immigration and Naturalization Service, U.S. Department of Justice 1941).

Texas City also became home to other members of the Camarena family in the mid-1940s, when Salvador Camarena's widowed mother, Maria Ramirez, and a sister immigrated permanently to the United States. Ramirez had been staying with a niece, Esther Padilla Ramirez, in Morelia. In August 1944, she arrived in the United States for the first time and traveled to Texas City via Laredo. A daughter, Maria de Jesus Camarena Ramirez, accompanied her but did not stay. Blind in her left eye, the elderly Ramirez may have had other physical difficulties and was unable to support herself. She resided with the Manriquez family at 106 First Avenue South until her April 1946 death (Texas Department of State Health Services, Vital Statistics Unit 1946; U.S. Immigration and Naturalization Service, U.S. Department of Justice 1944). The following year, Maria de Jesus Camarena Ramirez (1909-1999) joined the family in Texas City. She was single at the time and had been a beet field worker in Saspamco, Texas, in 1944 (U.S. Immigration and Naturalization Service, U.S. Department of Justice 1945).

After his father's 1950 death, family members sought a bright future for his young son. Margarita Camarena Manriquez traveled from Texas City to Morelia and took her nephew Jesus Herrera Camarena to Mexico City to acquire a passport. In 1951, he crossed the border into the United States for the first time at Eagle Pass. His cousin, Jose Maria Hernandez, accompanied him to his new home in Texas City (Lilia Manriquez Flores, personal communication, 2012; U.S. Immigration and Naturalization Service, U.S. Department of Justice 1951). He only returned to Morelia once, as a young teenager. He lived with his relatives on First Avenue South in Texas City. He later recognized the educational advantages of residing in the United States, but it was an unhappy experience. As soon as he graduated from high school in 1960, he joined the navy and left Texas City. Jess Camarena did not return to the area until after his father's remains were reburied in La Marque Cemetery in 2013 (Jess Camarena, personal communication 2012, 2014). 


\section{EXCAVATION AND DESCRIPTION OF SALVADOR CAMARENA'S GRAVE}

The initial investigation of the gravesite was conducted by Texas Department of Transportation (TxDOT) archeologist Christopher Ringstaff on January 17, 2011, 61 years to the day after the body of Salvador Camarena was found and reported to Maverick County officials (see Chapter 2 and Appendix A). This sole purpose of the investigation was to confirm whether or not the iron-pipe fence and cross marked a human grave (Ringstaff 2011). The work consisted of moving the $9 \times 12$-ft iron enclosure and cross and then scraping the area with a Gradall to look for evidence of an intrusive grave (see Figures 2.3 and 2.4). The mechanical stripping removed a few inches of sediment at a time until reaching approximately $30 \mathrm{~cm}$ below surface, where a shoe sole and some human bones were observed. An arm bone (radius) was found about $110 \mathrm{~cm}$ from the shoe and foot elements (metatarsals), indicating that a fully extended and articulated skeleton was oriented in the same direction as, and had been centered within, the rectangular pipe enclosure. Although no casket wood or mottled grave shaft fill was observed, the work confirmed that the location was an intact human grave. The grave was protected with a section of the pipe enclosure and hand-shoveled fill, and the rest of the excavation was backfilled with the removed sediment.

At the time of this initial investigation, the intent was to return to exhume the burial remains, but there was conflicting information about whom and how many people might be buried in this roadside grave. One informant believed it was the grave of a ranchhand who died in the $1970 \mathrm{~s}$, and another believed it was a memorial marker for a relative killed in an automobile accident in 1983 and buried else- where. Both of these reports proved incorrect, and Ringstaff's subsequent research provided evidence that identified the location as the gravesite of Salvador Camarena, from Morelia, Mexico.

Following the 2011 preliminary investigation, TxDOT began planning for the next stage of work, which included attempts to locate next of kin, excavation and removal of the grave from the highway right of way, and eventual reinterment of the burial remains. TxDOT contracted with Prewitt and Associates, Inc. (PAI), to assist in these efforts.

\section{BURIAL EXCAVATION}

Archeologists returned to the gravesite along FM 481 to exhume the burial on October 10 and 11, 2012. Ringstaff and Dr. Catrina Banks Whitley ${ }^{6}$ conducted the work, using hand excavations to carefully expose the remains. ${ }^{7}$ Shovels were used initially to skim off overburden in some areas, but trowels and wooden digging tools were then used when digging close to the human remains (Figure 4.1). The excavations began at the foot end of the grave, exposing the shoe and left foot. The right shoe and most of the bones of the right foot were missing. There are three plausible explanations for this: (1) the shoe and foot elements were missing when the body was first discovered; (2) these elements were dislodged and lost in the process of moving the body to the gravesite; or (3) they were unin-

\footnotetext{
${ }_{6}$ Whitley is a consultant for PAI and operates under the business name of Bioarchaeology Support in Midlothian, Texas.

7 Mike Graham, Environmental Coordinator for TxDOT's Laredo District, assisted in the removal of the skeletal remains.
} 
tentionally removed during the initial Gradall scraping in 2011.

The excavation continued, following the articulated remains from the feet to the legs, to the pelvic region, the lumbar vertebrae and chest area, and finally the upper part of the grave, where the arms and cranium were exposed. Many of the bones of the left hand and some of the right hand bones were missing. Like the bones of the right foot, these small hand elements could have already been missing when the body was found or been inadvertently removed during the initial burial or the mechanical scraping.

Photographs documented the work as it progressed, and the complete exposed grave was photographed and sketched in detail (Figure 4.2). Some glass fragments were in the fill above the burial, but they were determined to be modern roadside trash. All other artifacts recovered were found near the skeletal remains and were personal items and mortuary objects interred with the deceased.

\section{BURIAL DESCRIPTION}

\section{Mortuary Characteristics and Burial Taphonomy}

The skeletal remains and associated items were encountered at between 26 and $39 \mathrm{~cm}$ below the current ground surface. No evidence of an intrusive grave shaft or a burial container was observed. This lack of evidence is attributed to the fact that the entire grave was in the upper A horizon, where sediments were extensively bioturbated. It is likely that the grave was originally somewhat deeper than at the time of excavation and that erosion washed away some additional covering sediment. An arc-shaped iron rust stain was observed about $20 \mathrm{~cm}$ beyond the southern end of the skeleton, where the large iron cross had marked the grave.

Bioarcheologist Whitley identified the skeletal remains as those of an adult male. The man was interred lying face down, and the body was laid out fully extended, with the head to the south and the feet to the north (the body was oriented at approximately 29 degrees off of magnetic north). The skull was detached from the cervical vertebrae; this most likely occurred at the time of the burial because the body was recovered in an advanced stage of decomposi- tion. The skull was offset to the west but was positioned upright (with the foramen magnum downward) and was facing northwest.

The skeletal remains were relatively intact, which is remarkable since the grave was so shallow and occurred inside a highway right of way. This suggests that the iron grave fence and marker were installed not long after the highway was widened and encompassed the grave, thus protecting the shallow grave from compaction and damages caused by highway maintenance vehicles (e.g., tractors used to mow inside the right of way). Although the bones were intact, they are not particularly well preserved. This is presumably because the shallowness of the burial meant that they were susceptible to repeated wetting and drying as well as extensive chemical weathering by root etching. Spongy bone and small bones were particularly friable. The ribs and vertebrae were fragile, and they fragmented under slight pressure.

\section{Summary of the Osteological Interpretations}

Dr. Katherine Spradley conducted the analysis of the skeletal remains. The results are reported in detail in Chapter 5 and Appendix B and are briefly summarized here.

Spradley identified the remains as a male approximately 40 to 50 years old at death, and between $5 \mathrm{ft} 1 / 2$ inch and $5 \mathrm{ft} 51 / 4$ inches tall. The bones exhibited minimal age-related degenerative changes in the shoulders, arms, and legs, and evidence of a nonspecific periosteal infection was present on his right arm. An unusual amount of osteoarthritic activity was observed on the cervical vertebrae, but not on the thoracic or lumbar vertebrae; this may indicate that the individual had suffered some type of traumatic injury. No evidence of perimortem trauma was found, and the skeletal remains do not suggest or reveal anything about the cause or manner of death.

After compiling the data for this individual, Spradley compared it with osteological data for selected twentieth-century black, white, and Hispanic populations. Comparisons indicate that the remains are of a Hispanic male, and they are most similar to the remains of other Mexican migrant workers who died at border crossings. Thus, the osteological evidence from the skeletal 
Chapter 4: Excavation and Description of Salvador Camarena's Grave
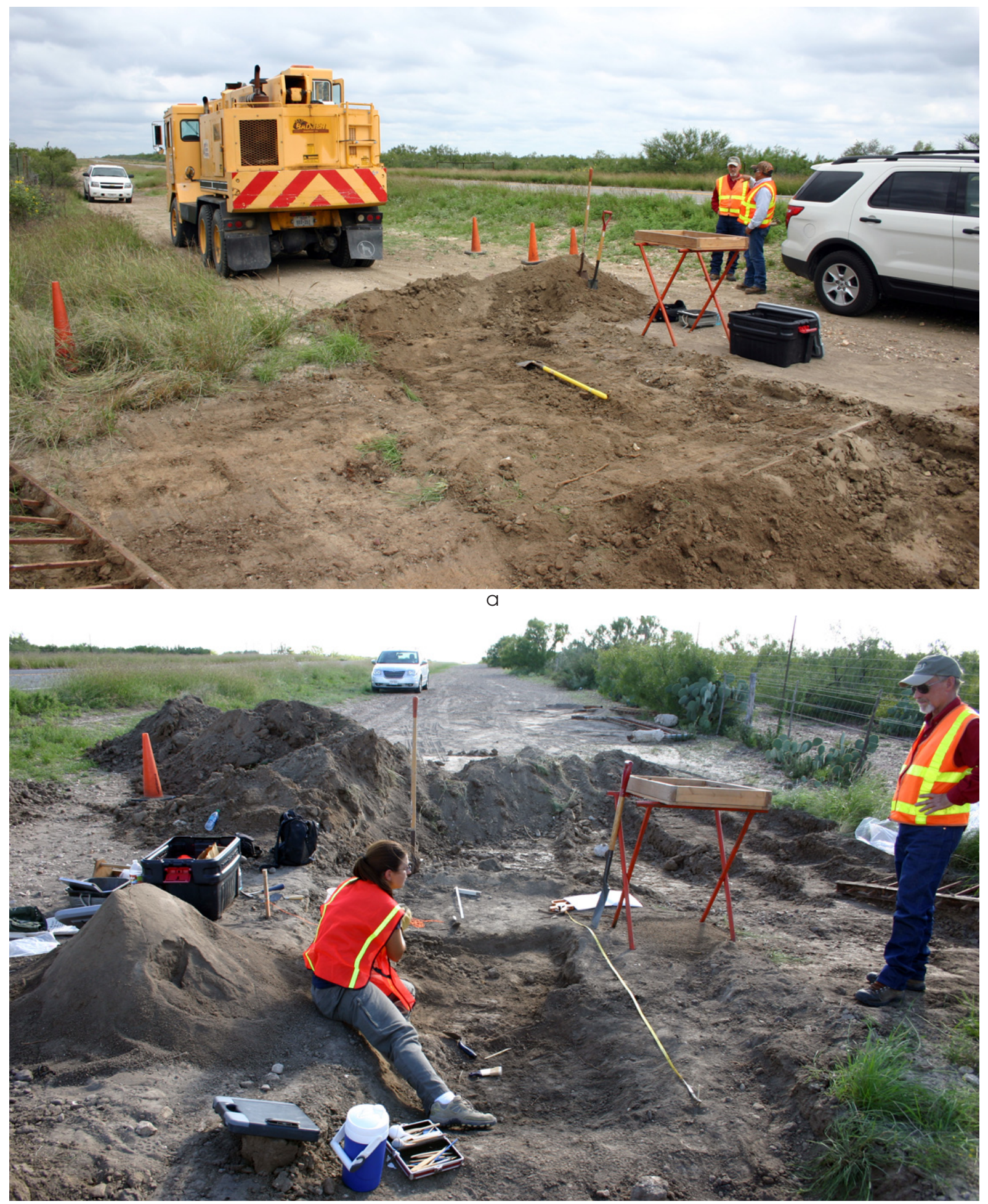

b

Figure 4.1. Photographs of the Camarena gravesite excavations in progress. (a) View northeast of the gravesite in the FM 481 right of way. The shovel marks the location of the grave. (b) View south of the hand excavations of the upper portion of the grave. Bioarcheologist Catrina Banks Whitley is sitting on the east side of the grave. 
D E P T H (below ground surface)

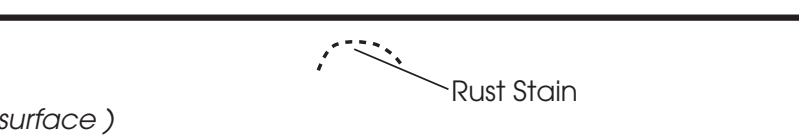
(1) $26.5 \mathrm{~cm}$
(2) $36 \mathrm{~cm}$
(3) $37.5 \mathrm{~cm}$
(4) $30 \mathrm{~cm}$
(5) $29 \mathrm{~cm}$
(6) $33 \mathrm{~cm}$
(7) $26 \mathrm{~cm}$
(8) $26.5 \mathrm{~cm}$
(9) $38.5 \mathrm{~cm}$

LE EN D
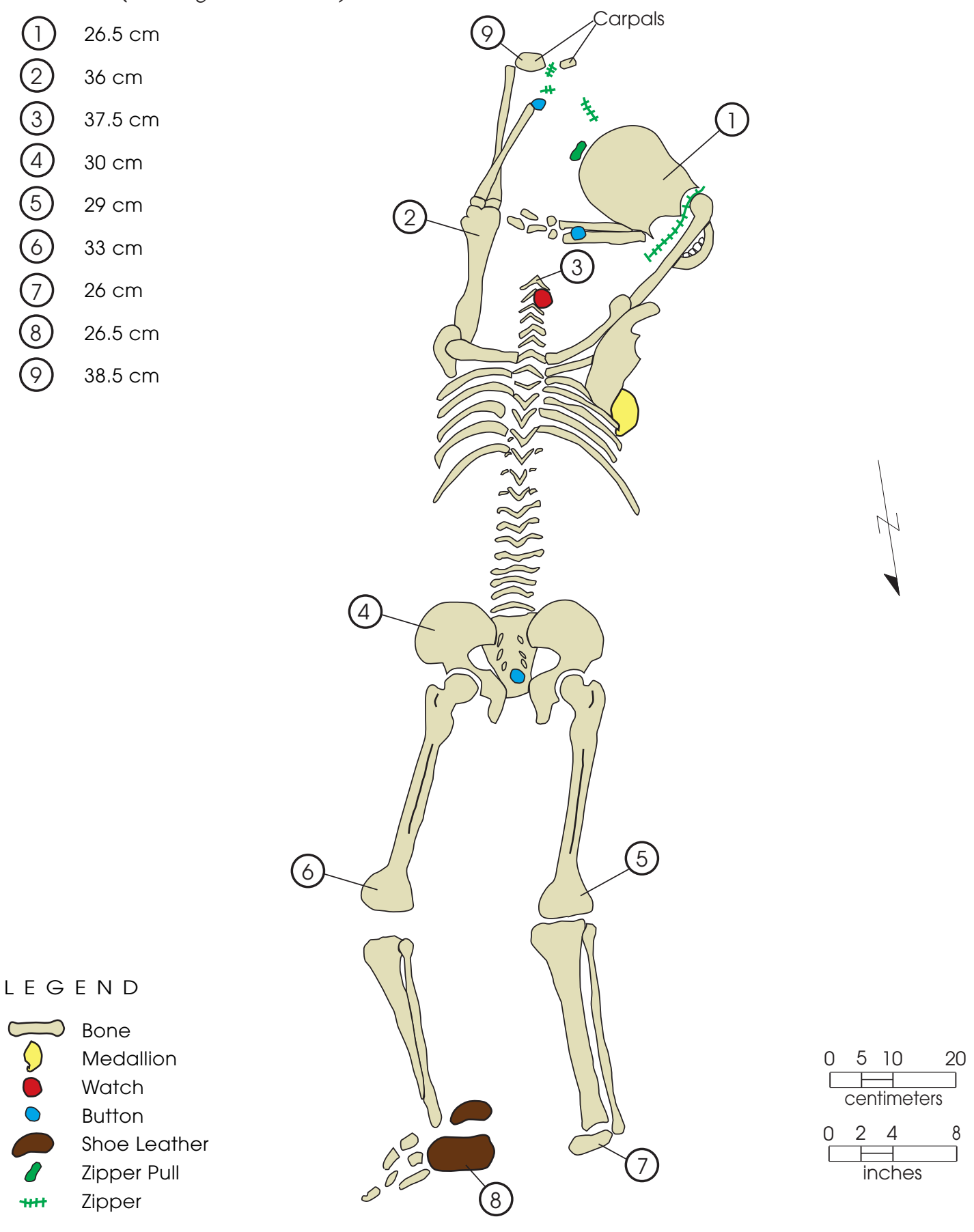

PAI//4/BW

Figure 4.2. Plan map of the Camarena grave with remains exposed between 26 and $39 \mathrm{~cm}$ below the surface. Map is based on original field map by Catrina Banks Whitley. 
remains corresponds with the historical evidence that identifies this individual as Salvador Camarena, who was originally from Morelia, in the state of Michoacán, Mexico. Pupae casings found in the cranial vault provide further evidence that the body was exposed to the elements before burial, an observation noted on his death certificate (see Figure 3.1).

\section{Description of Personal and Mortuary Items}

Personal items recovered with the body indicate that Camarena was wearing a shirt and light jacket, trousers, shoes, and a wristwatch at the time of his death (see Figure 4.2). He was also buried with a religious medallion, which was probably suspended on a necklace made of perishable material. The medallion is presumed to have been a personal item that he wore rather than a mortuary item placed with him at the time of burial. As described earlier, the body was not in a casket, and the only definite mortuary artifact found in the grave were fabric remnants from artificial flowers. These burial-associated items are described below.

\section{Buttons}

Three two-hole buttons were found, made of a hard synthetic material, probably plastic or rubber (Figure 4.3). All three are small, 1.0 to $1.2 \mathrm{~cm}$ in diameter. Two were at the wrists and are probably cuff buttons from a shirt or jacket.

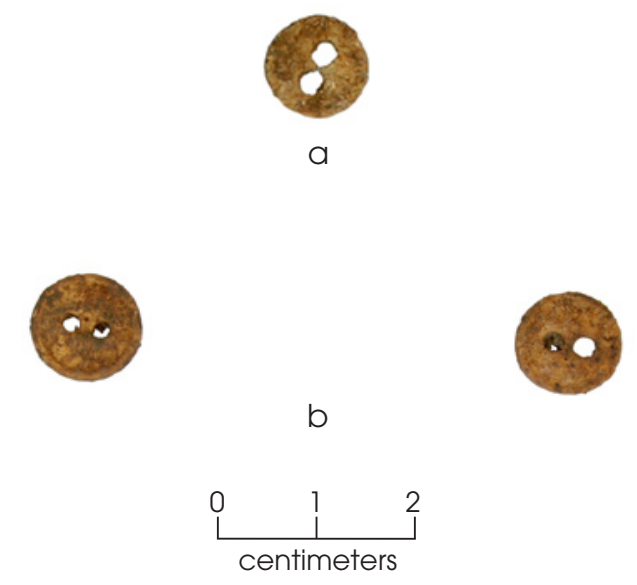

Figure 4.3. Two-hole buttons.
The third button was found near the sacrum and is probably from a pair of trousers.

\section{Zipper Fragments and Zipper Pull}

Multiple zipper fragments and a zipper pull were recovered, and these were all found in the upper portion of the grave, around the head and arms. The zipper fragments and pull are some type of metal alloy with enough copper content that they are stained green (Figure 4.4). One zipper section was approximately $8 \mathrm{~cm}$ long with the zipper pull attached and fabric adhering to one side (see Figure 4.4a). Another nearly $15 \mathrm{~cm}$ long was next to the right forearm, which was lying over the skull. This zipper section undoubtedly caused the green staining on the lower right eye orbit and other parts of the skull observed in the field and during the osteological analysis (see Chapter 5). The zipper sections were very fragile and broke into sections when they were removed. Some small sections of fabric adhered to the zipper fragments and zipper pull. It is likely that the cuprous salts from the metal zipper fragments aided in the preservation of this fabric.

The zipper sections are interpreted as part of a light jacket or coat. Collectively, the pieces account for only a small portion of a full-length zipper. It is likely that the jacket was damaged and some zipper sections were detached and lost during the period of exposure prior to burial. Based on the placement of the zipper fragments in the burial, it is surmised that the jacket was pulled up over the man's head at the time of interment.

\section{Shoe Sole and Heel}

Five pieces of a shoe were in place near the left foot (Figure 4.5). Two pieces refit to form a complete hard rubber shoe sole that is approximately $25 \mathrm{~cm}$ long. This sole is machine-made with some iron staining in the heel area where a piece of metal had been. The third specimen is a small iron fragment near the left foot, which probably came from a shoe. The last two pieces are part of a black, hard rubber shoe heel with a series of iron-stained nail holes around the perimeter. Based on the length of the sole, it is estimated that the shoe was a men's size 7 to 8 . 


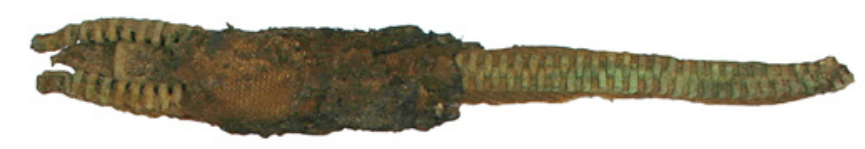

a
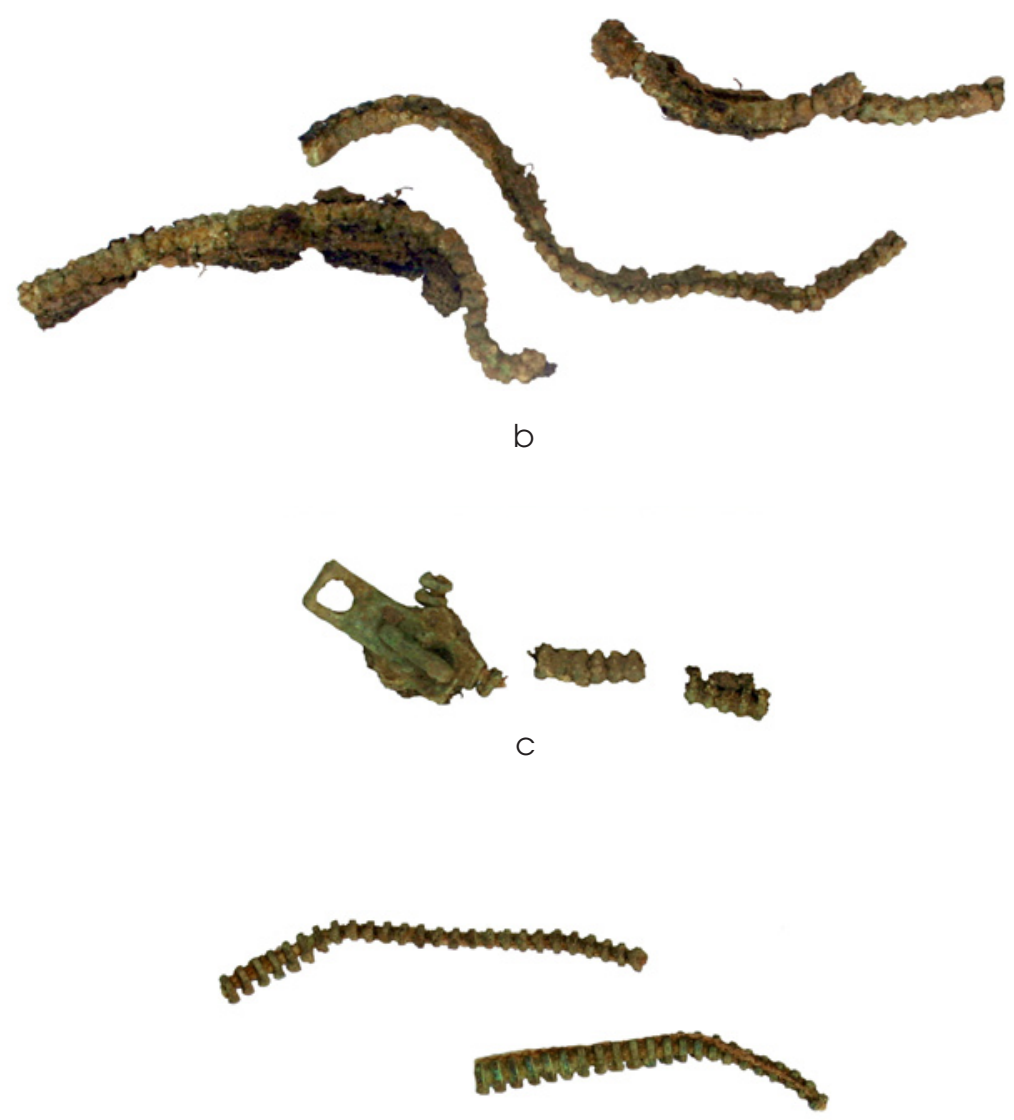

d
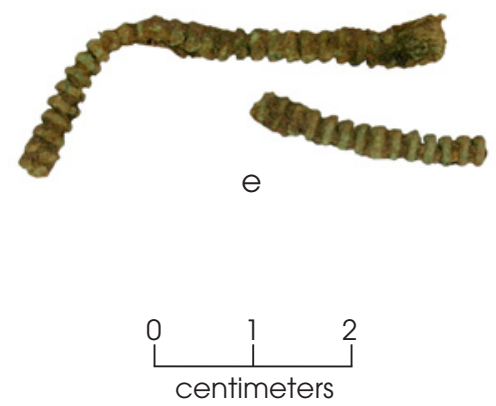

Figure 4.4. Zipper pull and zipper fragments. (a) Intact section of zipper with interlocked zipper pieces and fabric remnant; (b) zipper section with interlocked pieces pulled apart; (c) zipper pull and zipper pieces with fabric remnant; (d-e) separate zipper sections. 


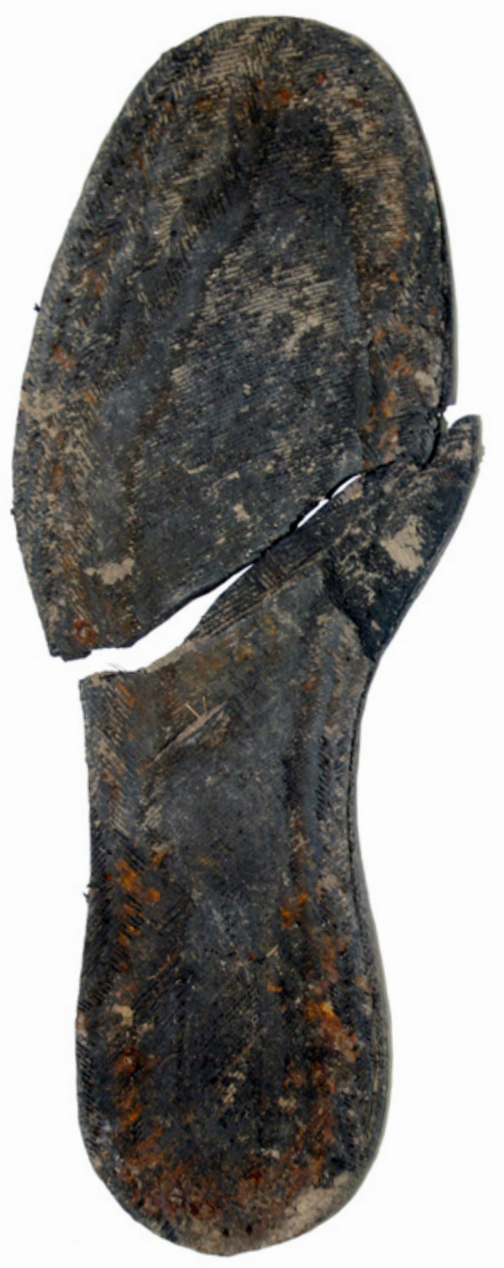

a

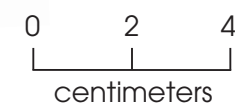

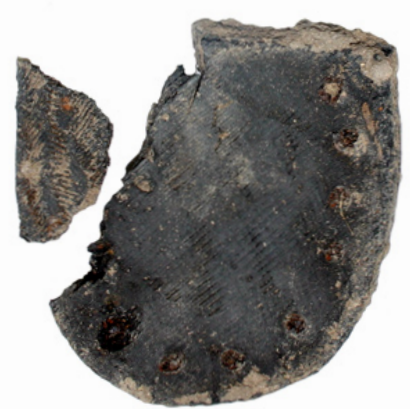

b

Figure 4.5. Fragments of a left shoe. (a) Shoe sole; (b) shoe heel.

\section{Wristwatch}

A metal wristwatch and fragments of a leather wristband were together lying under cervical vertebrae in the general vicinity of the head and arms (Figure 4.6). Although some type of postdepositional disturbance could have moved this object within the grave, it is speculated that the wristwatch was already loose and was not on the individual's wrist at the time of burial. The crystal was not found.

The metal watch was analyzed and described by TxDOT archeologist Waldo Troell. He provided these observations:

The condition of the watch is poor due to having been buried for an extended time in the soil allowing the soil chemicals and moisture to badly corrode and oxidize the wristwatch surface. The internal watch movement was observable because most of the back cover had corroded to the point that only the rim of the back cover is still attached to the watch housing body. The metal body of the watch is pitted and blistered. The watch movement is in better condition because many of its internal components are brass and it was protected to some degree by the watch housing. 

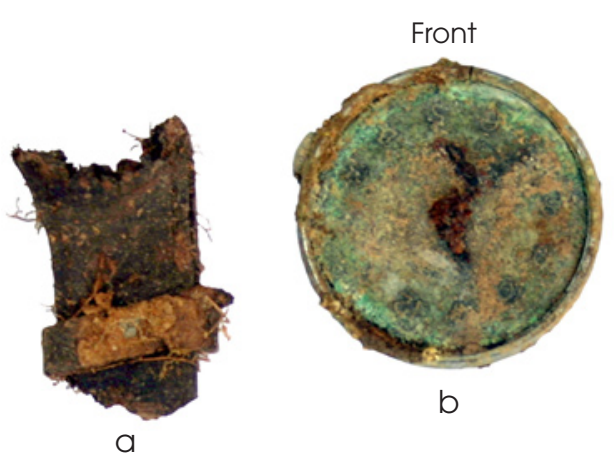

b

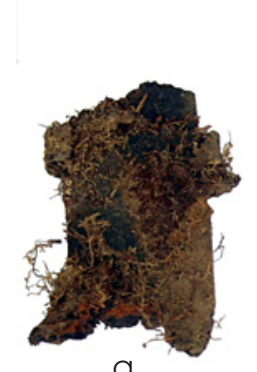

a
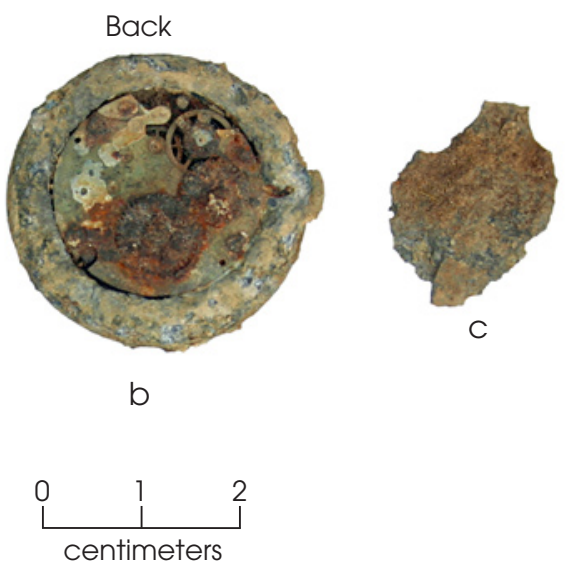

Figure 4.6. Metal wristwatch and wristband remnant, views of front and back sides. (a) Leather wristband remnant; (b) wristwatch; (c) fragment of watchcase back.

The wristwatch includes remnants of a brown leather wristband that would have attached to the metal watch body that is composed of an unknown white metal alloy that was originally silver in color. The width of the watchcase is $32 \mathrm{~mm}$. The winding knob is at the three o'clock position with no pendent bow or swing ring suggesting that it was a pocket watch. The large round painted metal dial is $30 \mathrm{~mm}$ in diameter and it has a sub dial for the second hand. Both dial faces have easy-to-read raised Arabic numbers and tick marks with arrow hands that are all typical of a military-style watch. The main dial face appears to have a brand name or model name on it but due to corrosion only the letters "EN" can be deciphered. The wrist watch was incomplete due to corrosion, and several elements were missing, including the crystal cover over the dial (glass or plastic), most of the leather wristband, the wristband buckle, the watch lugs (most likely soldered lugs on two opposing sides), and the two pins that would have fastened the wristband to the watch.

The watch had stopped at the approximate time of 10 hours, 39 minutes, and 12 seconds. A mechanical pin lever watch will stop running when the watch main spring winds down, when the movement train becomes damaged due to an impact, or when the movement wears out. Since the watch was still in use when the individual died, an examination was performed to determine what might have caused it to stop running. Because the watch was badly corroded, the main spring could not be viewed, without badly damaging the watch housing, to see if it had wound down. ${ }^{8}$ In contrast, another critical part of the watch mechanism could be viewed. The weakest point in the movement train is the balance wheel and hairspring, and this is the most likely place for a break to occur due to an impact. An examination of the balance wheel and the attached hairspring suggests that the watch was still intact. Consequently, it appears that the most likely cause of the watch stopping is from the normal winding down of the mainspring.

This specimen has a manual wind, mass-produced, pin lever, non-jeweled movement that resembles a generic style produced in Switzerland. Swiss manufacturers sold these types of movements to many different watch companies around the world to be placed inside their own watches. During the late nineteenth century and first half of the twentieth century, the Swiss were the number

\footnotetext{
8 Because the wristwatch was a personal belonging owned by the deceased and would be reinterred with the remains, we did not want to damage the watch in any way.
} 
one manufacturers of inexpensive to moderate-priced watches before becoming known for their expensive jeweled watches. Pin lever, nonjeweled watches were sometimes known as "dollar watches" because they could be purchased for a few dollars and were typically thrown away when the watch wore out or broke. The typical life span was two or three years of service. The dollar watches were known for being rugged and practical watches that could be used at work but still look decorative and attractive in social settings.

The style of this wristwatch matches a popular 1940s-era civilian watch that was patterned after military watches popularized during World War II (1939-1945). This style of watch was quickly replaced in the early 1950 s with more modern sleek, polished, and minimized looks influenced by the jet and space age. In comparing this specimen to ones illustrated in the Complete Price Guide to Watches (Shugart et al. 2003), this wristwatch most closely matches the ones manufactured ca. 1945. With a dial width of approximately $30 \mathrm{~mm}$, the size of the watch is approximately a Swiss 13 Lignes or an American 0 size, which is typical for a man's wristwatch.

\section{Religious Medallion}

A religious medallion was lying face down underneath the right side of the ribcage. The round medallion is made of some type of rigid plastic or other synthetic material, and it measures approximately $5.6 \mathrm{~cm}$ in diameter and is only a few millimeters thick (Figure 4.7). Given its location in the grave, it is likely that Camarena had it inside a pocket of his shirt or jacket or perhaps wore it as a necklace. This specimen has no visible means of suspension, but it could have been set into a frame of cloth, wood, or some other perishable material. The face of the medallion has a multicolored painted image of the Nuestra Señora de Guadalupe (Our
Lady of Guadalupe), a popular religious symbol for Catholic Mexicans (Brading 2001).

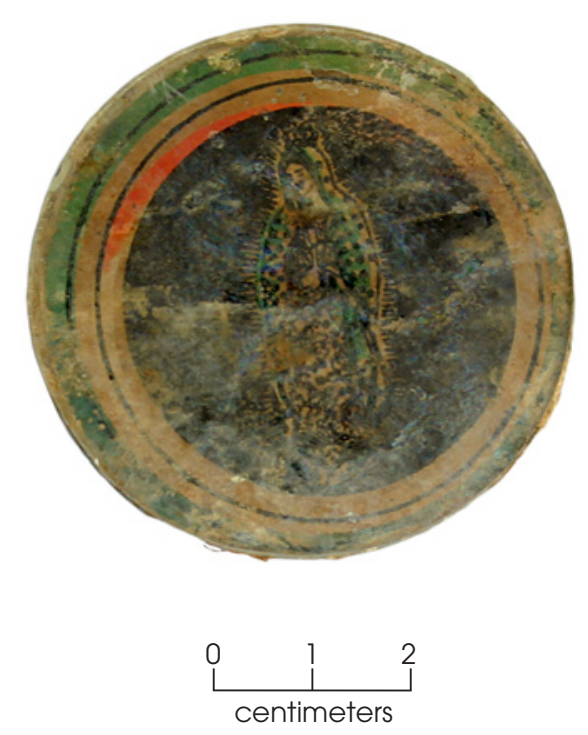

Figure 4.7. Religious medallion.

\section{Fabric Remnants}

Numerous fragments of fabric were in the lower part of the grave, around the lower legs of the deceased. The fabric remnants include many pieces that are multicolored green, red, and brown artificial leaves and other single-colored pieces without any apparent form (Figure 4.8). It is likely that all of the fabric remnants are part of a simple arrangement of artificial flowers that was placed into the grave at the time of the burial.

\section{CORRELATING THE EVIDENCE}

The archeological evidence from the burial excavation corresponds in many details with information derived from the osteological analysis of the remains (see Chapter 5) and historical evidence derived from the archival research and family interviews (see Chapter 3 ). The collective data reveals much about the death and burial of Salvador Camarena.

According to Camarena's death certificate, he died some 10 to 15 days before his body was found, which confirms why the Maverick County officials opted for a quick burial of the re- 


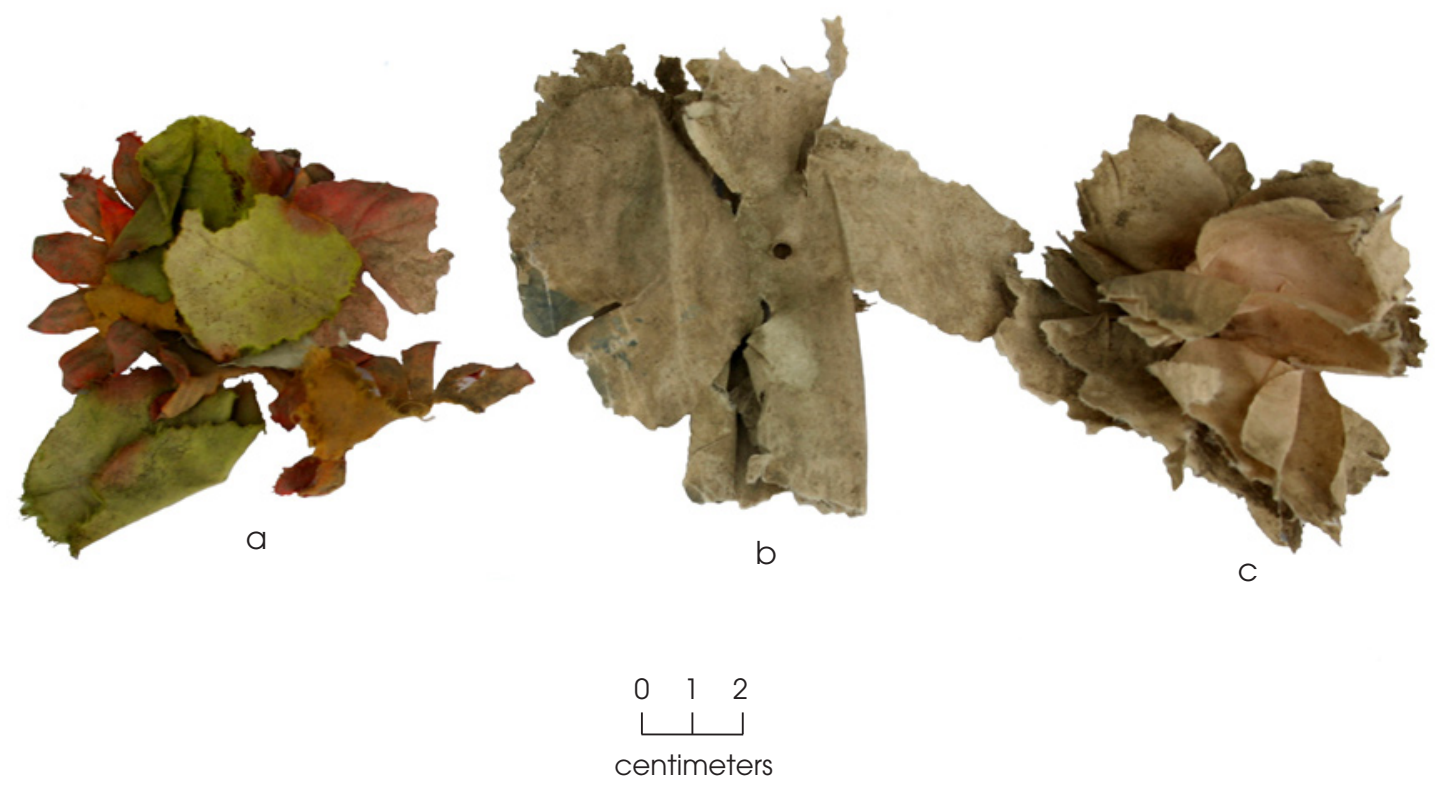

Figure 4.8. Fabric remnants from an artificial floral arrangement. (a) Multicolored (green, red, brown) fabric in the form of artificial leaves; (b) grayish-brown fabric; (c) brown fabric.

mains. It is likely that the body was mostly intact when it was discovered, but it had to be moved some distance (an unknown distance but presumably not very far) from where it was found to the grave alongside the road. It is surmised that the people who buried Camarena's body dragged the remains to the gravesite by holding the arms of the jacket. By doing this, they extended his arms above his head and dislodged his wrist- watch, causing it to fall off. Most of the watch remained inside the jacket, but the crystal cover was knocked off and lost. The skull may have been disarticulated while the body was being moved and placed into the grave. The position of the remains, with the body lying face down and the skull detached, is consistent with a hasty burial of a body that was moved some distance and was perhaps rolled into the grave. 


\title{
ANALYSIS OF HUMAN REMAINS
}

5

\author{
M. Katherine Spradley
}

On October 12, 2012, human remains excavated from the marked grave of Salvador Camarena were delivered to the Department of Anthropology at Texas State University for skeletal analysis. ${ }^{9}$ The results of the analysis are summarized in Table 5.1. The human remains were documented and analyzed following protocol outlined in Standards for Data Collection from Human Skeletal Remains (Buikstra and Ubelaker 1994). The remains were clean prior to arrival with the exceptions of a light layer of soil that adhered to the overall skeleton and soil left inside the cranial vault for transport. After the skull was removed from the transport box and photographed, the soil was removed. The removal of the soil caused the craniofacial complex to separate from the cranial vault. Despite the separation, some craniometric data was collected along with the postcranial data. The remainder of the skeleton was brushed free of dirt for examination.

The skeleton was mostly complete (Figure 5.1), with the exception of some hand and foot bones (see Appendix B). The skeleton was stained a light to medium brown from the burial, and roots were on most of the bones, with the heaviest concentration on the cranium and mandible. Pupae casings were in the cranial vault after soil removal, suggesting that the burial was not immediate. Green staining was present on the lower right eye orbit, the ante-

\footnotetext{
9 Dr. Spradley is with the Department of Anthropology and Forensic Anthropology Center at Texas State University. She conducted the analysis with assistance from students Justin Pyle, Gabrielle Lavallo, Reina Garcia, Cristina Watson, and Kathryn Taylor. This chapter is an updated version of the original osteology report completed in December 2012.
}

Table 5.1. Skeletal analysis summary

\begin{tabular}{l|l}
\hline \multicolumn{1}{c|}{ Sex } & \multicolumn{1}{c}{ Male } \\
\hline Age & 40 to 50 years of age at death \\
\hline $\begin{array}{l}\text { Biological } \\
\text { Affiliation }\end{array}$ & Hispanic \\
\hline Stature & $5 \mathrm{ft} 1 / 2$ in to $5 \mathrm{ft} 51 / 4$ in \\
\hline Pathology & $\begin{array}{l}\text { Age-related degenerative changes } \\
\text { and nonspecific periosteal infection }\end{array}$ \\
\hline
\end{tabular}

rior surface of the maxilla at zygo-orbitale, and on the right superior-posterior parietal bone. No repeated bone elements were in the box containing the human remains. Additionally, no skeletal elements indicated differing age ranges. Thus, the skeletal remains represent one individual.

\section{SEX: MALE}

The pelvis provides the best indicator of sex, followed by the long bones and the skull, respectively. Gross morphological features such as the ventral arc, ischiopubic ramus ridge, greater sciatic notch, and the preauricular sulcus (as outlined in Buikstra and Ubelaker 1994) all score ambiguous rather than male. However, based on the narrow iliac blades and the marked muscle attachment sites on pelvis and long bones, the skeleton is consistent with male. Postcranial metrics were also used to estimate sex. Using sectioning points derived from modern skeletal reference data predominantly from Mexico (Tise et al. 2012), the skeleton is male (Table 5.2). 


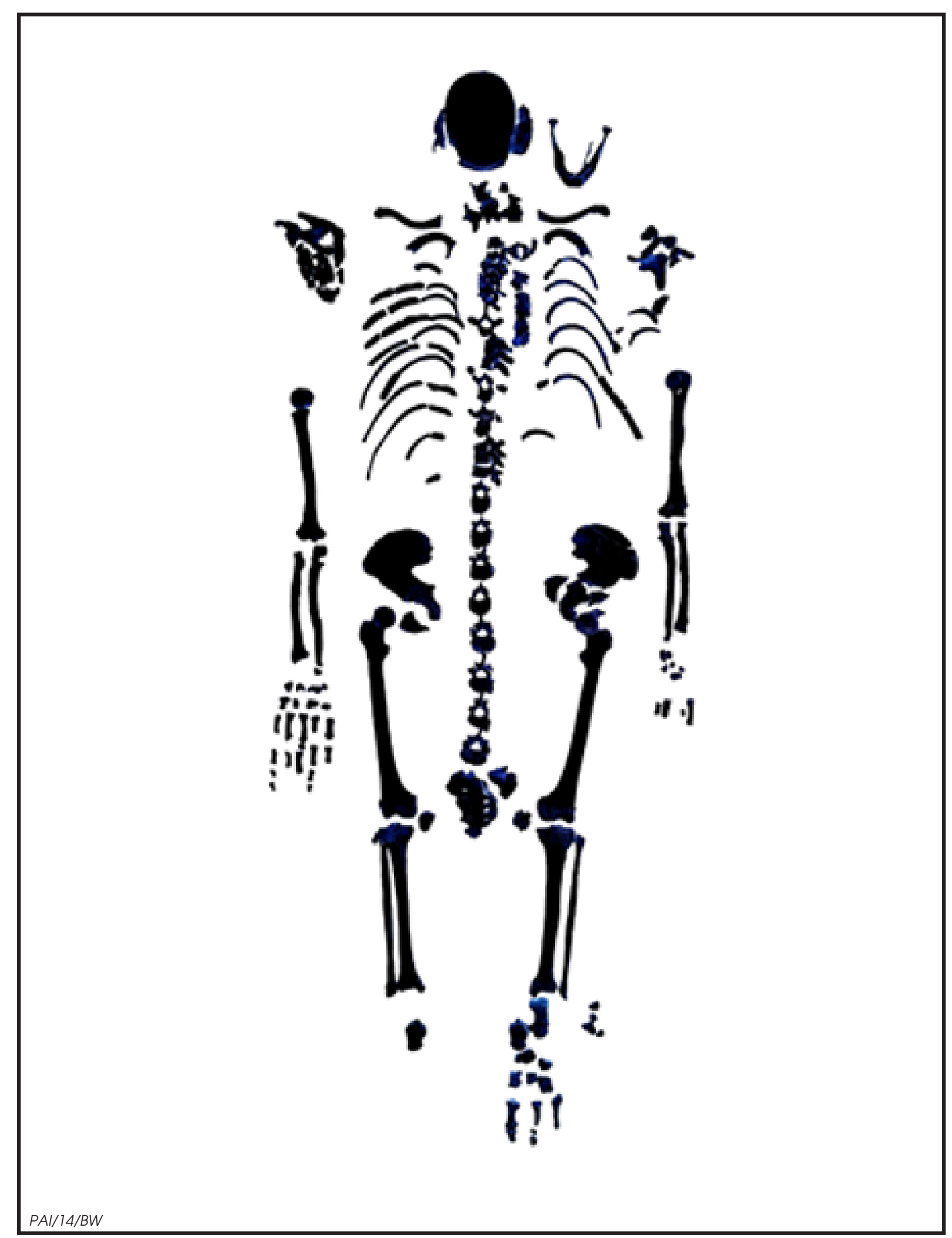

Figure 5.1. Schematic inventory of skeletal remains from the Camarena burial. 
Chapter 5: Analysis of Human Remains

Table 5.2. Sectioning points for sex estimation derived from modern Hispanic reference data (Tise et al. 2012)

\begin{tabular}{l|c|c|l|c}
\hline \multicolumn{1}{c|}{ Measurement } & $\begin{array}{c}\text { Sectioning } \\
\text { Point }(\mathrm{mm})\end{array}$ & $\begin{array}{c}\text { Camarena } \\
\text { Data }(\mathrm{mm})\end{array}$ & Classification & $\begin{array}{c}\text { Classification } \\
\text { Accuracy }\end{array}$ \\
\hline Humeral head diameter & 43 & 45 & Male & $86 \%$ \\
\hline Femur head diameter & 43 & 47 & Male & $84 \%$ \\
\hline Tibia circumference at nutrient foramen & 88 & 95 & Male & $81 \%$ \\
\hline
\end{tabular}

Tise et al. (2012) report multiple sectioning points for sex estimation. The sectioning points used for this analysis were based on whether or not the metric data was available due to postmortem damage. The sectioning points provide a simple means of sex estimation from single measurements. If a specific measurement falls above the sectioning point, it is classified as male, and if it falls below, it is classified as female. The classification accuracy for each sectioning point is indicated in Table 5.1.

Features of the skull-such as the nuchal crest, mastoid processes, glabella, and mental eminence-also provide scores indicating that the deceased was male.

\section{AGE: 40-50 YEARS}

Skeletal age at death was assessed using a multifactorial approach, with primary emphasis on the pubic symphysis and auricular surface for an adult individual. There are no unfused or fusing epiphyses visible on this individual, and dental eruption is complete. Therefore, the pubic symphyses and auricular surfaces, along with overall degenerative changes, were used to estimate age.

The pubic symphyses were scored following the descriptions outlined in Suchey and Katz (1998). The pubic symphyses, both left and right, exhibit poor preservation with destruction at the superior face (Figure 5.2). The right pubic symphysis displays a complete rim, with a worn face, and irregularity. The right side also exhibits a faint display of ridges, irregularity, and minimal lipping. The left pubic symphysis exhibits a rim on the portion present, irregularity, and minimal lipping. The right pubic symphysis score is IV/V with a mean age at death of 35.2/45.6 and range of 23-57/27-66 years of age at death. The score for the left side is Phase $\mathrm{V}$ with a mean age of 45.6 and range of 27-66 years of age at death.
The auricular surface scores follow the methods in Lovejoy et al. (1985) found in Buikstra and Ubelaker (1994). The right auricular surface displays transverse organization around the apex and inferior and superior demiface. The superior demiface on the right side also shows early signs of densification. Overall, the right surface is granular, with microporosity and some islands of irregularity. The left auricular surface displays no transverse organization; the surface is granular with micro- and macro-porosity and no apical activity. Overall, the left surface is irregular and rugose, and densification is present at the apex (Figure 5.3). The right auricular surface score is a phase $4 / 5$ with an age range of $35-44$ years of age at death. The left auricular surface score is a phase $6 / 7$ with an age range of $45-59$ years of age at death.

The joint surfaces, including the glenoid fossa of the scapula, the humeral epicondyle, and the femur and tibia articular surfaces, display minimal signs of degenerative joint disease. Based on the age ranges from the pubic symphysis and auricular surface, taken together with the overall condition of the skeleton, the estimated age at death is 40 to 50 years.

\section{BIOLOGICAL AFFILIATION: MOST SIMILAR TO MODERN MEXICANS}

The cranial and postcranial skeleton provides reliable estimates of ancestry, due to the heritability of skeletal traits, using multivariate statistical approaches. Based on the incomplete nature of this cranium, there are not enough craniometric variables to use for ancestry analysis. However, postcranial ancestry estimation was employed using reference data from three groups: twentieth-century Hispanics, represented by migrants who died attempting 


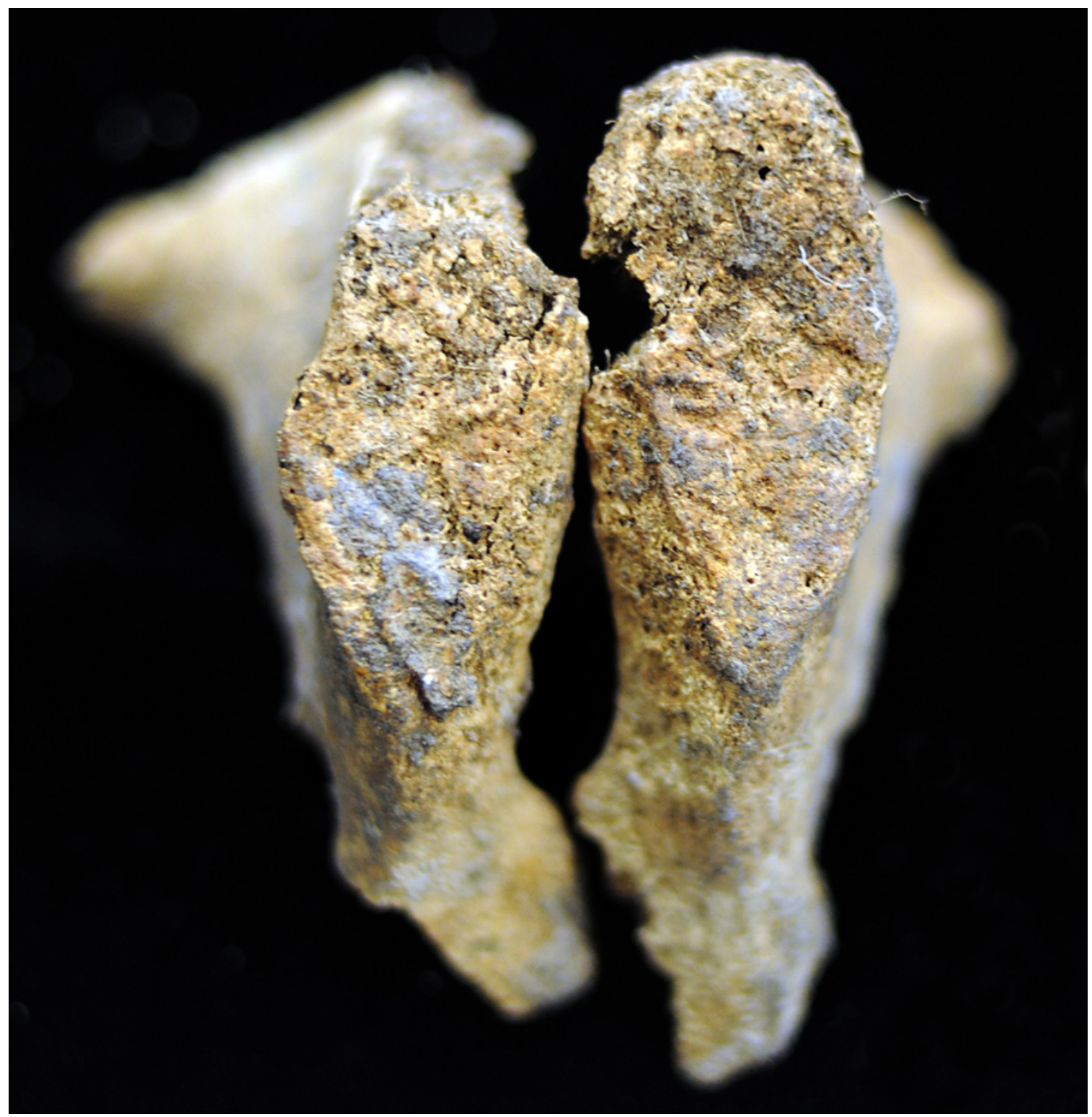

Figure 5.2. Closeup views of the left and right pubic symphyses.

to cross the U.S.-Mexico border ( $\mathrm{n}=29$, data collected by the author), and twentieth-century American blacks $(\mathrm{n}=39)$ and whites $(\mathrm{n}=155)$, from the Forensic Anthropology Data Bank (Jantz and Moore-Jansen 1988). The majority of the migrant sample is contextually identified as Mexican based on a cultural profile outlined in Anderson (2008), although some are positively identified as Mexican through DNA or dental radiographs. For the purposes of the current analysis, the migrant sample will be referred to as "Hispanic."
Because individuals from Mexico have a complex population structure from several parental groups (Native American, European, and African), estimating biological affiliation is difficult. Jantz (2010) found that long bone lengths perform well in postcranial ancestry analysis when analyzing blacks, whites, and Hispanics. Thus, for the purpose of this analysis, long bone lengths from clavicle, humerus, radius, unla (physiological length), femur (maximum and bicondylar), and tibia lengths were used to provide an estimate of ancestry. Because the 


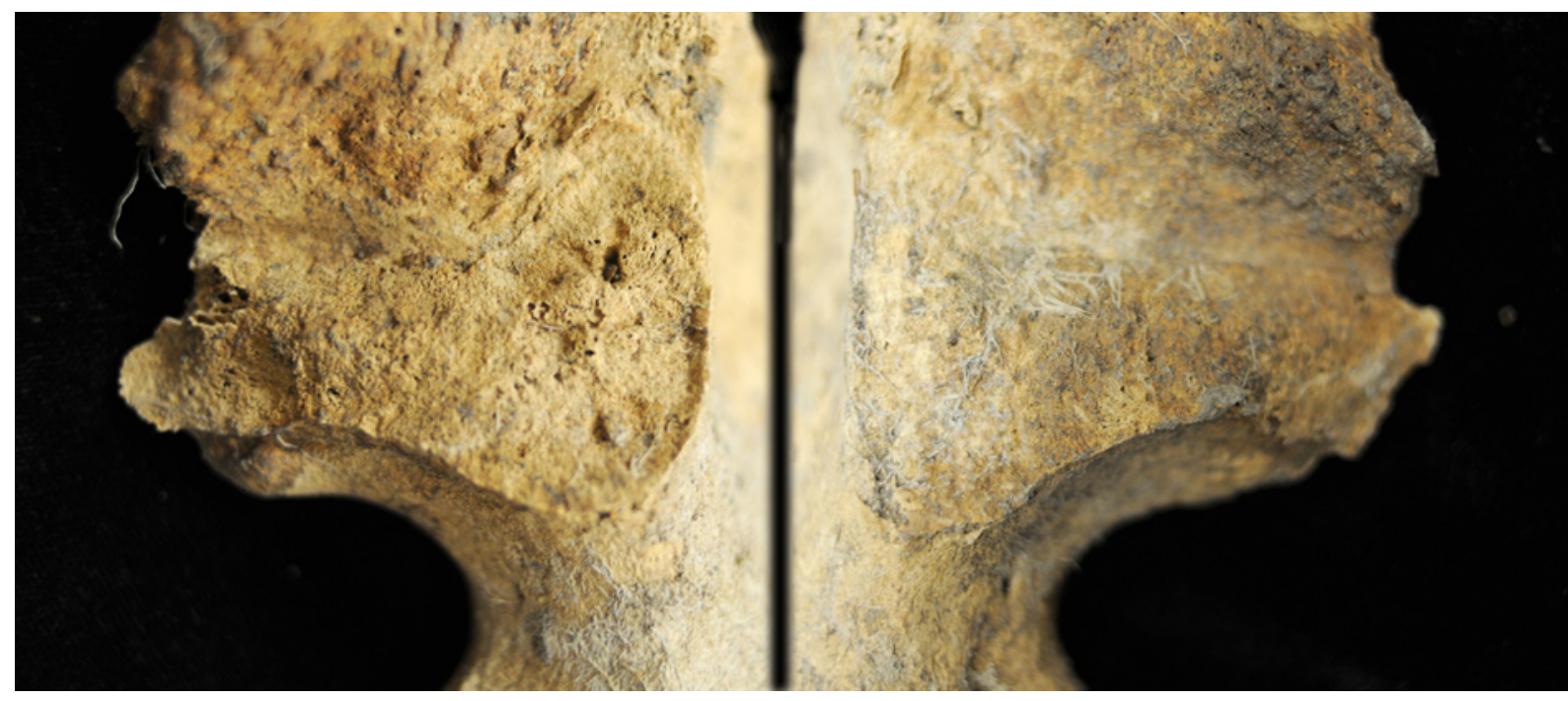

Figure 5.3. Closeup views of the left and right auricular surfaces.

Camarena skeleton is male, only males were used in the analysis.

First a discriminant function analysis was run to generate a Mahalanobis squared distance $\left(\mathrm{D}^{2}\right)$ matrix using SAS 9.1.2. The matrix $\mathrm{D}^{2}$ is a measure of biological similarity between groups. Camarena was input as a single reference group in order to obtain a $\mathrm{D}^{2}$ value. Next, the $\mathrm{D}^{2}$ matrix was double centered to remove effects of small sample sizes, and the resulting eigenvectors were extracted and plotted in two dimensions to view the biological distances between all reference groups and Camarena. The resulting plot (Figure 5.4) shows only 9.5 percent of the total variation. The first axis separates Camarena from all other groups, and the second axis sepa- rates the American blacks from all other groups, with Camarena intermediate.

The interpretation of the $\mathrm{D}^{2}$ distances and two-dimensional plot suggests that Camarena is most biologically similar to the Hispanic group and least similar to the American black group. The isolated position of Camarena is likely due to the fact that all reference samples were born post 1940. Secular changes have been documented in American black and white groups with the majority of skeletal morphological changes occurring post 1940 (Jantz and Jantz 1999). Further, the majority of Hispanics in the reference sample were born post 1970. Additionally, Spradley and Hefner (2012) previously found temporal and regional variation

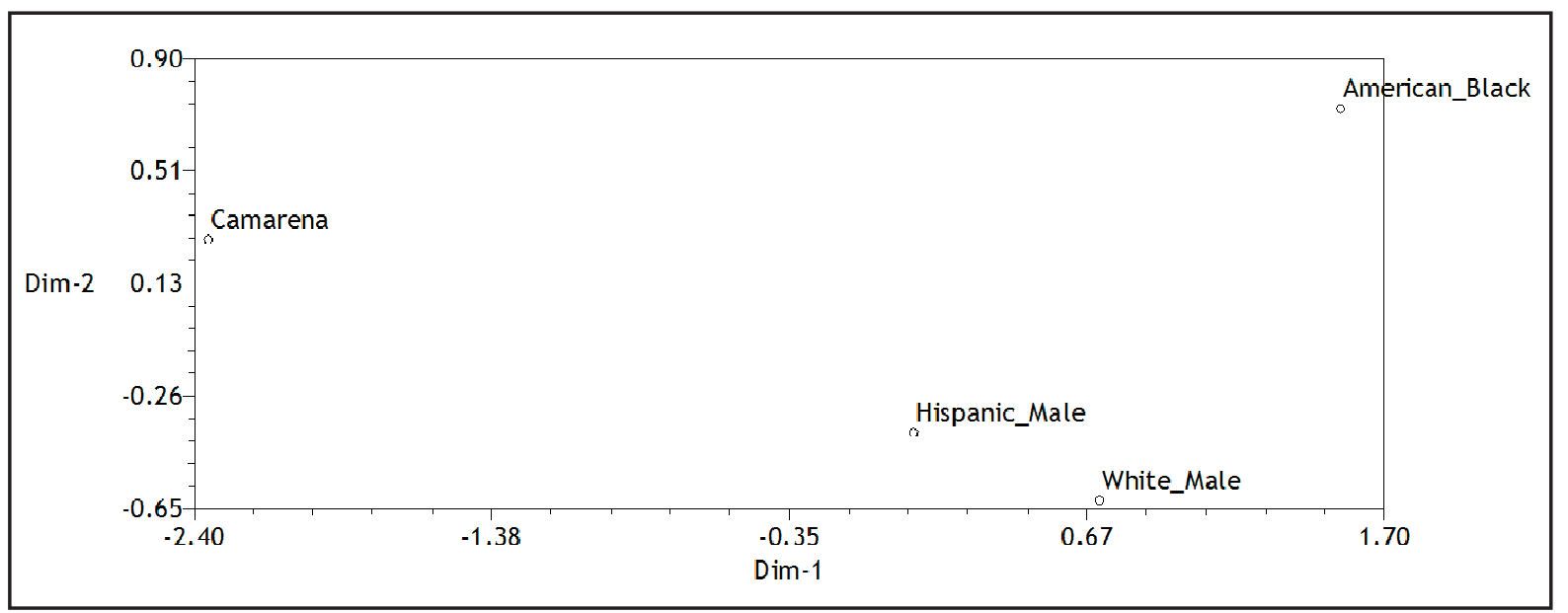

Figure 5.4. Two-dimensional plot of $\mathrm{D}^{2}$ distances. 
in Mexican migrants. Mr. Camarena, who was born in 1897 (see Chapter 3), could be a temporal outlier. Additionally, the majority of the Hispanic sample is from geographically diverse areas all over Mexico. Mr. Camarena was born in Michoacán, an area not greatly represented in the reference sample.

The overall morphoscopic features of the skeleton, including a relatively short and rounded cranial vault, moderate dental attrition, and the overall size and shape of the long bones, are also consistent with individuals from Mexico.

\section{STATURE: 5' 1/2" to 5 ' 5 1/4"}

FORDISC 3.0 (Jantz and Owsley 2005) was used for stature estimation. FORDISC uses linear regression to estimate stature based on various historic or modern reference groups. The reference sample used to generate the regression formula in this particular case is from a twen- tieth-century Hispanic sample, predominantly from Latin America. Based on the regression formula using maximum length of the clavicle and femur, and condylo-malleolar length of the tibia, the estimated stature is $5^{\prime} 1 / 2^{\prime \prime}$ to $5^{\prime} 51 / 4^{\prime \prime}$ using a 90 percent prediction interval.

\section{ORAL HEALTH: CARIOUS LESIONS AND ANTEMORTEM TOOTH LOSS}

The dentition is mostly present with several teeth missing antemortem and postmortem (Figure 5.5). Teeth 1 and 24 are missing postmortem. The soil matrix inside the cranial vault was screened for missing teeth and bone fragments. However, no additional skeletal material was found. Teeth 8,17 , and 18 are missing antemortem and exhibit full alveolar resorption. Carious lesions are present on teeth 2 and 31 . The carious lesion on tooth 2 is on the disto-occlusal surface
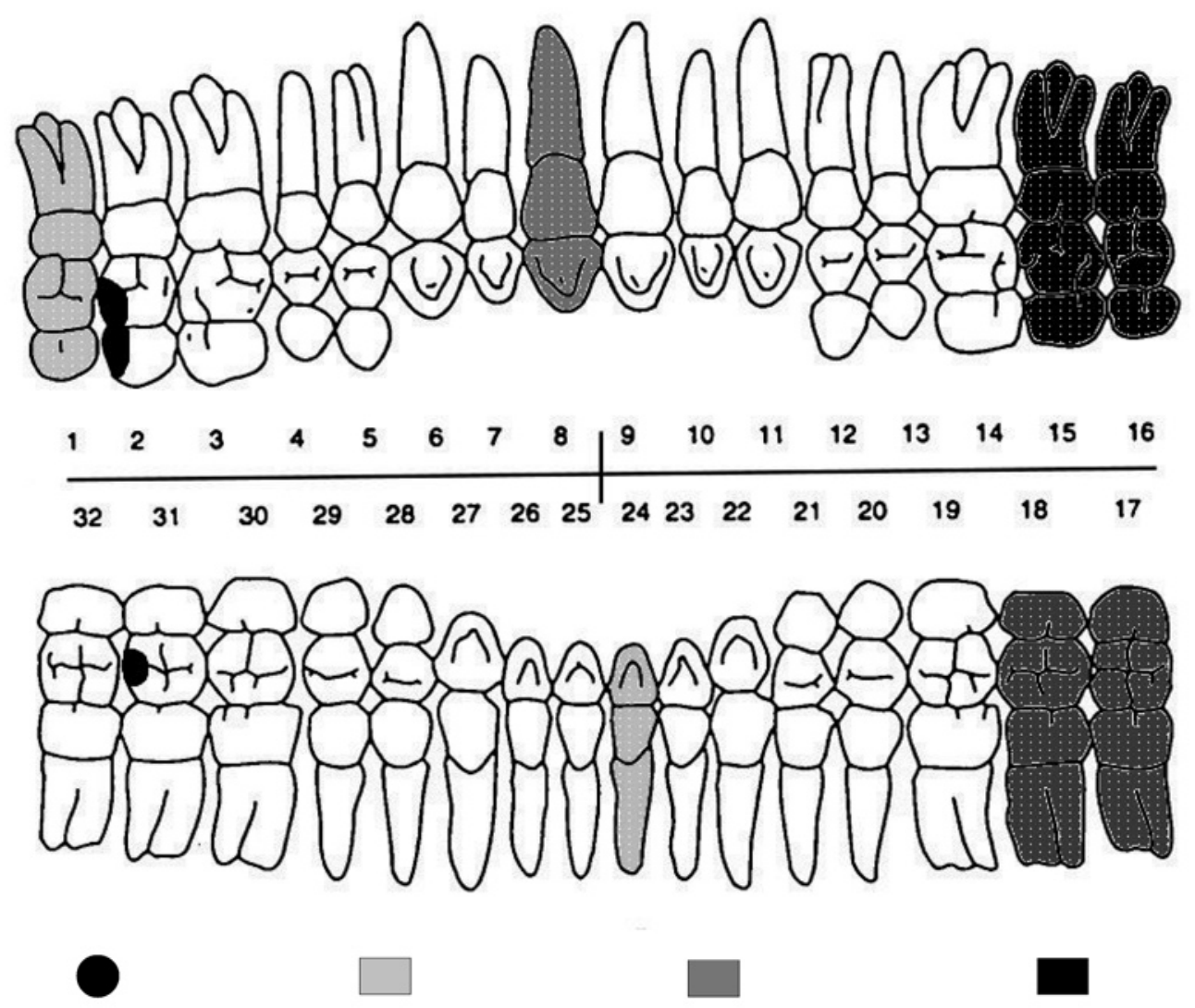
Postmortem Loss

Antemortem Loss

Alveolar bone missing

Figure 5.5. Dental inventory. 
and involves enamel destruction on the adjacent lingual surface. The carious lesion on tooth 31 is on the disto-occlusal surface.

All teeth exhibit moderate wear on the occlusal surfaces. There is slight to moderate alveolar resorption on the maxilla and mandible, although no abscesses are present. Dental calculus is noted on the buccal and labial surfaces of the majority of teeth present.

\section{PATHOLOGY AND \\ MUSCULOSKELETAL MARKERS OF STRESS}

The skeleton displays nonspecific infection, some age-related degenerative changes, marked muscle attachment sites, and possible traumatic injury. A nonspecific periosteal infection is noted on the right ulna shaft (Figure 5.6). The right ulna shaft is markedly larger than the left due to the infection.

Age-related changes manifest in the skeleton during middle adulthood and afterward, and they often occur in joint surfaces. The joint surfaces of the skeleton are in overall good condition. The right and left glenoid fossa of the scapula exhibit a slight rim, but no osteophyte spicules are present. Further, the right and left humeral heads display no rim or any signs of degenerative changes. The right and left distal humeral epiphyses both exhibit the beginning of a rim, but no major degenerative changes are observed.

The thoracic and lumbar vertebrae show signs of early osteoarthritic rim formations around the bodies with some spicule development on the lumber vertebrae. However, these degenerative characteristics are normal, agerelated changes. The cervical vertebrae (3-7) exhibit severe compression and osteophyte activity (Figure 5.7). Cervical vertebra 6 exhibits an antemortem compression fracture. The inferior articular facets of cervical vertebra 4 and the superior articular facets of cervical vertebra 5 show porosity and osteophyte activity, while the other articular facets for the cervical vertebrae are unremarkable. The degree of osteoarthritic activity in the cervical vertebrae is not seen in the thoracic or lumbar vertebrae, suggesting that the condition of the cervical vertebrae may be from traumatic injury.

The overall skeleton is robust with welldeveloped muscle attachment sites such as the

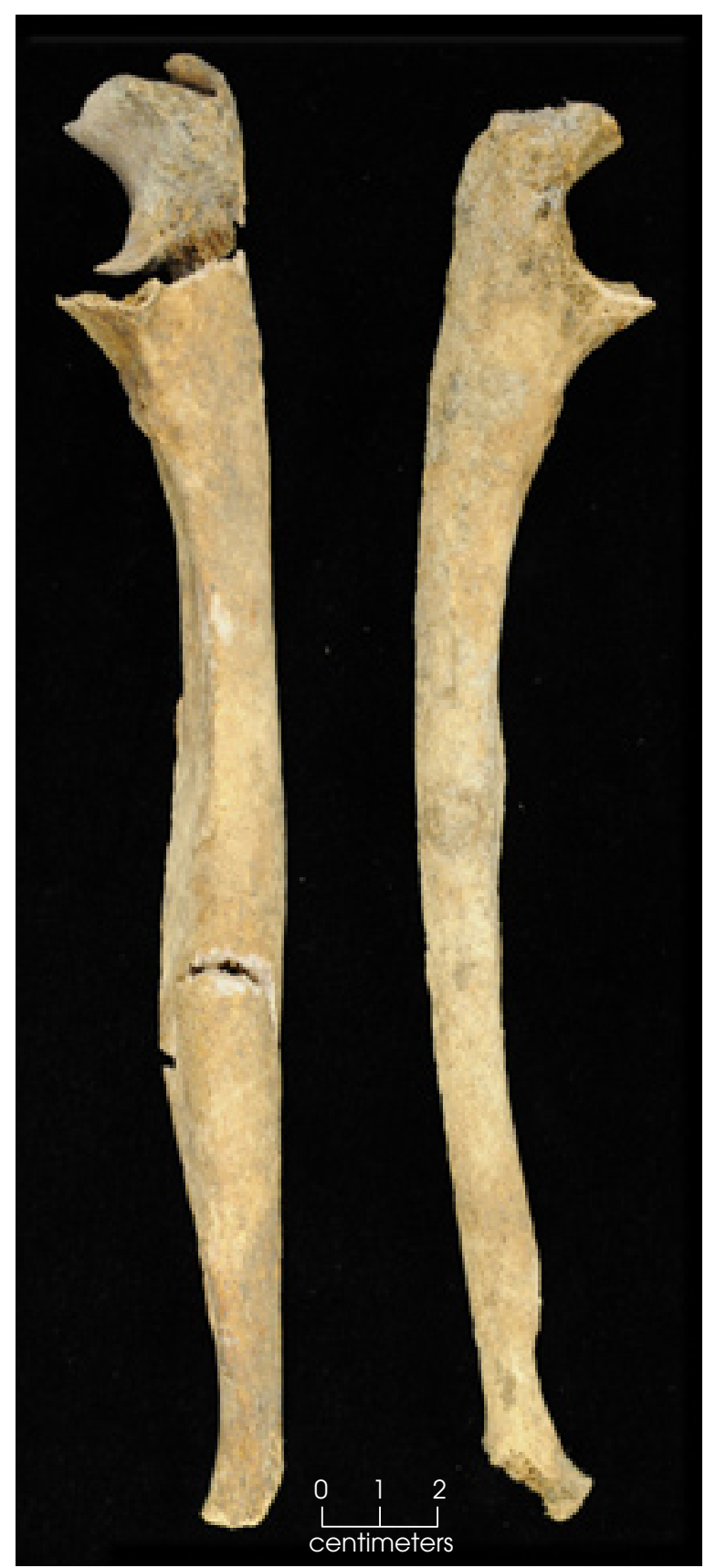

Figure 5.6. Nonspecific periosteal infection in the right ulna. Note the wider shaft in the right ulna compared to the left.

lineaaspera along the femora and the deltoid tuberosity on the humeri. Also noted is the marked development at the attachment site of triceps brachei on the humeri. The brachioradialis (flexes the forearm) and extensor carpi radialislongus (flexes the wrist) are also well developed in this individual. Enthesophytes are noted on the tibia and fibula. Enthesophytes are 

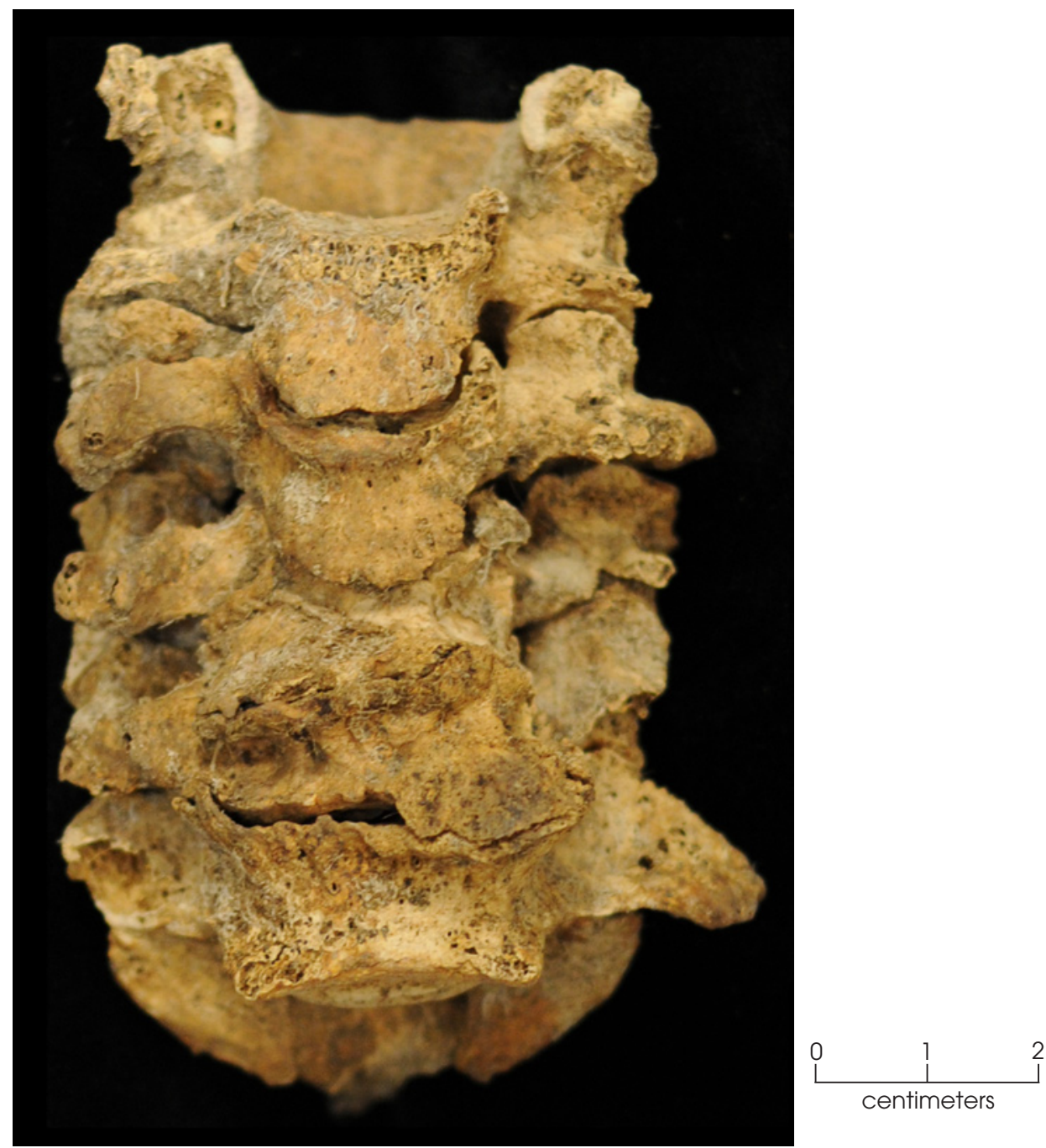

Figure 5.7. Cervical vertebrae 3-7, anterior view.

bony formations at ligament attachment sites that may result from muscle strain or traumatic injury. The posterior superior portion of the tibial shaft has an enthesophyte at the attachment site for the soleus (involved in plantar flexion). An enthesophyte is also noted on the posterior surface of the distal articular facet of the fibula.

\section{CONCLUSION}

The human remains brought to the Department of Anthropology at Texas State University for analysis are entirely consis- tent with the biographical profile of Salvador Camarena (see Chapter 3). The archival record verifies that Camarena was from Michoacán de Ocampo, Mexico, and was 53 or 54 years old when he died. The skeletal remains represent a male, most similar to modern Mexicans, who stood approximately 5' $1 / 2$ " to 5' 5 1/4" tall, with an estimated age at death of 40-50 years. The pupae casings in the cranial vault are consistent with the reported delayed burial of the body. There is no perimortem trauma on the skeletal remains that suggests cause or manner of death. 


\title{
SALVADOR CAMARENA AND THE PLIGHT OF MIGRANT WORKERS
}

6

\author{
Douglas K. Boyd and Amy E. Dase
}

\begin{abstract}
...Braceros had children here, lived and died here, and fought for their rights here... Like other immigrants, both documented and not, they became a part of the fabric of American life. ${ }^{10}$

In the often heated debate over immigration and undocumented workers in the United States, one voice has been noticeably missing-the voice of the migrants themselves. ${ }^{11}$
\end{abstract}

\section{THE FATE OF SALVADOR CAMARENA}

The documents he carried suggest that Salvador Camarena considered Morelia, Michoacán, home until his death. At a minimum, Camarena had traveled between Morelia and the United States three times: by 1918 when he worked in Chicago, in 1928 when he crossed at Brownsville, and in 1950 when he died, stranded in a Texas pasture. His specific destinations in Texas remain unknown, but he frequently trekked to various locations for short-term employment as a migrant worker, according to family members. He may have stayed close to the border in the "Winter Garden area" with Crystal City, Texas, at its heart, where spinach, beet, onion, and cotton crops flourished in the 1920s and $1930 \mathrm{~s}$, or he may have journeyed substantially farther, following the seasonal harvest of crops in other states (Menefee 1941:xiii, 1-10). How often and where he crossed the border when his travels were undocumented, as was the case

\footnotetext{
10 Jennifer Osorio (2005:102).

11 Russell Guerrero, as cited in Berruecos (2011:223)
}

in 1950 , are also uncertain. ${ }^{12}$ Like thousands of Mexican nationals, Camarena worked as a seasonal agricultural laborer to provide for his family, but he never intended to permanently settle on American soil or considered United States citizenship. Mexico was home.

The circumstances of Camarena's death will always be a mystery. Was he traveling alone? How did he die? When was his family notified, and by whom? To pay tribute to their relative, his sisters and wife had a memorial-a descanso-placed at his grave, and the sisters visited the site with his niece.

Camarena's grave may have been isolated, but his fate was not. Many Mexican nationals died while traveling to and from temporary positions working in agricultural fields for low wages. A 1956 photograph depicts braceros passing the grave of an unknown fellow worker along the railroad tracks (Figure 6.1). A wood cross and rock pile mark the burial near the Monterrey Processing Center in Mexico, where braceros signed labor contracts before traveling to jobs in Texas through one of several border towns. The image is a poignant reminder of the attendant risks migrants took to work in the United States.

Upon his death, Camarena was carrying an identification card that may have been a Mexican passport or an alien laborer permit or identification document, also known as a bracero card, for legally contracted workers, which the U.S. Immigration and Naturalization Service issued (Figure 6.2). These cards noted the date,

12 Lilia Manriquez Flores believed that her uncle Salvador was traveling from Mexico to Texas City to visit relatives in 1950 (James Crowder, Jr., personal communication 2014) 


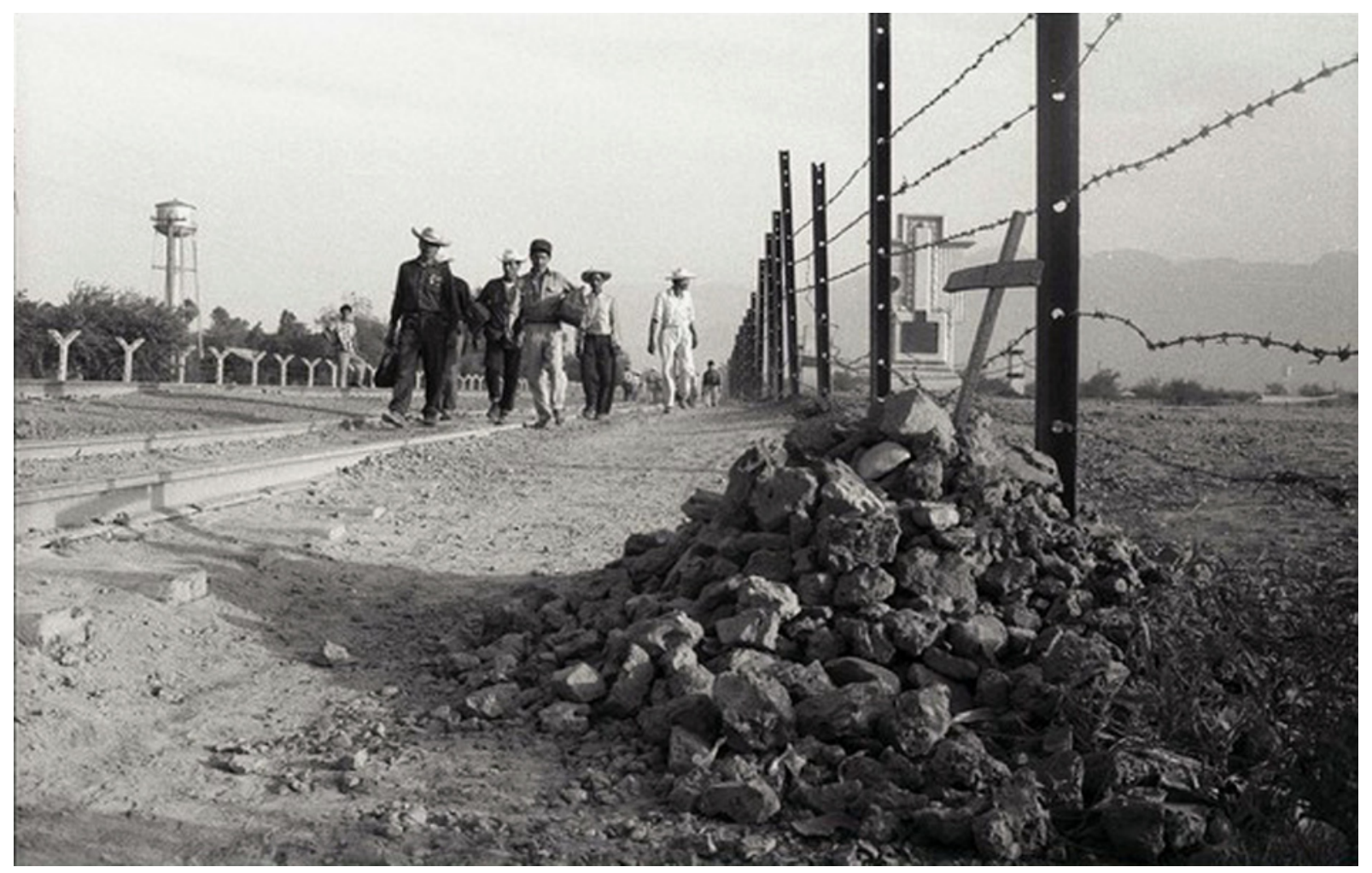

Figure 6.1. Leonard Nadel photographed this bracero grave along the railroad tracks near the Monterrey Processing Center in 1956 (Nadel 1956).

port of issuance, card number, and the alien's name, age, marital status, height, physical marks, last residence, and literacy. Each card had a photograph, destination, and employer's name, and the following text: "The bearer, a native and citizen of Mexico, has this day been granted the privilege of temporarily entering the United States in accordance with and under the conditions of Department [of Labor] circular of June 12, 1918, as amended." Camarena's identification card had enough information to link him to his family of origin in Morelia, but did not seem to specifically classify him as a migrant worker, although his son and niece described him as such. Given the remote location of his death and that several days passed before his body was discovered, Camarena may have been intentionally traveling cross-country instead of along a public road where hitching a ride to his destination would have been possible. Not surprisingly, undocumented migrant workers usually walked to their destinations to avoid people and the possibility of being deported (Spener 2004:297).

\section{BRIEF HISTORY OF MIGRANT LABORERS}

The complex history of migrant labor has affected millions of Mexican nationals like Camarena since the nineteenth century. For decades, most Mexican nationals who toiled in the United States were undocumented. An estimated 70,000 undocumented workers were in the country in 1848. An 1885 law prohibited importing contract laborers, but Mexicans were free to enter or leave the United States at will to visit, work (just not on contract), or settle (Cohen 2001:115-116; McCain 1981:45). A 1917 immigration law required newcomers to pass a literacy test and pay a head tax, closing what had been an open U.S.-Mexico border. Immediately, Mexicans began to enter the United States surreptitiously. The term "wetback" characterized those who waded the Rio Grande to evade the restrictions (McCain 1981:46). The U.S. government often used the derogatory term in its official capacity. In the aftermath of World War I, the government suspended contract- 

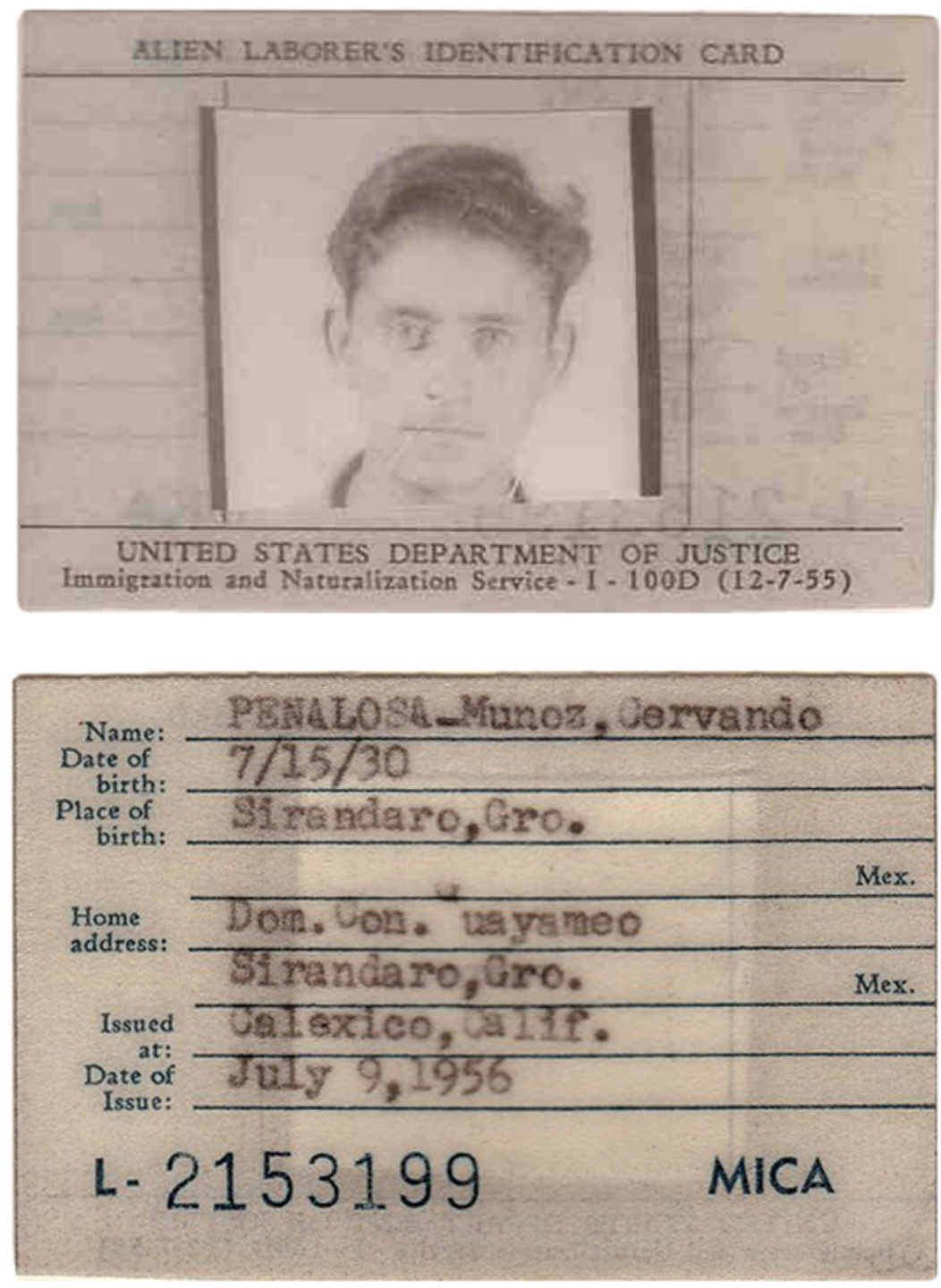

Figure 6.2. The front and back of the alien laborer identification card issued to Servando Panaloza Munoz on July 9, 1956 (Bracero History Archive 2014b).

labor, literacy test, and head-tax provisions for Mexican workers until 1921. Because of the overall benefits of jobs for its citizens, the Mexican government had conceded to low wages and poor conditions for their citizens, had no restrictions on emigration, and did not prevent workers from migrating (McCain 1981:46). Texas farmers consistently defied the contract labor law until the 1924 establishment of the U.S. Border Patrol (McCain 1981:46; Scruggs 1961:150). But the underfunded Border Patrol was constantly coerced to "relax its vigilance" at harvest time. Growers believed they had rights to cheap labor, and they favored aliens, whose unlawful status forced them to consent to low wages (Scruggs 1961:150). Growers suffered no penalties for hiring undocumented workers (Scruggs 1961:149).

During the Great Depression of the 1930s, seasonal migration from Mexico to Texas declined. Low wages, poor conditions, and the lack of jobs discouraged migration, and the Mexican government increased opposition to migration (McCain 1981:47). The number of illegal workers was relatively small and generally confined to border areas; however, a possible 10,000 and 13,000 were still apprehended annually (Scruggs 1961:151). 
By 1940, the Mexican government was no longer passive about emigrations and the poor treatment its citizens received laboring in the United States. A deficit of manual laborers at the onset of World War II prompted the United States and Mexico to enter into a series of contract labor agreements. Those Americans who ordinarily would have been farm laborers joined the military or worked to support the war effort in industrial employment (McCain 1981:48). American farmers hired foreign workers for seasonal employment to fulfill the shortage of farmworkers; however, during the war fewer than 1 percent of contracted seasonal workers were Mexican nationals (Grove 1996:309, 310). Texas was an obvious destination for migrant workers, but the Mexican government denied sending braceros to Texas until 1947 (Navarro 2005:242-244). The consul general characterized the state's prevailing Jim Crow conditions as "exceptional circumstances" that required "exceptional measures" to protect the laboring class (Montejano 1987:268). Mexico's refusal to allow legal entry of workers, however, encouraged their illegal entry, and lax borders on the American side let the flow persist (McCain 1981:62-63). Of the 219,540 Mexican national workers who entered the United States legally between 1942 and 1947, none came to Texas (McCain 1981:64).

As a result, most Mexican national migrant workers in Texas, like Camarena, were undocumented and in the state illegally during and after the war. Thousands of Mexican nationals, virtually unhindered, crossed the border surreptitiously. Instead of making public demands for braceros, Texas farmers intensified directly recruiting laborers to whom they promised work. Texan employers preferred illegal migrant workers because they accepted lower pay than their legitimate counterparts and were reliable and hardworking. These workers also tolerated poor living and working conditions without complaint for fear of losing their jobs. The Mexican government prohibited braceros from entering Texas but did little to stop their movement. The program fostered breaking the law since many workers preferred the informality of illegal entry because the bracero program involved delays to obtain papers and red tape to overcome with quotas, physical examinations, and security checks. Of course, they had no protection like wage or housing guarantees without legal entry.
"Domestic critics could blame the Mexican government for ills that might befall workers if it approved their employment in Texas; but they could not hold it responsible for workers' being exploited or discriminated against if they were in Texas illegally, for the Mexican government steadfastly opposed and denied any responsibility for such migration." Finally, in September 1947, the United States legalized the status of an estimated 100,000 undocumented immigrants in Texas and the Southwest before terminating the bracero program until 1951 (McCain 1981:60-64; Scruggs 1961:163).

After the war, thousands of tenant farmers and sharecroppers left their rural roots to seek opportunity in larger towns and cities. This exodus intensified reliance on seasonal workers, particularly in the cotton fields, where yields rose sharply and the work was seasonal (Grove 1996:308). A revised version of the bracero program was put in place. Between 1955 and 1959 , an annual average of 484,000 braceros worked on American farms-18 percent of all seasonal farm laborers (Grove 1996:310). Many Mexican nationals crossed the border legally to take advantage of guarantees the program offered, but even more stayed beyond harvest season after their contracts had expired or subsequently returned without passing through an authorized port of entry. Evidently, the bracero program still could not provide enough workers to supply demand or give jobs to the large number of Mexicans who wanted to work in the United States. As a result, the program encouraged illegal migration.

Regardless of their legal status, migrant workers toiled at physically demanding jobs, endured harsh living conditions, faced overt discrimination practices, and suffered the difficulties of their absence from family at home in Mexico. Crude housing might be employerprovided; otherwise, migrants squatted on public land or rented from the owner. Some one- or two-room houses were of lumber, but more were patched together with scraps of material and had dirt floors and lean-to kitchens. Housing rarely had electricity or indoor plumbing. Overcrowding and poor sanitation conditions allowed disease, particularly tuberculosis, to spread easily, and medical services were either not available to Mexican nationals or were too expensive. Access to education was impossible. Hindered by the language barrier and spotty 
school attendance, since children were often working in the fields, illiteracy was the norm (Menefee 1941:xv, 41-43).

Figure 6.3 provides statistics on Mexican immigration to the United States between 1942 and 1964. Hernández gives slightly different numbers of undocumented worker apprehensions the Border Patrol made between 1949 and 1953 (Hernández 2006:440, 441). She cites the numbers as: 279,379 in $1949 ; 459,289$ in 1950; 501,713 in 1951; and 827,440 in 1953. Hernández does cite the same number of apprehensions in the fiscal year 1954 (at 1,089,583). That year Border Patrol initiated "Operation Wetback," a program to apprehend and deport more than one million illegal immigrants, most of whom were Mexican citizens (Hernández 2006:421). In an effort to retain laborers essential to its own agricultural economy, the Mexican government supported Operation Wetback, a "campaign of aggressively targeting Mexican nationals for interrogation, apprehension, and deportation" (Hernández 2006:429). Hernández also notes that between 1949 and 1954 one-third of all apprehensions were "repeat offenders" who had been deported previously (Hernández 2006:440).

The number of undocumented workers in the United States who were not apprehended between 1942 and 1964 is not known. In 1952, 1.5 million undocumented workers were in the country (Cohen 2001:115-116). If this is accurate, for every legal bracero program worker, there were 7.6 undocumented workers. Thus, for every worker apprehended and deported, many more successfully entered the United States. In 1949 and 1950, the number of undocumented worker apprehensions was 2.7 to 6.9 times higher than the number of legal bracero workers (see Figure 6.3). The number of illegal crossings was probably many times higher. Thus, historically and statistically speaking, Camarena was most likely an undocumented worker rather than a participant in the bracero program when he died in Texas in 1950.

\section{THE ONGOING SAGA OF BORDER-CROSSING DEATHS}

In 2009, Doris Meissner, then a U.S. Immigration and Naturalization Service commissioner, observed that deaths are "a tragic byproduct of border enforcement" (as quoted in

\begin{tabular}{|lrrr|}
\hline \multicolumn{4}{|c|}{$\begin{array}{l}\text { Mexican Immigration to the } \\
\text { United States, 1942 to 1964 }\end{array}$} \\
\hline & & \multicolumn{3}{c|}{ Mexican } \\
Year & Braceros & Apprehensions & Immigrants \\
& & & \\
1942 & 4,203 & 11,784 & 2,378 \\
1943 & 52,098 & 11,175 & 4,172 \\
1944 & 62,170 & 31,174 & 6,598 \\
1945 & 49,454 & 69,164 & 6,702 \\
1946 & 32,043 & 99,591 & 7,146 \\
1947 & 19,632 & 193,657 & 7,558 \\
1948 & 35,345 & 192,779 & 8,384 \\
1949 & 107,000 & 288,253 & 8,803 \\
1950 & 67,500 & 468,339 & 6,744 \\
1951 & 192,000 & 509,040 & 6,153 \\
1952 & 197,100 & 528,815 & 9,079 \\
1953 & 201,380 & 885,587 & 17,183 \\
1954 & 309,033 & $1,089,583$ & 30,645 \\
1955 & 398,650 & 254,096 & 43,702 \\
1956 & 445,197 & 87,696 & 61,320 \\
1957 & 436,049 & 59,918 & 49,321 \\
1958 & 432,857 & 53,474 & 26,721 \\
1959 & 437,643 & 45,336 & 22,909 \\
1960 & 315,846 & 70,684 & 32,708 \\
1961 & 291,420 & 88,823 & 41,476 \\
1962 & 194,978 & 92,758 & 55,805 \\
1963 & 186,865 & 88,712 & 55,986 \\
1964 & 177,736 & 86,597 & 34,448 \\
Total & $4,646,199$ & $5,307,035$ & 545,941 \\
\hline
\end{tabular}

Figure 6.3. Table of Mexican immigration statistics from an online publication of the Center for Immigration Studies (May 2001).

Kovic 2013:19). Crossing the U.S.-Mexico border has always been a risky proposition for migrants traveling on foot, and the death of Salvador Camarena is far from an isolated case. Referring to the border situation in the 1940 s and $1950 \mathrm{~s}$, Hernández notes that government tactics to control illegal migration became increasing sophisticated and violent (Hernández 2006:433-440). The intent to intimidate Mexican workers so they would stop attempting to cross the border did not stop the flow of illegal migrants; rather, it forced the movement of workers to become even more furtive-and dangerous. More illegal migrants turned to hiring "coyotes" 13 to assist

\footnotetext{
13 Coyotes are people who guide illegal migrants across the U.S.-Mexico border for a fee (Spener 2009). Once mainly done by locals living along the border, the business of smuggling workers has been steadily taken over by organized crime.
} 
them across the border. Increased demand for coyotes' services opened the door for organized crime and other unscrupulous entrepreneurs to enter into human smuggling. The result was a rise in border-crossing deaths, accidental and otherwise. "With fences and coordinated surveillance, U.S. and Mexican officers pushed those who dared to cross the border without sanction into the backlands and waters of the border landscape....Their deaths...were a reminder of the most extreme consequence of being policed" (Hernández 2006:4).

How to deal with the illegal migrants crossing Mexico's northern border to seek work in the United States has long been a topic of political and economic debate between and within the two countries. The problems are as real today as they were throughout the twentieth century. Because of current restrictive migration policies and the weak Mexican economy, thousands of undocumented migrants still regularly cross the border to find work, despite increased border security. Spener (2004:296-297) notes that:

Rather than abandoning the attempt to enter the United States without authorization, however, migrants have begun crossing in less guarded stretches of the border. These are in remote, rural areas where after crossing the international line migrants must frequently walk long distances through desert, brush, and/ or mountains to evade immigration checkpoints on the main highways leading away from the border. In some areas, these journeys can take several days or even a week and can be deadly in times of extreme temperatures or flooding of the Rio Grande/Rio Bravo. Since 1993 the number of deaths of migrants attributable to drowning, hypothermia, dehydration, or heat stroke has risen markedly to several hundred per year.

The death rate per 100,000 unauthorized crossings made by Mexicans tripled between 1993 and 1998, but even this "does not appear to have substantially reduced the overall number of attempts migrants make to enter the U.S." (Spener 2004:297).
Border crossings by migrant workers have always been dangerous, but they are perhaps more so now than ever before. A study published in 2013 is titled Searching for the Living, the Dead, and the New Disappeared on the Migrant Trail in Texas: Preliminary Report on Migrant Deaths in South Texas. Prepared for the Prevention of Migrant Deaths Working Group of the nonprofit organization Houston United/Houston Unido, it states that around 5,000 migrants died in border crossings between 1998 and 2013, according to the U.S. Department of Homeland Security (Christine Kovic 2013:4). Kovic (2013:4-5) goes on to conclude the following:

- "Recorded deaths of border crossers in Texas are at an all-time high" (in 2012).

- The southern border of the United States "is becoming more deadly" for border crossers even though the number of migrants crossing is declining.

- "Migrant deaths in Texas are concentrated in Brooks County where 129 migrant bodies were recovered last year" (in 2012).

- "Migrants are dying as they cross the harsh desert terrain" attempting to avoid the Customs and Border Patrol checkpoints.

- "DNA testing, as required by Texas State Law for all unidentified remains, is not being carried out in a standardized and coordinated manner to identify the dead."

- "Migrant deaths have become the metrics of a failed border security policy."

Of the three states along the southern border, Texas led in the number of bordercrossing deaths in 2012 by a significant margin, and most of these deaths occurred in the Lower Rio Grande Valley. The official stance may be to downplay or even ignore these border-crossing deaths (Kovic 2013), but some efforts are being made to identify and study the skeletal remains of migrant laborers found in the Texas. In 2002, Dr. Lori Baker, a forensic anthropologist at Baylor University, established "Reuniting Families" program to help identify the remains of migrant workers who died inside the U.S. border. The group examines human skeletons and personal effects found with bodies, compares X-rays and dental records, and uses DNA and other techniques 
to identify remains and find relatives. Since then, the program has been successful in identifying remains and reconnecting families in many cases. The group collaborates with the Mexican government to link people searching for missing relatives with the DNA database for migrant worker remains. Baker summed up her philosophy by stating, "I believe all life is sacred, and it seems my duty to give dignity to these individuals by giving them a name" (as quoted in Chakrabarti 2013).

In 2013, forensic anthropologists Dr. Spradley (Texas State University, one of the authors of this report), Dr. Baker (Baylor University), and Dr. Krista Latham (University of Indianapolis) began collaborating to identify and examine skeletal remains of 60 individuals recovered from Brooks County (Baker 2013; Department of Anthropology, Texas State University 2014; MyFOXaustin 2013). The increase in the number of illegal migrant deaths in the county had jumped from 29 in 2012 to 129 in 2013 (MyFOXaustin 2013). For each set of remains, this volunteer effort includes an examination to create a biological profile (stature, age, sex, and ancestry), documentation of personal items with each body and a search for identifying clues, and collection of a small sample of bone for future DNA analysis. The goals are to identify the remains and return them to their families if possible. As Spradley notes, however, "It's kind of like looking for a needle in a haystack. You may have somebody that crossed the border with one of these individuals, and they may come forward" (as quoted in Baker 2013).

The history of official Mexican and United States immigration policies has been studied and debated at great length, but the effects these policies have had on the lives and deaths of Mexican migrant workers, both illegal and legal, are topics that have received little attention from politicians, historians, or other researchers. Some ongoing efforts to better document the lives of braceros and undocumented migrant workers and educate the public include the Smithsonian Institution's traveling exhibit called "Bittersweet Harvest: The Bracero Program, 1942-1964" (Smithsonian Institution 2010). Another example is the online Bracero History Archive, which collects and disseminates information about the Mexican workers who signed official labor contract agreements be- tween 1942 and $1964 .{ }^{14}$ The bracero program has received more attention lately as the U.S. and Mexican governments have looked at changing their immigration and border policies:

Current debates about immigration policy_including discussions about a new guest worker program-have put the program back in the news and made it all the more important to understand this chapter of American history. Yet while top U.S. and Mexican officials re-examine the bracero program as a possible model, most Americans know very little about the program, the nation's largest experiment with guest workers. Indeed, until very recently, this important story has been inadequately documented and studied, even by scholars (Bracero History Archive 2014a).

The bracero program was a reasonable legal mechanism for encouraging migrant laborers that failed, with a flood of illegal migrants overwhelming the trickle of documented workers. Migrant workers gave the program mixed reviews. "The braceros experienced exploitation but also opportunity...The work was grueling, the time spent away from home difficult, but the opportunity to earn money was real. The program was truly bittersweet" (Peter Liebhold in 2008, as quoted in Smithsonian 2010).

The history of illegal migrant workers is even more neglected than that of the bracero program. Certainly it is more difficult to document and study the lives and deaths of illegal migrant laborers, but their histories are important and should have a bearing on current immigration policy debates.

While these debates go on, real people crossing the border to look for work suffer and die because of politics and policies. "Even the border patrol will admit that 98 percent of undocumented immigrants are not drug dealers or

\footnotetext{
14 According to the website, "The Bracero History Archive is a project of the Roy Rosenzweig Center for History and New Media, George Mason University, the Smithsonian National Museum of American History, Brown University, and The Institute of Oral History at the University of Texas at El Paso. Funding provided by the National Endowment for the Humanities" (Bracero History Archive 2014a).
} 
criminals, but hard working people looking for a job so that they can provide for their families. They go through the desert because they have to; they risk their lives because they are looking for work...." (Groody 2004:60-61).

From a historical perspective, the death of Salvador Camarena represents a small piece of the complex and ongoing story of U.S.-Mexico border relations since the nineteenth century. Although his remains were carefully exhumed and reinterred near those of his family, untold numbers of migrant workers have died and remain in isolated graves dotted across the landscape. Their families still agonize over the uncertainty of not knowing what happened to their loved ones. Even so, enough incentives exist to compel Mexico nationals and other Latin American migrant workers to come to the United States seeking jobs and a better life. They will continue to cross the border, legally or illegally, despite knowing the dangers they will face. Border-crossing deaths will continue to be a part of the story, a human toll paid by some unfortunate migrant workers, while Mexico and the United States continue to debate immigration policies. 


\section{REFERENCES CITED}

Baker, Rebecca

2013 Researching Remains: Forensic Anthropology Center Attempts to Identify Skeletons of Migrants. The University Star 103(17):1. October 1, 2013. Texas State University, San Marcos. Electronic document, http://issuu.com/universitystar/docs/ october_1_2013/1, accessed May 8, 2014.

Berruecos, Luis

2011 Review of Clandestine Crossings: Migrants and Coyotes on the Texas-Mexico Border by David Spener. Review by Luis Berruecos. Contemporary Sociology 40(2)223-224 (March 2011).

Boston University

2014 A Brief Timeline of Polaroid. Photographic Resources Center at Boston University. Electronic document, http://www.bu.edu/ prc/forms/polatimeline.pdf, accessed June 11, 2014.

Bosveld, Jane, and Amy Barth

2010 Fatal Crossings: The Lives That End at America's Desolate Border. Discover Magazine, July_August 2010. Electronic document, http://discovermagazine. com/2010/jul-aug/23-fatal-crossing-livesend-way-into-america, accessed May 8, 2014.

Bracero History Archive

2014a About the Bracero History Archive. Electronic document, http://braceroarchive.org/about, accessed April 30, 2014.

2014b Images of Front and Back Sides of Alien Laborer's Identification Card of Servando Panaloza Munoz, issued July 9, 1956 by the United States Department of Justice, Immigration and Naturalization Service. Bracero History Archive, Items 880 and 881. Electronic documents, http://braceroarchive.org/es/items/show/880 and http:// braceroarchive.org/es/items/show/881, accessed April 30, 2014.
Brading, D. A.

2001 Mexican Phoenix: Our Lady of Guadalupe: Image and Tradition Across Five Centuries. Cambridge University Press, Cambridge, United Kingdom.

Buikstra, J. E., and D. H. Ubelaker (editors)

1994 Standards for Data Collection from Human Skeletal Remains: Proceedings of a Seminar at the Field Museum of Natural History. Arkansas Archaeological Survey, Fayetteville.

Chakrabarti, Meghna (host)

2013 Anthropologist Works to Return Migrants' Remains. Here \& Now. Transcript of National Public Radio program, November 21, 2013. Electronic document, http://hereandnow.wbur.org/2013/ 11/21/return-migrants-remains, accessed May 8, 2014.

Cohen, Deborah

2001 Caught in the Middle:The Mexican State's Relationship with the United States and Its Own Citizen-Workers, 1942-1954. In Migration and the Making of North America. Journal of American Ethnic History 20(3):110-132.

Department of Anthropology, Texas State University 2014 Current Projects: Identifying Migrant Deaths in Texas. Department of Anthropology, Texas State University. Electronic document, http://www.txstate. edu/anthropology/people/faculty/spradley/ Current-Projects, accessed May 8, 2014.

E.U. Mexicano, Departmento de la Estadistica Nacional, Direccion de Censos

1930 Morelia City, Michoacán, manuscript population schedule. Electronic document, http://search.ancestry.com/cgi-bin/sse. $\mathrm{dll} ? \mathrm{~h}=9778629 \& \mathrm{db}=1930 \mathrm{MexicoCensus} \&$ indiv=try, accessed February 27, 2012. 
FamilySearch

2012a Abran [sic] Manriquez, Texas Deaths, 1890-1976. Electronic document, https:// familysearch.org/pal:/MM9.1.1/JDVC-1QS, accessed February 27, 2012.

2012b Lilia Manriquez, Texas Birth Index, 1903-1997. Electronic document, https:// familysearch.org/pal:/MM9.1.1/VDGV-F41, accessed February 27, 2012.

Farmers' Almanac

1950a Weather History Results for Eagle Pass, Texas, January 1950. Electronic document, http://www.farmersalmanac.com/weather-history/78852/1950/01/04, accessed February 27, 2012.

1950b Weather History Results for Eagle Pass, Texas, January 1950. Electronic document, http://www.farmersalmanac.com/weather-history/78852/1950/01/05, accessed February 27, 2012.

1950c Weather History Results for Eagle Pass, Texas, January 1950. Electronic document, http://www.farmersalmanac.com/weather-history/78852/1950/01/06, accessed February 27, 2012.

Find A Grave

2012 Find A Grave, s.v. "Margarita Camarena Manriquez." Electronic document, http:// www.findagrave.com, accessed February 6 , 2012.

Galveston Daily News, The

1982 Margarita Manriquez. The Galveston Daily News, October 2, 1982.

Groody, Daniel

2004 Crossing the Line: A Spiritual View of the US-Mexican Border. The Way 43(2):5869. Electronic document, http://www3. nd.edu/ dgroody/Published\%20Works/ J o u r n a l\% $20 \mathrm{Articles/files/}$ CrossingtheLine_theWay.pdf, accessed April 8, 2014.

Grove, Wayne A.

1996 "The Mexican Farm Labor Program, 1942-1964: Government-Administered Labor Market Insurance for Farmers." Agricultural History 70(2):302-320.

Hernández, Kelly Lytle

2006 The Crimes and Consequences of Illegal Immigration: A Cross Border Examination of Operation Wetback, 1943-1954. Western Historical Quarterly 37 (2006):421-444.

Jantz L., and R. L. Jantz

1999 Secular Change in Long Bone Length and Proportion in the United States, 1800-1970. American Journal of Physical Anthropology 110:57-67.

Jantz, R. L.

2010 Advanced Laboratory Methods in Forensic Anthropology. Workshop held at The Univerity of Tennessee.

Jantz, R. L., and P. H. Moore-Jansen

1988 A Data Base for Forensic Anthropology: Structure Content and Analysis. Department of Anthropology, The University of Tennessee, Knoxville.

Jantz R. L., and S. D. Owsley

2005 FORDISC 3.0: Personal Computer Forensic Discriminant Functions. The University of Tennessee, Knoxville.

Kovic, Christine

2013 Searching for the Living, the Dead, and the New Disappeared on the Migrant Trail in Texas: Preliminary Report on Migrant Deaths in South Texas. Report for Houston United/Houston Unido. Electronic document, http://prtl.uhcl.edu/ portal/page/portal/HSH/HOME/HSH $\% 20$ Programs/Anthropology/pdfs/Final\%20 Report\%206\%205\%2013.pdf, accessed March 31, 2014.

Lovejoy, C. O., R. S. Meindl, T. R. Pryzbeck, and R. P. Mensforth

1985 Chronological Metamorphosis of the Auricular Surface of the Ilium: A New Method for the Determination of Adult Skeletal Age at Death. American Journal of Physical Anthropology 68:15-28.

May, Philip Martin

2001 There Is Nothing More Permanent Than Temporary Foreign Workers. In Backgrounder 5-01, April 2001. Online publication of the Center for Immigration Studies. Electronic document, http://cis. org/TemporaryWorkers-Overstays, accessed May 13, 2014.

McCain, Johnny M.

1981 "Texas and the Mexican Labor Question, 1942-1947." The Southwestern Historical Quarterly 85(1):45-64. 
Menefee, Selden C.

1941 Mexican Migratory Workers of South Texas. U.S. Government Printing Office for the Federal Works Agency, Work Projects Administration, Division of Research, Washington, D.C. Electronic document, http://texashistory.unt.edu/ark:/67531/ metapth5839/, accessed July 8, 2014.

Montejano, David

1987 Anglos and Mexicans in the Making of Texas, 1836-1986. University of Texas Press, Austin.

MyFOXaustin

2013 Texas State Students Help ID Remains of Border Crossers. MyFOXaustin. Posted September 16, 2013. Electronic document, http://www.myfoxaustin.com/ story/23448112/students-at-texas-statehelp-id-remains-of-border-crossers, accessed May 8, 2014.

Nadel, Leonard

1956 "Braceros, Walking from the Mexican Town of Monterrey to the Processing Center Three Miles Away, Pass the Grave of a Fallen Compatriot." Photograph in the Bracero History Archive, Item No. 1580. Electronic document, http://braceroarchive. org/items/show/1580, accessed April 30, 2014.

Navarro, Armando

2005 Mexicano Political Experience in Occupied Aztlán: Struggles and Change. AltaMira Press, Walnut Creek, California.

Osorio, Jennifer

2005 Proof of a Life Lived: The Plight of the Barceros and What it Says About How We Treat Records. Archival Issues 29(2):95-103.

Ringstaff, Christopher W.

2011 Abandoned Cemetery Investigation on FM 481, Maverick County, Texas. Interim Survey Report for Intensive Archeological Survey, CSJ No. 159003-965. Archeological Studies Program, Environmental Affairs Division, Texas Department of Transportation, Austin.

\section{Sanborn Map Company}

1931 Texas City, Galveston County, Texas, 1931. Sanborn Map Company, New York. Electronic document, Digital Sanborn Maps, 1867-1970, ProQuest subscription database, accessed February 27, 2012.
Scruggs, Otey M.

1961 "The United States, Mexico, and the Wetbacks, 1942-1947." Pacific Historical Review 30(2):149-164.

Shoe and Leather Reporter

1921 "Will Install New Conveyor Outfit." Shoe and Leather Reporter 144(1).

Shugart, Cooksey, Tom Engle, and Richard E. Gilbert

2003 Complete Price Guide to Watches, No. 23 Cooksey Shugart Publications, Cleveland, Tennessee.

Smithsonian Institution

2010 Bittersweet Harvest: The Bracero Program, 1942-1964. Exhibit description by the Smithsonian Institution Traveling Exhibition Service, Washington, D.C. Electronic document, http://www.sites. si.edu/exhibitions/exhibits/bracero_project/main.htm, accessed April 2, 2014.

Spener, David

2004 Mexican Migrant-Smuggling: A CrossBorder Cottage Industry. Journal of International Migration and Integration 5:295-320.

2009 Clandestine Crossings: Migrants and Coyotes on the Texas-Mexico Border. Cornell University Press, Ithaca, New York.

Spradley, M. K., and J. T. Hefner

2012 Secular Change in Hispanic Crania. American Journal of Physical Anthropology 147:275.

Suchey, J. M., and D. Katz

1998 Applications of Pubic Age Determination in a Forensic Ssetting. In Forensic Osteology: Advances in the Identification of Human Remains, edited by K. J. Reichs, pp. 204236. Charles C Thomas, Springfield, Illinois.

Texas Department of State Health Services, Vital Statistics Unit

1946 Certificate of Death, Maria Ramirez, April 24, 1946; issued May 8, 1946. Texas Department of State Health Services, Vital Statistics Unit, Austin.

1950 Certificate of Death, Salvador Camarena, January 17, 1950; issued October 17, 2011. Texas Department of State Health Services, Vital Statistics Unit, Austin. 
Texas Department of Transportation

2013 Section 10: Memorial Markers Within the Right of Way. In Use of Right of Way by Others Manual. Manual Notice: 20132 from F. Howard Holland, Director, Maintenance Division, Revised October 1, 2013. Electronic document, http://onlinemanuals.txdot.gov/txdotmanuals/use/ memorial_markers_within_the_right_of_ way.htm, accessed May 20, 2014.

2014a Highway Designation File, s.v. "Farm to Market Road No. 3078.” Electronic http:// www.txdot.gov/tpp/hwy/fm3000/fm3078. htm, accessed May 20, 2014.

2014b Highway Designation File, s.v. "Farm to Market Road No. 481." Electronic document, http://www.txdot.gov/tpp/hwy/fm/ fm0481.htm, accessed accessed May 20, 2014.

Texas Department of Transportation, Eagle Pass Maintenance Office

n.d. Transcription for Salvador Camarena Grave Plate, Handwritten on the Back of a Polacolor Instant Print. On file with the Texas Department of Transportation, Eagle Pass Maintenance Office.

Texas Department of Transportation, Environmental Affairs Division, Archeological Studies Branch

n.d. Transcription for Salvador Camarena grave plate. On file with the Texas Department of Transportation, Environmental Affairs Division, Archeological Studies Branch, Austin.

Texas State Highway Department

1961 General Highway Map of Maverick County. Texas State Highway Department, Austin, in cooperation with the U.S. Department of Commerce, Bureau of Public Roads, Washington, D.C.; original 1958, state highway revised to January 1, 1961. Electronic document, https://www.tsl.state. tx.us/arc/maps/images/map5231.jpg, accessed May 20, 2014.

Tise, M. L., M. K. Spradley, and B. E. Anderson

2012 Postcranial Sex Estimation of Individuals Considered Hispanic. Journal of Forensic Sciences. Online journal of the American Academy of Forensic Sciences, prior to print. Electronic document, http://www. ncbi.nlm.nih.gov/pubmed/23127214, accessed November 29, 2012.
U.S. Department of Commerce, Bureau of the Census

1920a Cook County, Illinois, manuscript population schedule. Heritage Quest Online, subscription database, accessed June 9, 2014.

1920b Erath County, Texas, manuscript population schedule. Heritage Quest Online, subscription database, accessed February 27, 2012.

1930 Galveston County, Texas, manuscript population schedule. Heritage Quest Online, subscription database, accessed February 27, 2012.

U.S. Department of the Interior, Geological Survey

1959 Indian Creek, Texas, Quadrangle. U.S. Geological Survey, Washington, D.C.

U.S. Immigration and Naturalization Service, U.S. Department of Justice

1924a Manifest card for Margarita Camarena. Statistical and Nonstatistical Manifest of Alien Arrivals at Brownsville, Texas, and Related Indexes, February 1905-June 1953, Record Group 85, Records of the U.S. Immigration and Naturalization Service, Microfilm Serial M1502, Microfilm Roll 20. National Archives and Records Administration, Washington, D.C.Ancestry. com, subscription database, accessed February 27, 2012.

1924b Manifest card for Jesus Camarena. Statistical and Nonstatistical Manifest of Alien Arrivals at Brownsville, Texas, and Related Indexes, February 1905-June 1953, Record Group 85, Records of the U.S. Immigration and Naturalization Service, Microfilm Serial M1502, Microfilm Roll 20. National Archives and Records Administration, Washington, D.C.Ancestry. com, subscription database, accessed February 27, 2012.

1928 Manifest card for Salvador Camarena. Statistical and Nonstatistical Manifest of Alien Arrivals at Brownsville, Texas, and Related Indexes, February 1905-June 1953, Record Group 85, Records of the U.S. Immigration and Naturalization Service, Microfilm Serial M1502, Microfilm Roll 23. National Archives and Records Administration, Washington, D.C. National Archives and Records Administration, Washington, D.C. Ancestry.com, subscription database, accessed February 27, 2012. 
1929a Manifest card for Margarita Camarena de Manriquez. Manifests of Statistical and Some Nonstatistical of Alien Arrivals at Laredo, Texas, May 1903-April 1955, Record Group 85, Records of the U.S. Immigration and Naturalization Service, Microfilm Serial A3437, Microfilm Roll 107. National Archives and Records Administration, Washington, D.C.Ancestry. com, subscription database, accessed February 27, 2012.

1929b Manifest card for Jose Maria Hernandez. Manifests of Statistical and Some Nonstatistical of Alien Arrivals at Laredo, Texas, May 1903-April 1955, Record Group 85, Records of the U.S. Immigration and Naturalization Service, Microfilm Serial A3437, Microfilm Roll 107. National Archives and Records Administration, Washington, D.C. Ancestry.com, subscription database, accessed February 27, 2012.

1941 Manifest card for Margarita Camarena de Manriquez. Manifests of Statistical and Some Nonstatistical of Alien Arrivals at Laredo, Texas, May 1903-April 1955, Record Group 85, Records of the U.S. Immigration and Naturalization Service, Microfilm Serial A3437, Microfilm Roll 114. National Archives and Records Administration, Washington, D.C.Ancestry. com, subscription database, accessed February 27, 2012.

1944 Manifest for card Maria Ramirez Viuda de Camarena. Manifests of Statistical and Some Nonstatistical of Alien Arrivals at Laredo, Texas, May 1903-April 1955, Record Group 85, Records of the U.S. Immigration and Naturalization Service, Microfilm Serial A3437, Microfilm Roll 112. National Archives and Records Administration, Washington, D.C.Ancestry. com, subscription database, accessed February 27, 2012.
1945 Manifest card for Maria de Jesus Camarena Ramirez. Permanent and Statistical Manifests of Alien Arrivals at Eagle Pass, Texas, June 1905-June 1953, Record Group 85, Records of the U.S. Immigration and Naturalization Service, Microfilm Serial M1755, Microfilm Roll 29. National Archives and Records Administration, Washington, D.C. Ancestry.com, subscription database, accessed February 27, 2012.

1951 Manifest card for Jesus CamarenaHerrera. Permanent and Statistical Manifests of Alien Arrivals at Eagle Pass, Texas, June 1905-June 1953, Record Group 85, Records of the U.S. Immigration and Naturalization Service, Microfilm Serial M1755, Microfilm Roll 30. National Archives and Records Administration, Washington, D.C. Electronic document, http://search.ancestry.com/iexec?htx $=\mathrm{V}$ iew $\& \mathrm{r}=$ an $\&$ dbid $=1082 \&$ iid $=$ TXM 1755 _30-0437\&fn=Jesus\&ln=Camarena-herr era\&st $=$ r\&ssrc $=\&$ pid $=1194488$, accessed February 27, 2012.

1970 Petitioner Jesus Herrera Camarena, also known as Jess Herrera Camarena. Index to Naturalizations of the U.S. District Court for the District of Hawaii, 1970-1976, Microfilm Serial M2074, Microfilm Roll 4. National Archives and Records Administration, Washington, D.C. Ancestry.com, subscription database, accessed February 27, 2012.

U.S. Selective Service System

1918 Registration for Salvador Camarena. World War I Draft Registration Cards, 19171918, Cook County, Illinois, Roll 1493589 , Draft Board 38. National Archives and Records Administration, Washington, D.C. Ancestry.com, subscription database, accessed June 9, 2014. 



\section{APPENDIX A: Timeline of Events and Key Documents}

Christopher W. Ringstaff and

Douglas K. Boyd 

This appendix contains a timeline of events and key documents pertaining to the historical research and archeological excavation of the grave of Salvador Camarena along FM 481 in Maverick County, Texas, and the subsequent relocation of the burial remains at a new location in La Marque, Texas. The original timeline was kept as a detailed record of events by the Archeological Studies Program, Environmental Affairs Division, Texas Department of Transportation (TxDOT), and it has been expanded to include all of the main events and key legal documents associated with the exhumation and reinterment of the burial.

The timeline starts in August 2010 with TxDOT's initial inquiry regarding a roadside marker inside the FM 481 right of way. It ends in March 2013, when TxDOT issued a work authorization to have Prewitt and Associates assist in writing and producing this final report on the Camarena burial investigations. It encompasses all the major events associated with this project. All of the efforts described herein were completed as part of CSJ No. 1590-03-965 for TxDOT's Laredo District.

Throughout the process, TxDOT personnel were careful to follow all of the legal requirements for exhuming and relocating human remains. All of the steps described herein are in strict compliance with the cemetery provisions in the Texas Health and Safety Code, specifically the regulations in Chapters 711 and 712, and in Chapter 22 of the Texas Administrative Code (13 TAC §22). Copies of the following legal documents are included as attachments to this appendix:

Attachment A1:

Notice of Existence of Cemetery Form, filed February 7, 2011, and processed

February 14, 2011.

Attachment A2:

Coordination Letter, from TxDOT

(Christopher Ringstaff) to the Texas

Historical Commission, Archeology

Division (James Bruseth), February 17, 2011.

Attachment A3:

Texas Antiquities Permit No. 6043, issued by the Texas Historical Commission, Archeology Division, to Christopher
Ringstaff (TxDOT staff archeologist), September 15, 2011.

Attachment A4:

Next-of-Kin Consent Form, signed by Jesus Herrera Camarena (Salvador Camarena's son), May 28, 2012.

Attachment A5:

Court Order for Removal of the Cemetery

Dedication, Cause No. 12-08-27705-

MCVAJA, signed by the Maverick County

District Court Judge (365 ${ }^{\text {th }}$ Judicial

District), August 22, 2012.

Attachment A6:

Transmittal Letter and Disinterment

Permit issued by the State Department of Health Services, Office of Vital Statistics, September 21, 2012.

\section{TIMELINE OF EVENTS}

\section{August 18, 2010}

TxDOT archeologist Christopher Ringstaff was contacted by TxDOT Laredo District about a purported grave in the stateowned right of way of FM 481, Maverick County, Texas. The site consisted of a welded iron fence and cross that fell inside the designated safety zone of a public road right of way. An increase in the Average Daily Traffic had required an expansion of the "safety zone" along FM 481. When the width of the safety zone was increased, it encompassed the potential gravesite. The heavy iron structure within the public highway safety zone was considered a hazard that needed to be removed if possible.

Ringstaff informed the district that the safety issue was a valid one, and he suggested that TxDOT proceed with the legal paperwork and necessary steps to have the hazard removed. He recommended that the location be tested, and if the marker was found to be associated with a human grave, that it be removed and relocated. He noted that the excavation of a human grave would require coordination with the Texas Historical Commission, a disinterment permit from the Texas Department of State Health Services, and 
a court order from the Maverick County District Court Judge.

\section{November 10, 2010}

In response to TxDOT Laredo District's request for information on the roadside marker along FM 481, John Sullivan of the Maverick County Historical Commission informed TxDOT that the roadside marker in question might be a grave. He provided a contact name of a former ranchhand who claimed that the grave dated to the 1970s. The contact, Jesus Sanchez, gave TxDOT the name and phone number of Diana Perez (now Diana Escareño), who works with the Eagle Pass Police Department.

\section{November 30, 2010}

TxDOT archeologist Ringstaff spoke with Escareño, who identified the marker in question as a fatality marker. Escareño said that she is the sister of Belinda Perez-Martin, who was killed along with her husband, Frank Martin, at that location in a 1983 auto accident. Escareño said that they are not buried at that location but that the marker and welded fence is a roadside memorial. Ringstaff explained the safety issue concerning the welded pipe fence raised by TxDOT District Engineers and asked if it would be a problem to remove the memorial marker and perhaps offset the cross out of the designated safety zone. Escareño had no objection.

\section{December 2010}

After contacting local informants, Ringstaff conducted a Geographic Information System (GIS) analysis of the area, which led to the discovery of a grave marker symbol at this location on the 1974 Trosado Tank, Texas, USGS topographic quadrangle map. The designation "Graves" appeared next to the symbol, suggesting that more than one grave might be present. Since this 1974 map predated by nearly 10 years Escareño's stated 1983 auto accident date, this new evidence necessitated additional investigations by TxDOT archeologists.

\section{January 17, 2011}

Ringstaff conducted a survey within the
FM 481 right of way to determine the presence or absence of a human grave(s). The iron fence and marker were moved, and a Gradall was used to carefully scrape the area. When human bones and part of a shoe were encountered, the mechanical digging was halted. The investigation suggested the presence of an articulated human skeleton. This survey was conducted under authority of the Memorandum of Understanding between TxDOT and the Texas Historical Commission and therefore did not require an antiquities permit.

\section{February 2, 2011}

Ringstaff submitted an interim report titled Abandoned Cemetery Investigation of FM 481, Maverick County, Texas. This report included the following findings and recommendations:

1. In situ human remains were found, confirming that the location was a gravesite. All excavations were halted.

2. Loose fill was placed on top of the human remains, and a section of the iron fence was placed over the grave location. The area was then mechanically backfilled to the original ground level.

3. The gravesite meets the definition of an "Abandoned Cemetery" and a "Marked Grave" in the Texas Administrative Code, as defined in 13 TAC §22.1(1) and 13 TAC $\S 22.1(8)$.

4. A "Notice of Existence of Cemetery Form" will be filed with the Maverick County Clerk, as required by 13 TAC $\$ 22.4$ (a) of the Texas Administrative Code.

5. TxDOT recommends publication of public notices in local newspapers and additional research "to ascertain, if possible, the identity of the individual(s) within the abandoned cemetery."

6. TxDOT stated that all work relating to the burial relocation would be conducted in strict adherence to the cemetery provisions in the Health and Safety Code (Chapters 711 and 712) and the Texas Administrative Code (13 TAC §22).

\section{February 7-14, 2011 (Attachment A.1)}

As required in the Texas Administrative Code, Part 2, Chapter 22 (13 TAC 
$\S 22.4(\mathrm{a})$ ), a "Notice of Existence of Cemetery" form was signed, notarized, and filed with the Maverick County Clerk on February 7, 2011. At this time, the identity of the person or persons buried in the grave was not known. The Notice of Existence of Cemetery form was processed by the Maverick County Clerk on February 14, 2011, and filed as Document No. 164157 in Book 1276, Pages 315-319.

\section{February 17, 2011 (Attachment A.2)}

TxDOT sent a letter describing the abandoned gravesite to the Texas Historical Commission (Ringstaff to Dr. James E. Bruseth, Division of Archeology). The letter stated: that the location is an abandoned cemetery under the Health and Safety Code; that TxDOT intends to publish public notices to try and locate next of kin and then proceed with exhuming and relocating the grave(s); and that TxDOT will apply for a Texas Antiquities Permit and conduct the burial removal and relocation in strict adherence with 13 TAC $\S 22$ of the Texas Administrative Code and Chapter 711 of the Health and Safety Code. The Texas Historical Commission concurred with TxDOT's findings and recommendations on the same day (signed by Mark Denton).

\section{March 25, 2011}

A public notice request for information about the gravesite on FM 481 was submitted for publication in the Eagle Pass News Gram. The notice, printed in English and Spanish, was published in three consecutive Sunday editions: on March 27, April 3, and April 10, 2011.

\section{March 29, 2011}

Letters requesting information about the gravesite on FM 481, in English and Spanish, were mailed to six local churches:

- First Baptist Church of Eagle Pass

- River of Life Church

- First United Methodist Church

- Our Lady of Refuge Church

- Sacred Heart Catholic Church

- St. Joseph's Catholic Church

\section{April 2011}

Two responses were received in response to the information requests. On April 4, United Methodist Church member Peggy Stock called and said that she believed the location was a fatality marker. On April 11, Eagle Pass resident Mike Garcia responded by phone to The News Gram public notice, indicating that he believed the location to be a fatality marker.

\section{April 28, 2011}

Information request letters were sent to Maverick County property owners that owned land near the gravesite along FM 481. These letters were mailed to:

- Groff Land Enterprise, LP

- Roswell Family Ranch Limited Partnership

- Jaime and Teresa Kypuros

- Ranch Rico, LLC

\section{May 2011}

Responding by phone to the property owner information request, Charles Roswell, whose family owns land immediately adjacent to the gravesite, contacted Ringstaff on May 2. Roswell stated that the gravesite was formerly located on his ranch before the right of way was expanded in the 1980s and that the grave was that of a migrant worker. Roswell said that workers with the Coastal Oil and Gas Company, who had a village known as the "gas camp" approximately three miles south of the gravesite location, welded the cross from drilling pipe and buried the individual. He stated that Texas Department of Highways and Public Transportation installed the iron pipe fence around the grave, probably in or before the 1980s. This story is generally confirmed by Mike Graham, the current environmental coordinator for TxDOT's Laredo District. In an email dated May 1, 2014, Graham stated that several people in the district had heard that the adjacent landowner and local oil-field crews offered to put a marker on the grave, and that they constructed and installed the pipe fence and cross. Graham believes that this occurred when the county road was upgraded to a ranch- 
to-market road in the 1970s. This was probably handled on an informal basis, and Graham said that no State Highway Department records have been found to confirm this.

\section{May 9, 2011}

Later in May, two other landowners, Larry Hall and Teresa Kypuros, responded to the property owner information request. They both indicated that they believed the location to be a fatality marker.

\section{August 22, 2011}

Since the Roswell family's Las Cruces Ranch was named after the prominent cross monument, Ringstaff proposed that the family consider dedicating a small roadside plot adjacent to the current location to relocate the grave. The proposal included a provision that TxDOT would pay the costs of the grave relocation, including construction of the enclosure and placement of a permanent marker at the site. Landowner Charles Roswell emailed a response on behalf of the Roswell Family Ranch Limited Partnership. He wrote that despite their personal connection to the gravesite that was originally on their land, the Roswell family was not interested in having the grave moved out of the stateowned right of way onto their property.

\section{September 15, 2011 (Attachment A.3)}

TxDOT submitted an application for an antiquities permit to the Texas Historical Commission, and the commission issued Antiquities Permit No. 6043 on the same day. The permit allowed for the archeological excavation, documentation, and reporting of the historic grave, followed by the reinterment of the burial remains.

\section{September 29, 2011}

Old photographs of the gravesite, reportedly from the 1980 s, were found in the files of TxDOT's Eagle Pass maintenance shop and provided to Ringstaff. One of the images is of a rectangular metal plaque that had once been attached to the iron cross. Written in Spanish, it read: "Salvador Camarena, dedican este recuerdo sus hermanas, Maria y Margarita, y su esposa e hijos, Eagle Pass, Texas." This translates to "Salvador Camarena, dedicated as a remembrance by his sisters, Maria and Margarita, and his wife and kids, Eagle Pass, Texas." This photograph provided conclusive evidence identifying the gravesite as that of Salvador Camarena.

\section{October 17, 2011}

Historian Summer Chandler (TxDOT's Environmental Affairs Division) located a death certificate for Salvador Camarena. The document indicated that his body was found on January 17, 1950, and was buried nearby the same day. Chandler also located 1930 Mexican census data for Salvador Camarena, his mother, and one of his sisters, along with 1930 United States census data for one of his sisters who lived in Texas. All of the evidence confirmed that Camarena was a Mexican citizen who was born about 1897.

\section{October 25, 2011}

In an attempt to find family members, another public notice was submitted to the Eagle Pass newspaper (The News Gram) and The Galveston County Daily News. The notices were published in three issues of each newspaper, appearing on November 6, 13, and 20, 2011.

\section{January 25, 2012}

TxDOT issued Work Authorization No. 57108SA001 to Prewitt and Associates, Inc. (PAI) to provide a historian to assist with the archival research and attempt to find the family of Salvador Camarena. The work authorization also required PAI to provide a qualified physical anthropologist to conduct an analysis of the human skeletal remains once the grave was excavated. PAI historian Amy Dase conducted the archival research and search for relatives. Dr. M. Katherine Spradley, associate professor in the Department of Anthropology at Texas State University in San Marcos, agreed to serve as the forensic anthropologist.

\section{February 2012}

PAI historian Amy Dase conducted genealogical research and located several of Salvador Camarena's relatives. One of the identified relatives was Jesus "Jess" Herrera Camarena, who lives in Redding, 
California. Dase talked with Jesus and confirmed that he is the son of Salvador Camarena.

\section{March 6, 2012}

In communication with Dase, Jesus Herrera Camarena requested that his father's remains be reburied at La Marque Cemetery in Galveston County where other family members are located. This information was passed on to TxDOT.

\section{April 10, 2012}

PAI submitted to TxDOT a report on its preliminary research. Written by Amy E. Dase, the report is titled "Search for Relatives of Salvador Camarena (18971950), Vicinity of Eagle Pass, Maverick County, Texas." This document was a deliverable for Task 1 of Work Authorization No. 57108SA001. ${ }^{15}$

\section{May 28, 2012 (Attachment A.4)}

Jesus Herrera Camarena (Salvador Camarena's son) signed a next-of-kin consent form, authorizing the exhumation of his father's grave in Maverick County and reinterment of the burial remains at the La Marque Cemetery in Galveston County, Texas.

\section{June 14, 2012}

A cemetery plot for the reburial of Salvador Camarena's remains was reserved at the La Marque Cemetery in La Marque, Texas.

\section{June 21, 2012}

Philip Arnold (assistant attorney general with the Transportation Division of the Attorney General of Texas) was contacted to assist TxDOT in preparing the order for removal of the cemetery dedication by the Maverick County District Court Judge.

\section{August 22, 2012 (Attachment A.5)}

The order for removal of the cemetery dedication was signed by the Maverick County District Court Judge (365th Judicial District). This document is Cause No. 12-08-27705-MCVAJA. (The cause number is handwritten in two places, and the latter portion could be MCVAJA or MCUAJA.)

\footnotetext{
15 All of the findings from this preliminary report are incorporated into Chapter 3 of the current report.
}

September 21, 2012 (Attachment A.6)

TxDOT (Ringstaff) completed an Application for Disinterment Form and submitted it to the Department of State Health Services (Office of Vital Statistics) in Austin, Texas, on September 21, 2012. The Texas DSHS issued the disinterment permit for the exhumation of the Camarena burial on the same day.

\section{October 5, 2012}

TxDOT issued Supplemental No. 1 for Work Authorization No. 57108SA001. This change required PAI to find a physical anthropologist to assist the state with the field excavation of the Camarena burial. Physical anthropologist Dr. Catrina Banks Whitley agreed to act as a consultant for PAI and assist TxDOT with the burial excavation.

\section{October 10, 2012}

TxDOT's Right of Way Division completed the purchase of the reburial plot at La Marque Cemetery for the reinterment of Salvador Camarena's burial remains.

\section{October 10-11, 2012}

TxDOT archeologist Ringstaff and Dr. Catrina Banks Whitley (consultant for PAI) traveled to Maverick County and conducted the archeological excavation and disinterment of the Salvador Camarena burial. Whitley directed the excavation and removal. Mike Graham, environmental coordinator for TxDOT's Laredo District, assisted the archeologists in the removal and packaging of the remains for transport.

\section{October 12, 2012}

Whitley transported the remains to Texas State University in San Marcos and delivered them to Dr. Katherine Spradley with the Department of Anthropology and Forensic Anthropology Center at Texas State University for analysis. The personal items recovered from the grave were taken to TxDOT's Archeological Studies Program office for analysis.

\section{October 12-23, 2012}

Spradley conducted the osteological analysis of the skeletal remains. After analysis, 
the remains were placed into a newly constructed wooden reburial container.

\section{October 24, 2012}

Ringstaff drove from TxDOT to Texas State University's Department of Anthropology to pick up the skeletal remains. He placed them into a specially constructed reburial box burial along with the personal items from the Camarena burial. He then drove to La Marque, Texas, where he delivered the burial remains to the James Crowder Funeral Home.

\section{October 26, 2012}

Salvador Camarena's remains were reinterred at La Marque Cemetery in Galveston County, Texas. The James Crowder Funeral Home (401 Texas Avenue, La Marque, Texas, 77568) reinterred the remains, and a new grave marker was installed. The reburial plot (Space 9, Lot 133, Southeast Quad of the cemetery) is near the grave of Maria Camarena Pena, who was Salvador Camarena's sister. According to online information from Find A Grave, Inc. (www.findagrave.com), two of Salvador Camarena sisters are buried in La Marque Cemetery. The headstone photographs reveal that Maria C. Pena lived from December 27, 1909, to January 17, 1999, and Margarita Camarena de Manriquez lived from June 10, 1898, to September 30, 1982. Lilia Manriquez Flores, a niece of Salvador Camarena who lives in Texas City, attended the reinterment.

\section{October 26-November 6, 2012}

Jesus Herrera Camarena, Salvador Camarena's son, visited his father's gravesite during a trip to visit relatives in La Marque. This occurred sometime between the October 26 reinterment and November 6, 2012. On November 6, 2012, he left a voice message with Sharon Dornheim (TxDOT-ENV in Austin) expressing his appreciation for all of the efforts regarding the treatment of his father. He also expressed his gratitude for the professionalism and dignity that was shown for his father.

\section{December 6, 2012}

Ringstaff submitted an electronic site form to the Texas Archeological Research Laboratory, University of Texas at Austin. The original Camarena gravesite was designated as site 41MV372 in the state's archeological site numbering system.

\section{March 13, 2013}

TxDOT issued Work Authorization No. 57309SA003 to PAI to assist TxDOT with completing the draft and final reports for the historical and bioarcheological investigations of Salvador Camarena's gravesite. 


\section{Attachment A1:}

Notice of Existence of Cemetery

Form

Filed with the Maverick County

Clerk's Office,

February 7, 2011, and processed

February 14, 2011 


\section{Da: 164157 \\ NOTICE OF EXISTENCE OF CEMETERY}

THE STATE OF TEXAS

PRESENTS:

COUNTY OF Maverick

THAT the undersigned, acting pursuant to the provisions of Section 711.011 of the Texas Health and Safety Code, files this notice of the discovery of an unknown or abandoned cemetery. available):

The Cemetery is located (describe the location, including GPS information, if

The grave is located on the north side of FM 481 approximately 8.47 miles (13.63 km) northeast of the intersection of FM 481 and US 57. The grave is located approximately 12 feet south of a barbed-wire fence in a grassy area left un-mown by TxDOT and Border Patrol.

(Attachment 1, grave location map)

The Cemetery is evidenced by (describe features such as markers with inscriptions, graves marked only by stone, archaeological evidence resulting from inadvertent excavations, fencing, commonly used grave plantings (iris, crepe myrtle), or other evidence):

No markers are present at this time. Prior to January 17, 2011 a welded 4-inch steel pipe fence measuring approximately 12 feet by 9 feet was located at the site with a 6foot tall welded metal cross with no name on the fence or cross. On January 17, 2011, TxDOTarcheologists removed the fence and cross in an effort to verify the presence or absence of a grave at that location after receiving conflicting information about the marker. The investigation revealed the presence of a least one grave (see attached statement below).

On November $10^{\text {th }}$ 2010, the Texas Department of Transportation (TxDOT) Laredo District received e-mail correspondence from Mr. John Sullivan of the County Historic Commission regarding a query relating to a roadside marker on FM481(Attachment 2, photo of marker). Mr. Sullivan informed TXDOT that the roadside marker in question may be a grave and provided a contact name of a former ranch hand who claimed the grave dated to the 1970's. The contact, Mr. Jesus Sanchez, gave TxDOT the name and phone number of the family of the deceased, Ms. Diana Perez (now Diana Escareño) of the Eagle Pass Police Department.

On November $30^{\text {th }} 2010$, Archeologists with TxDOT spoke with Ms Diana Escarefio who identified the purported grave marker in question as a fatality marker. Ms Escarefio stated that she is the sister of the deceased Belinda Perez-Martin and that Ms. Perez-Martin and her husband Frank Martin were killed at that location in 1983

$$
\text { Book } 1276 \text { Page } \mathbf{3 1 5}
$$


in a rollover accident. Ms Escarefio said they are not buried at that location and that the marker and welded fence is a monument. TXDOT archeologists explained the safety issue concerning the welded pipe fence raised by TxDOT District Engineers and asked if it would be a problem to remove the monument and perhaps offset the cross out of the designated safety zone. She had no objection.

A subsequent Geographic Information System (GIS) analysis of the area in question revealed the location exhlbited a grave marker symbol on the 1974 United States Geologic Survey Topographic Quadrangle, a date that predated Ms. Escareito's account by nearly ten years. The contradictory data necessitated an investigation of the location by TxDOT Archeologists. The investigation verified the presence of a least one grave with the possiblitity of others.

The legal description for the land occupied by the Cemetery is (provide survey and abstract numbers and a description, attach as an Exhibit to Notice if necessary):

The Cemetery is Located within Texas Department of Transportation Right-of-Way of FM 481 approximately 8.47 miles $(13.63 \mathrm{~km})$ northeast of the intersection of FM 481 and US 5:

This Notice signed and executed on the 7th day of February, 2011.

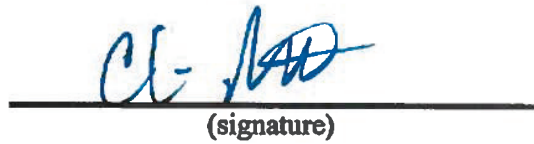

Christopher Ringstaff

(printed name)

118 E. Riverside Dr., Austin, Texas 78704

\section{THE STATE OF TEXAS}

COUNTY OF Travis

This instrument was acknowledged before me on the 7th day of February , 2011,

by

Julie Pollard

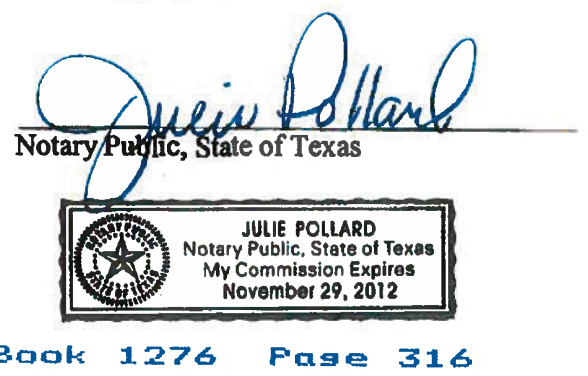


Relocation of the Salvador Camarena Burial

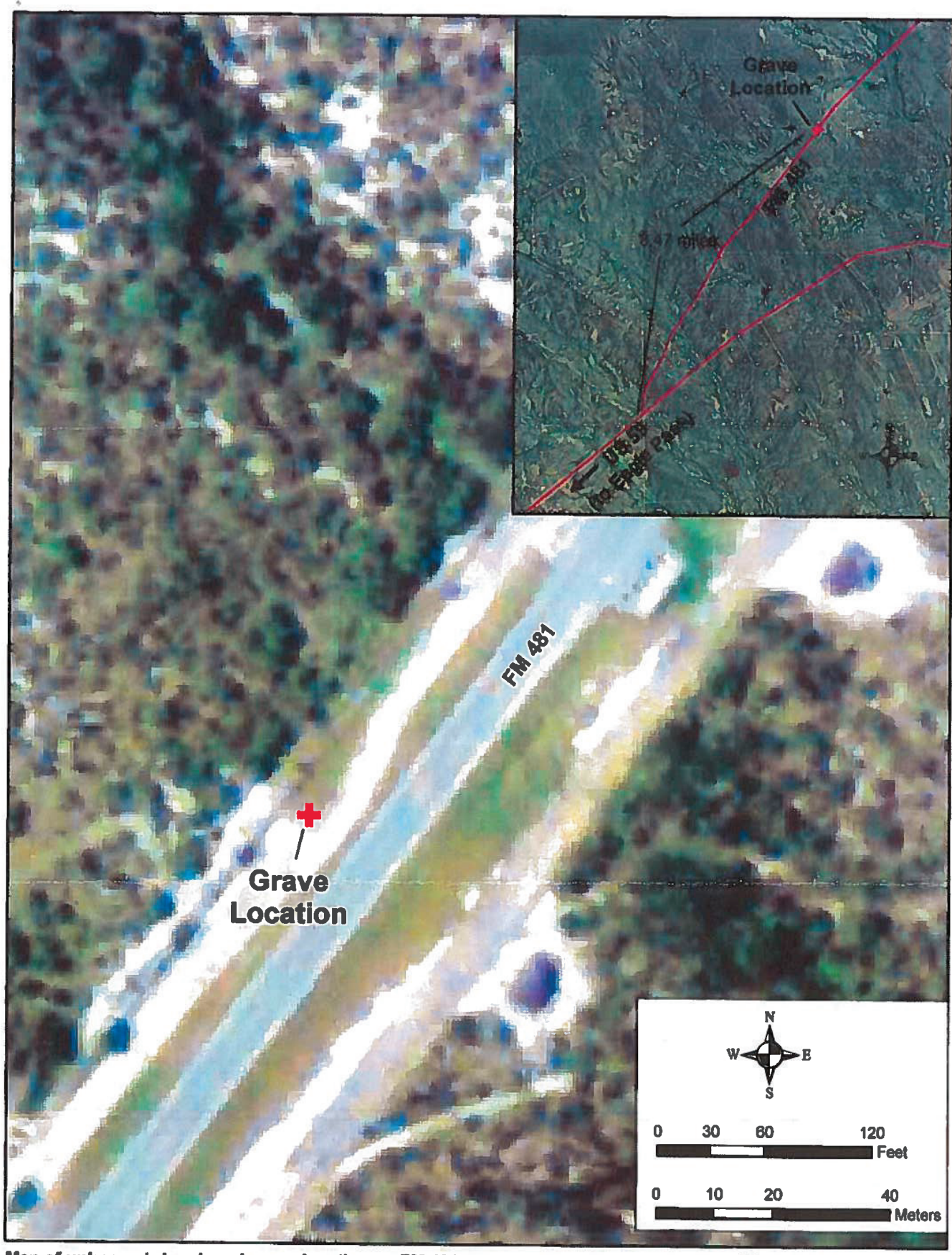

Map of unknowm/ abandoned grave location on FM 481 approx 8.4Zmiles north gf YS 69, Maverick Counny, Toxas. 


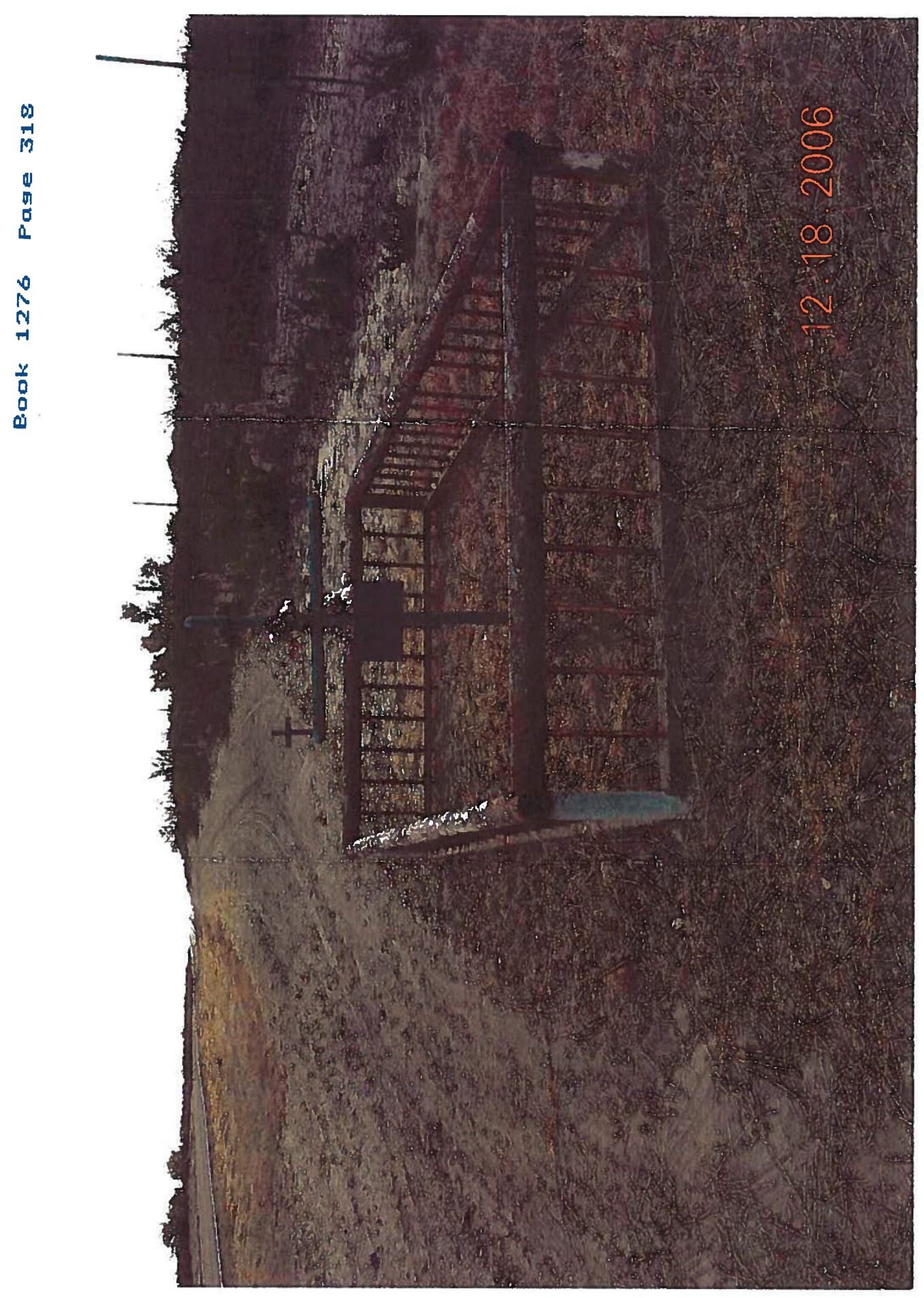




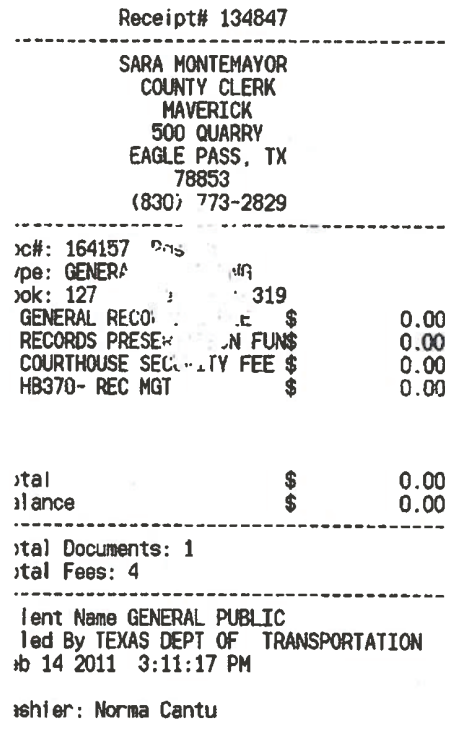

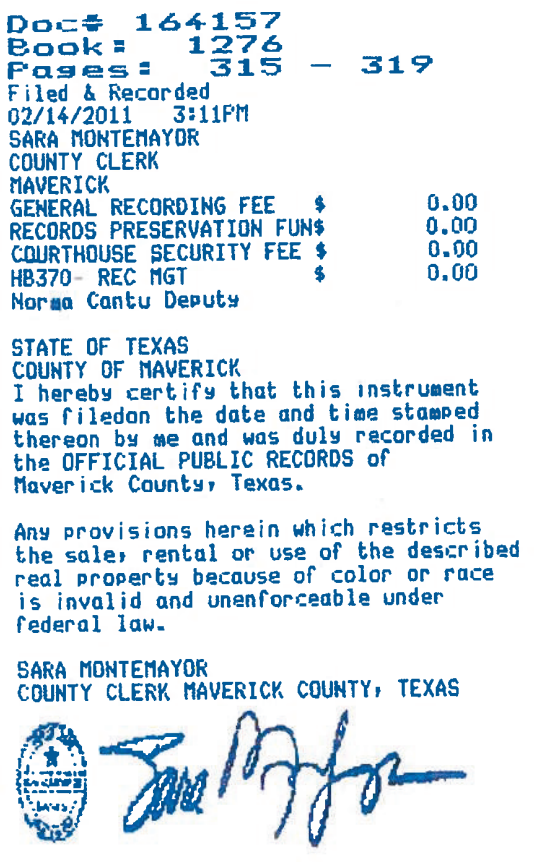

Dook 1276 Fag= 319 


\section{Attachment A2:}

Coordination Letter

From the Texas Department of

Transportation (Christopher

Ringstaff) to the Texas Historical

Commission, Archeology Division

(James Bruseth), February 17,

2011

Note: Only the first page of the

seven-page interim report of

February 1, 2011, is included. 


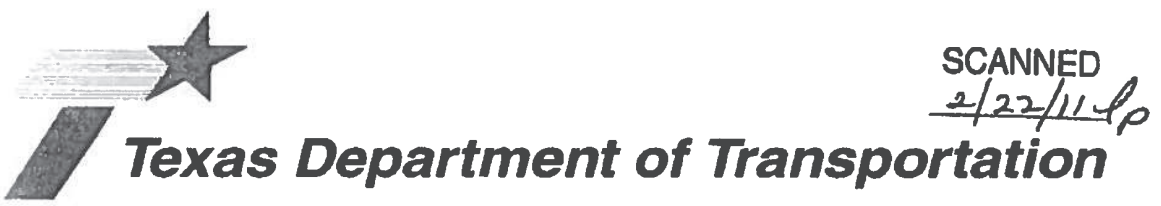

DEWITT C, GREER STATE HIGHWAY BLDG. • 125 E. 11TH STREET • AUSTIN, TEXAS 78701-2483 • (512) $463-8585$

February 17, 2011

Initiation of $13^{\prime} \mathrm{TAC}^{2} 2$ and Hcalth and Safety Code Chapters 711 and 712 Consultation: Transmittal of TxDOT Interim Report.

Abundoned Cemereng Investigution on FM 481, Muverick County. Texus.

CSJ: $1590-03-965$

James E. Bruseth, Ph.D.

Division of Archeology, Texas Historical Commission

P.O. Box 12276

Austin, Texas 78711

Dear Dr. Bruseth:

Enclosed for your review is an interim report of the above refernced investigation conducted under the Memorandum of Understanding (MOU) between the Texas Department of Transportation (TxDOT) and Texas Historical Commission (THC). As required by the MOU with your agency, we are initiating consultation with your office by the submission of this interim report for your review and processing.

The project consists of Gradall scraping and verification of a purported grave located within FM 481 ROW approximately 8.47 miles $(13.63 \mathrm{~km})$ northeast of the intersection of FM 481 and US 57 in Maverick County, Texas. A survcy within the FM 481 ROW was performed by a TxDOT archeologist on January 17, 2011 to determine the presence or absence of a grave(s). Prior to fieldwork, e-mail correspondence and interviews with the County Historical Commission and Eagle Pass residents supplied contradictory information on whether the marker and enclosure were associated with a grave or an claborate fatality marker thus necessitating verification. Gradall scraping revealed the presence of a grave at which point excavations where immediately halted. The grave meets the definition of Marked Grave per 13TAC22.1(8) and Abandoned Cemetery per 13TAC22.1(1). As such, a Notice of Existence of Cemetery was filed with the Maverick County Clerk per 13TAC22.4(a).

\section{TxDOT seeks THC concurrence that:}

1. The abandoned cemctery location within the FU 481 ROW is in violation of Health and Salfety (ode Chapter 711

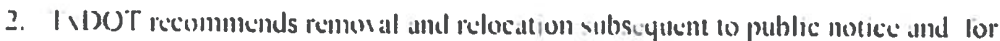
notilication of next of kin. If no relatio es can be identified to pros ide permissions. IIDU [ will obtain necessar! permissions from the District ('oun in compliance wilh Health and Satety code (happer-11. 
Iniliation of 13 TAC22 and I icalth and Salcty Code Chapters 711 and 712 Consultation Transmittal of TXDOT Interim Report,

Abandoned Cemetery Invertigation on Fi.4 481 , Waverick Count: Texas.

3. 3. A Texas Antiquities Permit application will be submitted for the removal of the remains. All work relating to removal and relocation will be conducted in strict adherence to 13TAC 22 and Health and Safety Code Chapter 711.

Thank you for your consideration of this matter. If you have any questions regarding the interim report, please contact me at 416-2647. Thank you for your consideration in this matter.

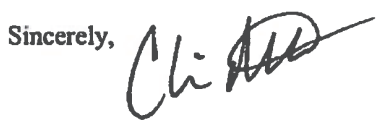

Christopher Ringstaff, Archeological Studies Program

Environmental Affairs Division

Cc w/attachment: Mike Graham TxDOT Laredo District Environmental Coordinator; Mike Graham, TxDOT Laredo District Environmental Coordinator; Sonya Hernandez, ENV-PD; Christopher Ringstaff ENV-Arch TxDOT; ENV Arch Project File

cc w/o attachments: ETS Scan

Concurrence By:
for: Mark Wolfe, Executive Director and SHPO
Texas Historical Commission




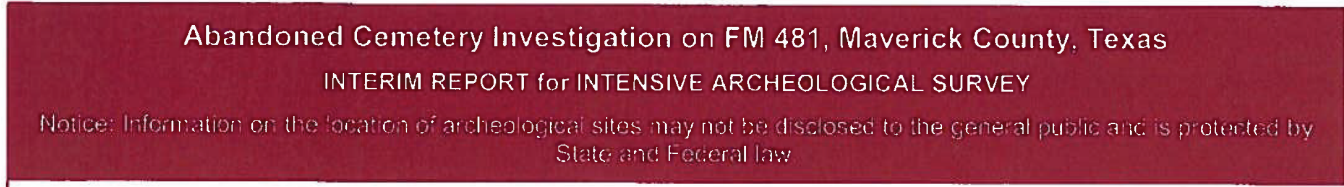

Date: 02/01/2011

Highway: FM 481 Creek.

Countles: Maverick

USGS Quad(s): Trosado Tank

CSJ: 1590-03-965

Report Written by: Christopher Ringstaff
Date(s) of Survey: 01/17/2011

Jurisdiction: Federal $\square$ State 8

District: Laredo

Texas Antiquities Permit Number: THC/TxDOT MOU

Project Type: Cemetery in TxDOT ROW.

Total Project Acreage: < 0.1 acres

Now ROW Acreage: N/A

Easement Acreage: N/A

Area of Survey: $<0.1$ acres

\section{Prolect Descriptlon and Impacts}

The project consisted of Gradall scaping and verfication of a purported grave within FM 481 ROW. The grave is located approximately 8.47 miles $(13.63 \mathrm{~km}$ ) northeast of the intersection of FM 481 and US 57 in Maverick County, Texas (Figure 1). The project was initiated when a marker and associated welded metal enclosure within the safety zone of the FM 481 ROW was brought to the attention of Texas Department of Transportation (TxDOT) archeologists (Figure 2). At this time, no road construction or road improvement activities are planned in this area.

Project Area Ownership: The project area is located within TxDOT ROW.

\section{Prolect Setting}

Topography: The project area is located level to gently rolling on a strath terrace of the San Filipe Creek.

Geology: The project area is located on Pleistocene Quaternary Terrace Deposits.

Solls: Soils in the project area consist of Reynosa Silty Clay Loam as indicated by the United States Department of Agriculture Soil Survey of Val Verde County, Texas (SSURGO).

Land Use: Transportation (TxDOT ROW).

Vegetation: The area is cleared although short grasses are found in the ROW where Border Security avoids the enclosure whlle dragging tires to smooth the sandy solls for footprint monitoring.

Estimated Ground Surface Visibility: Very Good approx $90 \%$

Previous Investigations and Known Archeologlcal Sites: A review of the Texas Historical Commission's online Texas Archeological Sites Atlas (ATLAS) concluded no archeological sites have been previously recorded within or adjacent to the project area nor has any prior archeological survey been conducted within 1 $\mathrm{km}$ of the project area. 


\section{Attachment A3:}

Texas Antiquities Permit No. 6043

Issued by the Texas Historical

Commission, Archeology Division, to TxDOT (Christopher Ringstaff), September 15, 2011 


\section{TEXAS HISTORICAL COMMISSION}

real places telling real stories

September 20, 2011

Christopher Ringstaff

Texas Department of Transportation

125 East $11^{\text {th }}$ Street

Austin, TX 78748

Re: Project review under the Antiquities Code of Texas

FM 481 Abandoned Cemetery Relocation, Maverick County, Texas

Texas Antiquities Permit Application \#6043

Dear Colleague:

Thank you for your Antiquities Permit Application for the above referenced project. This letter presents the final copy of the permit application from the Executive Director of the Texas Historical Commission, the state agency responsible for administering the Antiquities Code of Texas.

Please keep this copy for your records. The Antiquities Permit investigations now requires the production and submittal of one printed copy of the final report, a completed abstract form submitted electronically, two copies of the final report on a tagged PDF CD (one with site location information \& one without), and verification that any artifacts recovered and records produced during the investigations are curated at the repository listed in the permit.

If you have any questions concerning this permit or if we can be of further assistance, please contact Lillie Thompson at 512/463-1858. The reviewer for this project is Mark Denton, 512/463-6096.

\section{Sincerely,}

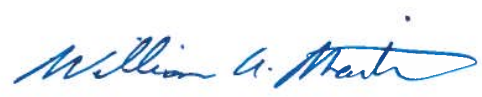

for

Mark Wolfe

Executive Director

$\mathrm{MW} / \mathrm{lft}$

Enclosure

Cc: Jason Barrett, TxDOT
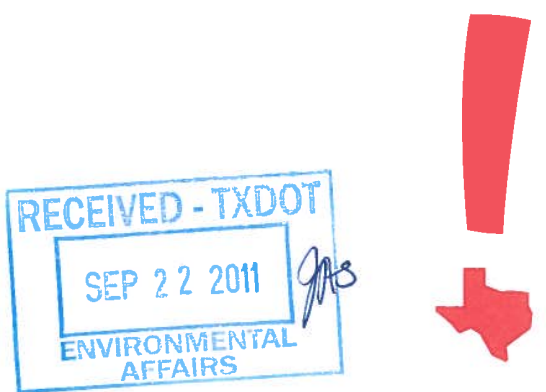

RICK PERRY, GOVERNOR • JON T. HANSEN, CHAIRMAN • MARK WOLFE, EXECUTIVE DIRECTOR

P.O. BOX $12276 \bullet$ AUSTIN, TEXAS • $78711-2276 \bullet P$ 512.463.6100 • F 512.475.4872 • TDD 1.800.735.2989 • www.thc.state.tx.us 


\section{State of Texas \\ TEXAS ANTIQUITIES COMMITTEE ARCHEOLOGY PERMIT \# 6043}

This permit is issued by the Texas Historical Commission, hereafter referred to as the Commission, represented herein by and through its duly authorized and empowered representatives. The

Commission, under authority of the Texas Natural Resources Code, Title 9, Chapter 191, and subject to the conditions hereinafter set forth, grants this permit for:

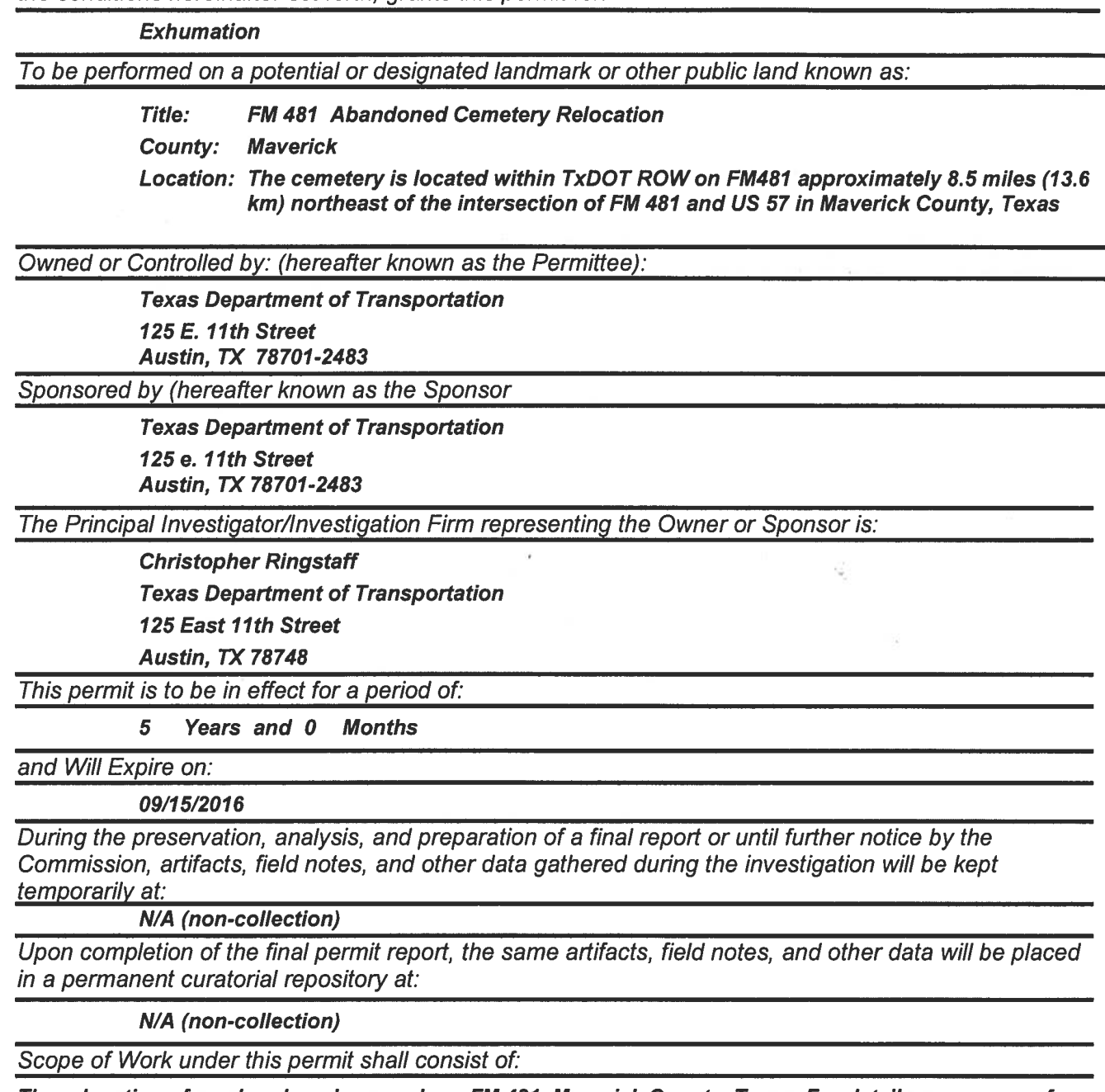

The relocation of an abandoned grave along FM 481, Maverick County, Texas. For details, see scope of work submitted with permit application. 
This permit is granted on the following terms and conditions:

1) This project must be carried out in such a manner that the maximum amount of historic, scientific, archeological, and educational information will be recovered and preserved and must include the scientific, techniques for recovery, recording, preservation and analysis commonly used in archeological investigations. All survey level investigations must follow the state survey standards and the THC survey requirements established with the projects sponsor(s).

2) The Principal Investigator/Investigation Firm, serving for the Owner/Permittee and/or the Project Sponsor, is responsible for insuring that specimens, samples, artifacts, materials and records that are collected as a result of this permit are appropriately cleaned, and cataloged for curation. These tasks will be accomplished at no charge to the Commission, and all specimens, artifacts, materials, samples, and original field notes, maps, drawings, and photographs resulting from the investigations remain the property of the State of Texas, or its political subdivision, and must be curated at a certified repository. Verification of curation by the repository is also required, and duplicate copies of any requested records shall be fumished to the Commission before any permit will be considered complete.

3) The Principal Investigator/Investigation Firm serving for the Owner/Permittee, and/or the Project Sponsor is responsible for the publication of results of the investigations in a thorough technical report containing relevant descriptions, maps, documents, drawings, and photographs. A draft copy of the report must be submitted to the Commission for review and approval. Any changes to the draft report requested by the Commission must be made or addressed in the report, or under separate written response to the Commission. Once a draft has been approved by the Commission, one (1) printed, unbound copy of the final report containing at least one map with the plotted location of any and all sites recorded and two copies of the report in tagged PDF format on an archival quality CD or DVD shall be fumished to the commission. One copy must include the plotted location of any and all sites recorded and the other should not include the site location data. A paper copy and an electronic copy of the completed Abstracts in Texas Contract Archeology Summary Form must also be submitted with the final report to the Commission. (Printed copies of forms are available from the Commission or also online at www.thc.state.tx.us.)

4) If the Owner/Pemittee, Project Sponsor or Principal Investigator/Investigation Firm fails to comply with any of the Commission's Rules of Practice and Procedure or with any of the specific terms of this permit, or fails to properly conduct or complete this project within the allotted time, the permit will fall into default status. A notification of Default status shall be sent to the Principal Investigator/Investigation Firm, and the Principal Investigator will not be eligible to be issued any new permits until such time that the conditions of this permit are complete or, if applicable, extended.

5) The Owner/Permittee, Project Sponsor, and Principal Investigator/Investigation Firm, in the conduct of the activities hereby authorizes, must comply with all laws, ordinances and regulations of the State of Texas and of its political subdivisions including, but not limited to, the Antiquities Code of Texas; they must conduct the investigation in such a manner as to afford protection to the rights of any and all lessees or easement holders or other persons having an interest in the property and they must retum the property to its original condition insofar as possible, to leave it in a state which will not create hazard to life nor contribute to the deterioration of the site or adjacent lands by natural forces.

6) Any duly authorized and empowered representative of the Commission may, at any time, visit the site to inspect the fieldwork as well as the field records, materials, and specimens being recovered.

7) For reasons of site security associated with historical resources, the Project Sponsor (if not the Owner/Permittee), Principal Investigator, Owner, and Investigation Firm shall not issue any press releases, or divulge to the news media, either directly or indirectly, information regarding the specific location of, or other information that might endanger those resources, or their associated artifacts without first consulting with the Commission, and the State agency or political subdivision of the State that owns or controls the land where the resource has been discovered.

8) This permit may not be assigned by the Principal Investigator/Investigation Firm, Owner/Permittee, or Project Sponsor in whole, or in part to any other individual, organization, or corporation not specifically mentioned in this permit without the written consent of the Commission. 9) Hold Harmless: The Owner/Permittee hereby expressly releases the State and agrees that Owner/Permittee will hold harmless, indemnify, and defend (including reasonable attomey's fees and cost of litigation) the State, its officers, agents, and employees in their official and/or individual capacities from every liability, loss, or claim for damages to persons or property, direct or indirect of whatsoever nature arising out of, or in any way connected with, any of the activities covered under this permit. The provisions of this paragraph are solely for the benefit of the State and the Texas Historical Commission and are not intended to create or grant any rights, contractual or otherwise, to any other person or entity.

10) Addendum: The Owner/Permittee, Project Sponsor and Principal Investigator/Investigation Firm must abide by any addenda hereto attached.

Upon a finding that it is in the best interest of the State, this permit is issued on 09/15/2011.

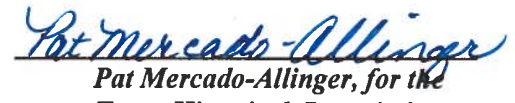

Texas Historical Commission 
Appendix A: Timeline of Events and Key Documents

\section{Attachment A4:}

Next-of-Kin Consent Form

Signed by Jesus Herrera

Camarena (Salvador Camarena's

son), May 28, 2012 


\section{CEMETERY CONSENT FORM}

I (We) hereby give our consent for the disinterment and removal of SAWADAR CAmAREAA who is buried in TXDOT ROW FM 481 maverick. Co.

(Name of Deceased)

(Plot \& Block) Our records indicate that the plot owner(s) is/are TExas DEPART MENT of TRANSPORTATI

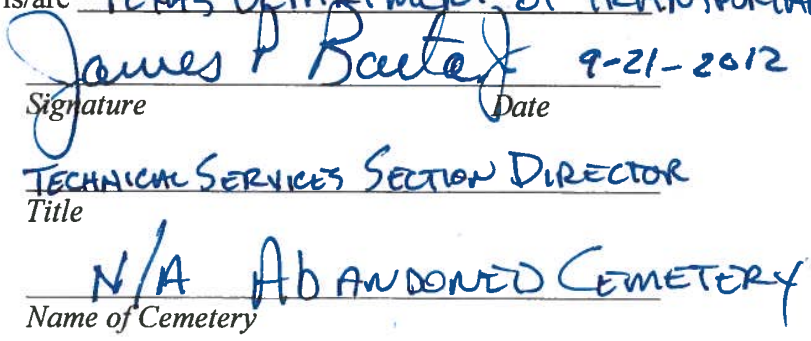

\section{PLOT OWNER CONSENT FORM}

I (We) hereby certify that we are the owner(s) of record ADANDONE D CEMETERey FM 481 in TXDOT ROW, MAUERKK Coeither by purchase or inheritance and we hereby (Plot) MAUORICK CO, TX. give our permission of the disinterment of SALVADOR CAMARENA who is buried in that plot.

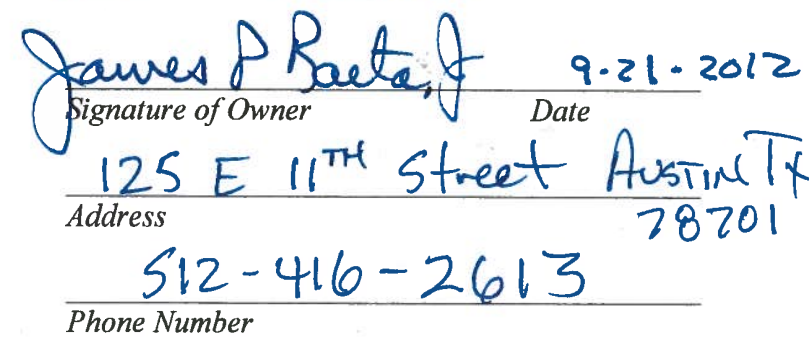

\section{NEXT-OF-KIN CONSENT FORM}

I hereby certify that I am the (Relationst of Salvador Camarena (Name of Deceased)

There are no other living relatives that precede me in the degree of kindred; and I give my permission for the body to be disinterred and moved to __La Marque Cemetery

(Name of Cemetery Where Body is to be Interred)

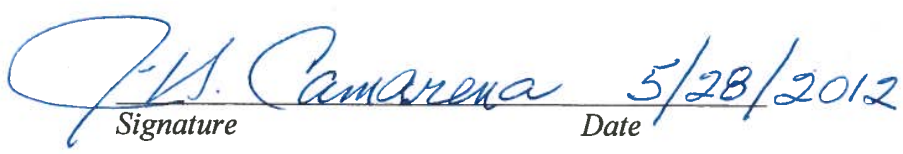

VS-271.17/2005

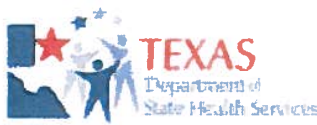




\section{Attachment A5:}

Court Order for Removal of

Cemetery Dedication,

Cause No. 12-08-27705-MCVAJA

Signed by the Maverick County

District Court Judge, 365th

Judicial District, August 22, 2012 
CAUSE No.12.08-27705-MUANA

IN RE:

THE STATE OF TEXAS AND

TEXAS DEPARTMENT OF

TRANSPORTATION

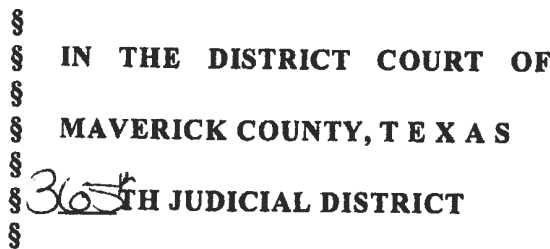

ORDER FOR REMOVAL OF CEMETERY DEDICATION WITHIN EXISTING RIGHT OF WAY (TEX. HEALTH AND SAFETY CODE SECTION 711.010)

On this date came on to be considered the Petition of the State of Texas for an order removing the cemetery dedication within the existing right of way of FM 481 in Maverick County, Texas.

Having considered the Application and the sworn testimony attached thereto, the Court finds that the requested relief should be granted.

It is therefore ORDERED, ADJUDGED, AND DECREED that the cemetery dedication is hereby removed from the property within the existing right of way of FM 481.

SIGNED this the 22 2012.

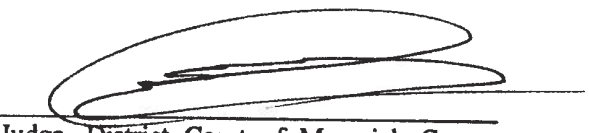

Judge, District Court of Maverick County,

Texas, 36J Judicial District

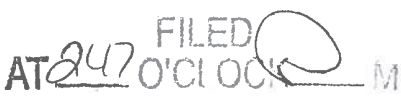

22

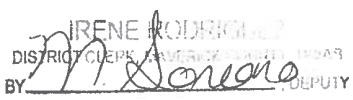




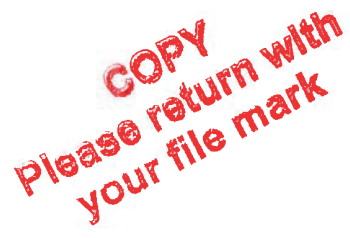

CAUSE No.12-08-27705-marAA

IN RE:
THE STATE OF TEXAS AND TEXAS
DEPARTMENT OF
TRANSPORTATION

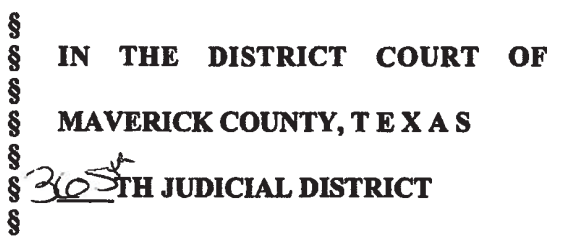

STATE OF TEXAS'APPLICATION FOR EXHUMATION, REMOVAL AND REINTERNMENT OF REMAINS OF PERSON BURIED WITHIN EXISTING RIGHT OF WAY (TEX. HEALTH AND SAFETY CODE SECTION 711.004)

TO THE HONORABLE JUDGE OF SAID COURT:

Comes now the STATE OF TEXAS, by and through its Department of Transportation ("TxDOT"), and pursuant to Texas Health and Safety Code ("Tex. H \& S Code") Sec. 711.004, presents this Application for an exparte order authorizing 1) the exhumation and removal of certain human remains from within the existing right of way of FM 481 in Maverick County ("the grave), and 2) the reinterment of said remains in a perpetual care cemetery, at the State's expense. This Application, which involves the remains of one individual, is necessitated by the location of the subject burial sites within the Right of Way of FM 481.

\section{Applicable Statutes}

Tex. H \& S. Code Sec. $711.010($ b) provides that:

"[o]n petition of the owner of the property, a district court of the county in which an unknown cemetery is discovered or an abandoned cemetery is located shall order the removal of any dedication for cemetery purposes that affects the property. If all human remains on the property have not previously been removed, the court shall order the removal of the human remains from the cemetery to a perpetualcare cemetery. A petition under this subsection shall be made ex parte in the name of the

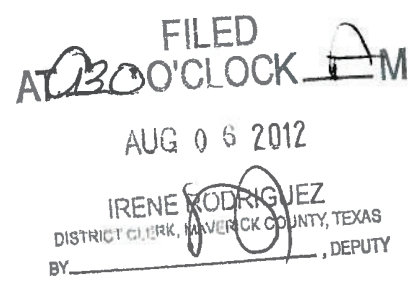


owner of the property without naming any defendant or joinder of any other person."

Tex. H \& S. Code Sec. 711.004 sets out the procedures and the notice normally required for the removal of human remains interred in a cemetery. A 'cemetery' is broadly defined by Tex. $\mathrm{H}$ \& S Code Sec. 711.001(2) as " a place that is used or intended to be used for interment...". Texas case law also broadly defined a "cemetery" as a place set apart, either by governmental authority or private enterprise, for the removal of the dead. Damon v. State, 52 S.W.2d368(Tex. Comm'n Appeals 1932).

Removal of human remains from a cemetery, and their relocation to another cemetery, normally requires the written consent of the following, if applicable: the cemetery organization operating the cemetery; the current plot owner or owners; and certain family members in named order of priority. Tex. H \& S Code Sec.711.004(a).

However, when the persons whose written consent is required for exhumation are not available to grant such consent (i.e., where such consent is not applicable or cannot be obtained), the remains may be removed "by permission of the county court of the county in which the cemetery is located." Tex. H \&S Code Sec. 711.004 (e). In such instances, where applicable and appropriate, Tex. H \& S Sec. 711.004(c) provides that notice must be given, prior to the date the application is heard, to the following parties: 1) the cemetery organization operating the cemetery in which the remains are interred; 2) each person whose consent is required for removal of remains under Subsection (a); and 3) any other person that the court requires to be served. As stated below, and by the attached sworn affidavit of Chris Ringstaff, the Texas Department of Transportation has identified the individual buried, as well as his surviving son who is his next of kin.

Tex. H \& S. Code Sec. 711.010 provides that the district court may also order the removal of 
any dedication for cemetery purposes that affects the property if the court finds that the removal of the dedication is in the public interest. See Tex. H \& S. Code Sec. 711.010 (a).

\section{Jurisdiction}

Tex. H \& S. Code Sec. 711.010 (b) provides for jurisdiction in the district court of the county in which an unknown cemetery is discovered or an abandoned cemetery is located. Tex. H \& S Code Sec. 711.004 (c) requires that notice of the Application for removal of human remains to be given to any cemetery organization and certain family members, as well as "any other person that the court requires to be served."

\section{Facts}

On August 18 2010, TxDOT archeologist Christopher Ringstaff was contacted by TxDOT Laredo District concerning a purported grave within TxDOT ROW on FM 481, Maverick County, Texas. The Laredo District was informed that the safety issue raised is a valid one and TxDOT should proceed through all the necessary steps to have the grave removed. On December 2010, subsequent to contacting local informants, a Geographic Information System analysis of the area revealed the location exhibited a grave marker symbol on the 1974 United States Geologic Survey Trosado Tank, Texas Topographic Quadrangle, which necessitated an investigation of the location by TxDOT Archeologists. The investigation verified the presence of a least one grave with the possibility of others as suggested by the plural "Graves" designation on the 1974 quadrangle.

On January 17, 2011, a survey within the FM 481 ROW was performed by a TxDOT archeologist to determine the presence or absence of a grave. Prior to fieldwork, e-mail correspondence and interviews with the County Historical Commission and Eagle Pass residents supplied contradictory information on whether the marker and enclosure were associated with a 
grave or an elaborate fatality marker thus necessitating verification. Scraping revealed the presence of a grave at which point excavations were immediately halted. The grave meets the definition of Abandoned Cemetery per 13TAC22.1(1). As such, a Notice of Existence of Cemetery was filed with the Maverick County Clerk per 13TAC22.4(a) on February 14, 2011. On February 17, 2011, The Texas Historical Commission concurred with TxDOTs findings.

On March 25, 2011, TxDOT published bilingual Public Notices for the March 27, April 3, and April 10 Sunday editions of Eagle Pass newspaper News Gram and also mailed notices to six local churches. On April 28, 2011, Property Owner Information requests were mailed to land owners in the immediate area

On September 29, 2011, a name plate was found in TxDOT Eagle Pass maintenance shop that read Salvador Camarena. In February 2012, genealogical research conducted by Prewitt and Associates, Inc. finds several of Salvador Camarena's relatives including his son, Jesus Camarena, who resides in Redding California. On March 6, 2012, Jesus Camarena requested reburial of his father at La Marque Cemetery in Galveston County where other family members are located. On June 1, 2012, TxDOT received a signed Reinternment Consent Form from Jesus Camarena and a plot was reserved at the La Marque Cemetery in Galveston County, Texas

\section{Relief Requested}

The State requests that the court sign and order allowing the removal of the remains to a perpetual care cemetery. Salvador Camerena's next of kin is his son, Mr. Jesus Camarena, who requested the remains be moved to a family plot at the La Marque Cemetery in Galveston County, Texas.

The State further requests the court remove the dedication of the site as a cemetery. The location of the grave is within the right of way of the State of Texas on FM 481. There is only 
one known grave at the site and once this grave is removed the site will cease to function as a burial site as defined by the Texas Health and Safety Code. Therefore, it is proper to remove the cemetery dedication from the land.

\section{Prayer}

WHEREFORE, PREMISES CONSIDERED, the State of Texas requests the Court to sign an order authorizing the Texas Department of Transportation to disinter and remove to an appropriate perpetual cemetery the human remains which are located in or in the immediate vicinity of the location, described herein as the "grave." In the alternative, should the Court believe that additional notice should be given, the State of Texas request that any prescribed statutory notice issue, and that after the publication of such notice the Court enter its order aforesaid. The State further requests the court remove the cemetery dedication from the site since no other graves are known to exist at that location.

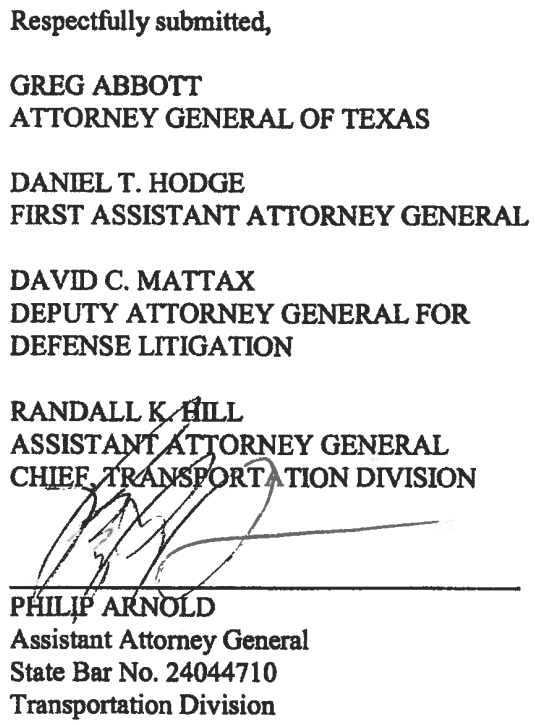


P.O. Box 12548

Austin, Texas 78711-2548

(512) 463-2004

(512) 472-3855 - Facsimile

ATTORNEYS FOR PLAINTIFF

THE STATE OF TEXAS 


\section{Attachment A6:}

Transmittal Letter and

Disinterment Permit

Issued by the Texas Department of

State Health Services,

Office of Vital Statistics,

September 21, 2012 


\section{TEXAS DEPARTMENT OF STATE HEALTH SERVICES} DAVID L. LAKEY, M.D.
COMMISSIONER

September 21, 2012

CHRISTOPHER RINGSTAFF

$125 \mathrm{E} 11 \mathrm{TH}$ ST

AUSTIN TEXAS 78701
P.O. Box 149347 Austin, Texas 78714-9347 1-888-963-7111 http://www.dshs.state.tx.us

TDD: $512-458-7708$

\author{
RE: SALVADOR CAMARENA \\ Died 01/17/1950 \\ Cert 009629 \\ Req. H007055 9/21/2012\$25.00
}

Dear Customer:

Thank you for contacting the Vital Statistics Unit. We have received and processed your request regarding the record identified above.

Enclosed are two copies of the requested Disinterment Permit. One is for your records and one for the sexton of the cemetery where is the body is being disinterred.

My telephone number and email address are listed below my name if you need any further assistance. Please do not hesitate to contact me.

Sincerely,

DEBBIE CHAMRERS

PROGRAM SPECIALIST

vital statistics

Phone: 512-776-7370

EMail: DEBBIE.CHAMBERS@DSHS.STATE.TX.US 


\section{DISINTERMENT PERMIT}

DEPARTMENT OF STATE HEALTH SERVICES, TEXAS VITAL STATISTICS

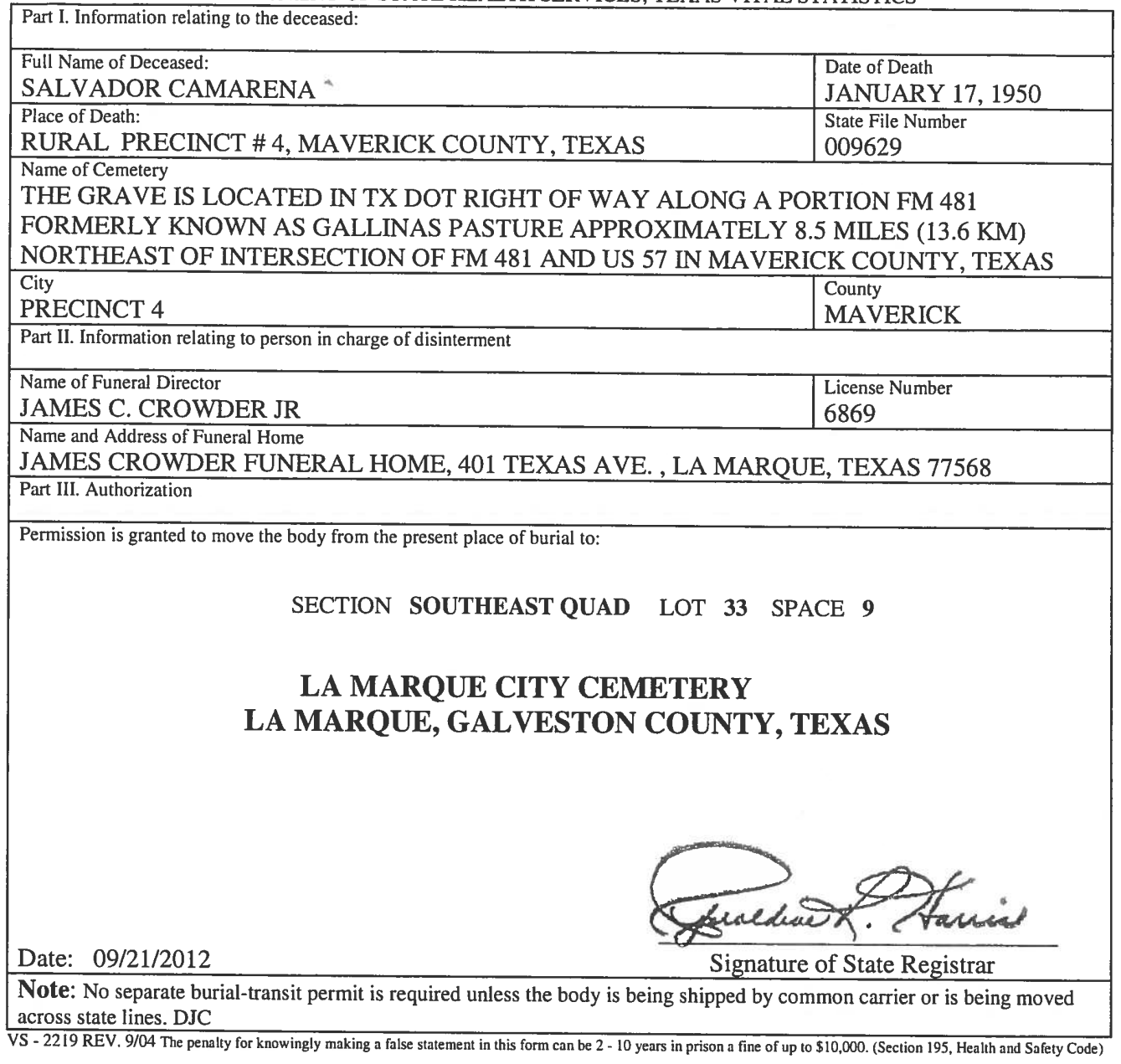





\section{APPENDIX B: Osteological Data for the Salvador Camarena Burial}

M. Katherine Spradley 



\section{INTRODUCTION}

This appendix includes all of the handwritten osteological data entry forms that were completed during the analysis of the skeletal remains.

1. Inventory Recording Form for Complete Skeletons
2. Adult Sex/Age Recording Form

3. Dental Inventory Recording Form

4. Dental Measurements and Morphology Recording Form

5. Enamel Defects Recording Form

6. Cranial Measurements Form

7. Poscranial Measurements Form 


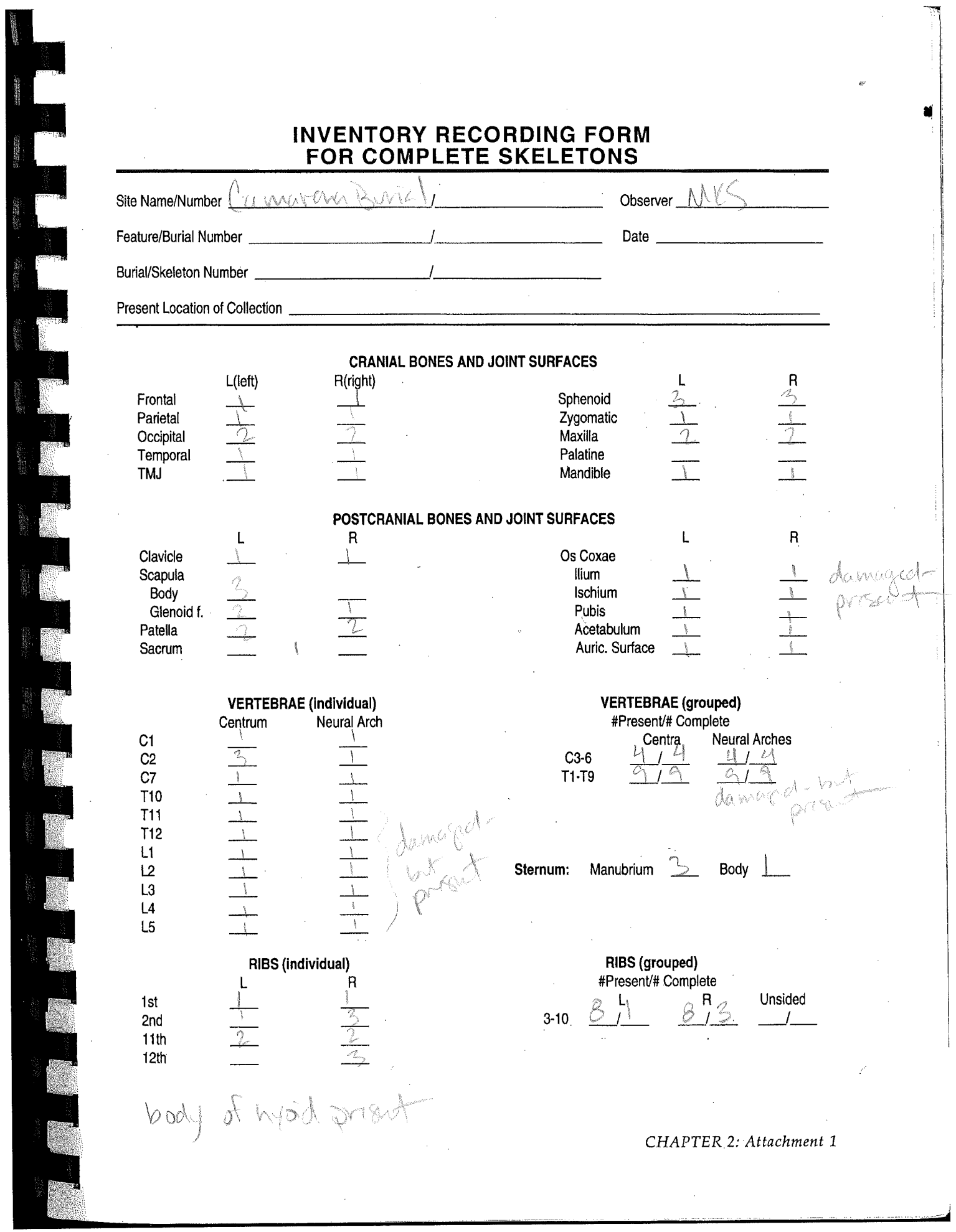




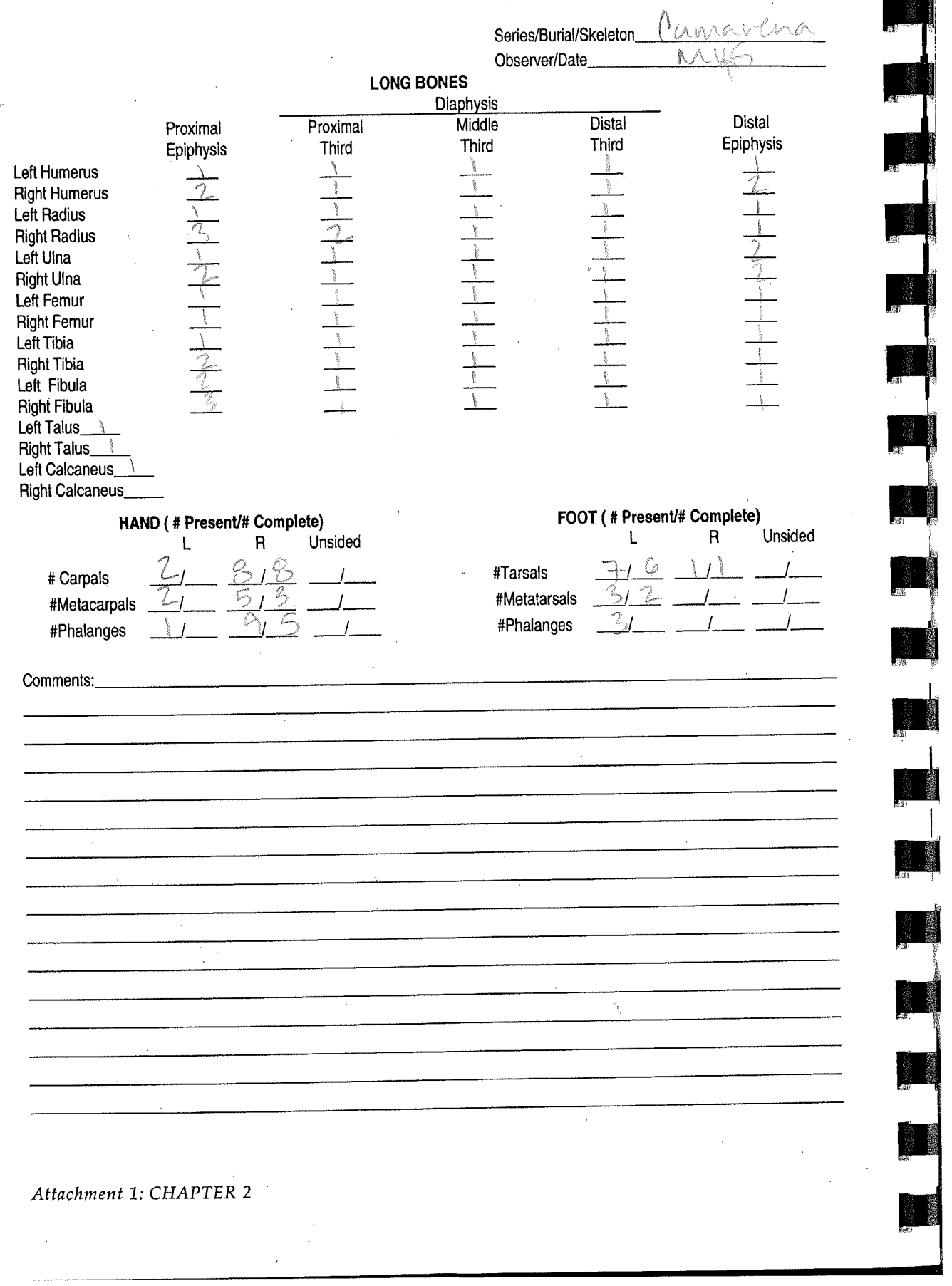




\section{ADULT SEXIAGE RECORDING FORM}

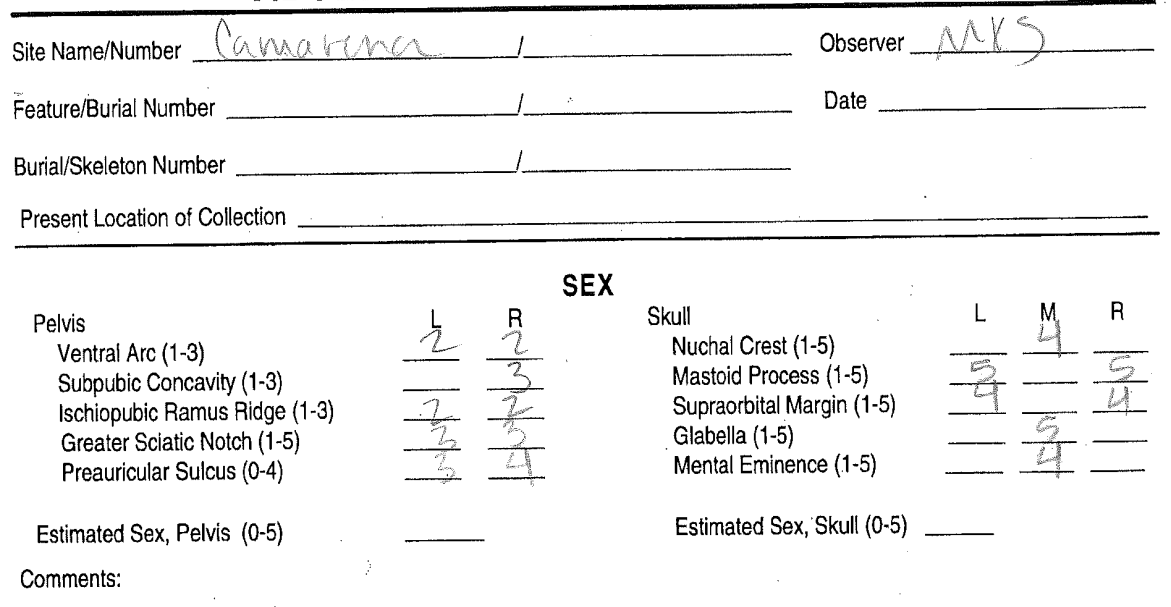

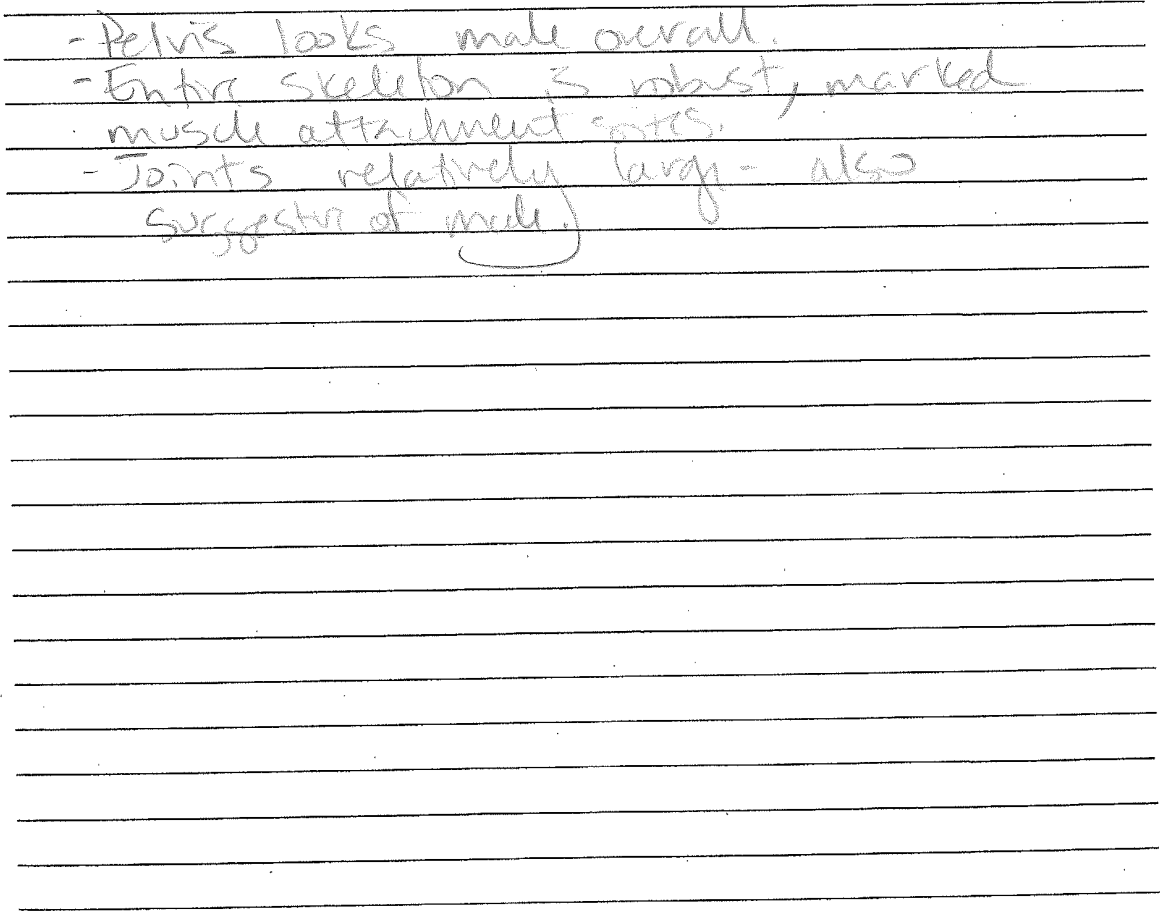

CHAPTER 3: Attachment 11 


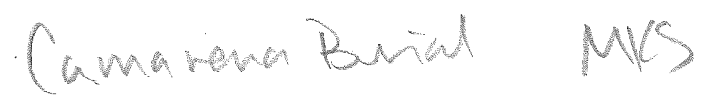

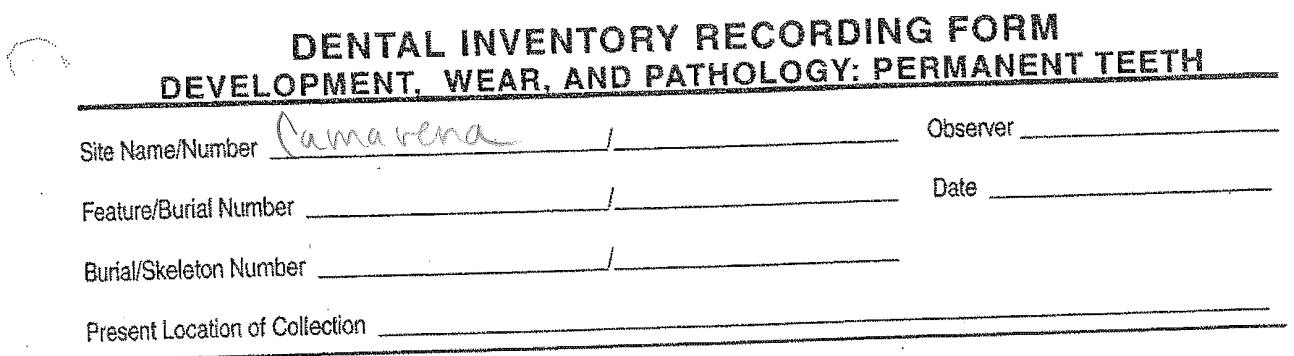

Tooth presence and development: code 1-8. For teeth entered as " $t$ " (present, but not in occtusion), record sto of crowntroot formation under "Development." Occlusal surface wear: use left teeth, record stage of crowhtoot tormalion undar Developmen Scott (1979) for molars (code 0-10). If maked following Smith (1984) for anterior teeth (code $1-8$ ) and Scott (197) for molars (code 010 ). If mackes provided $(t)$ asymmetry is present, record both sides. Record each molar quadrant separalo in the spaces prity $(1-7)$ i and the total for all four quadrants under "Total." Caries: code each catious lesion separately (1-7) Abscesses: code location (1-2). Calculus: code 0-3, 9. Note surtace affected (buccalhabial or ingua).

Tooth Presence Development Wear Total

Caries

Abscess

CalculusiAffected

Might

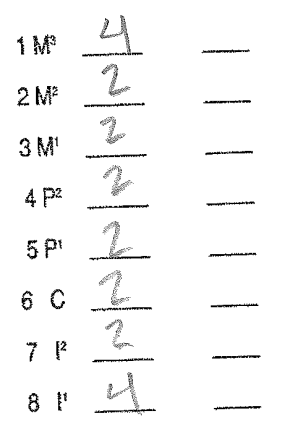

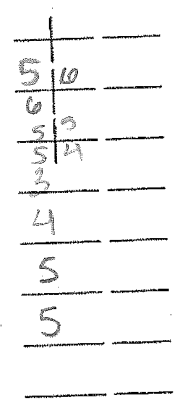

Maxillary

Left
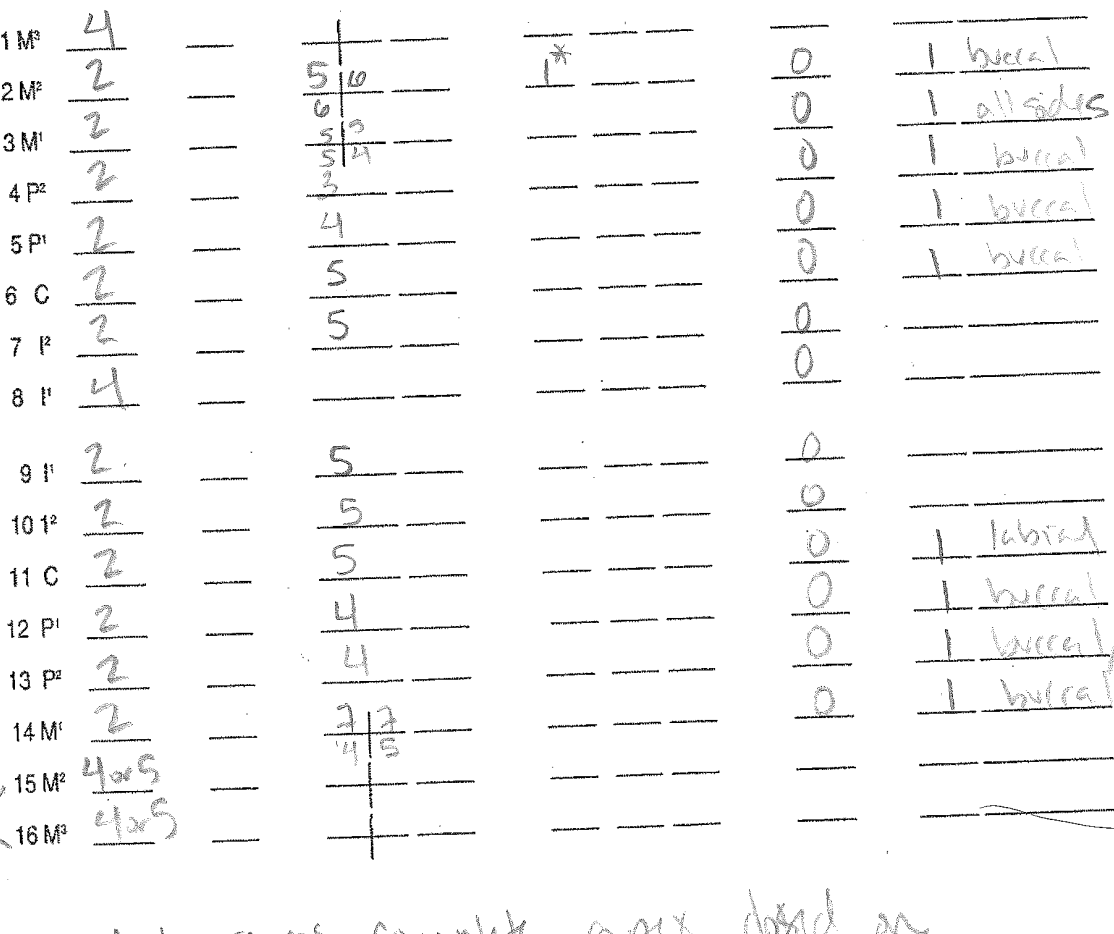

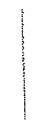


mild lo moldet

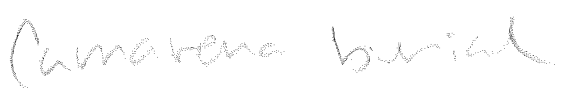

Series/Burialskeleton

ObserverDate

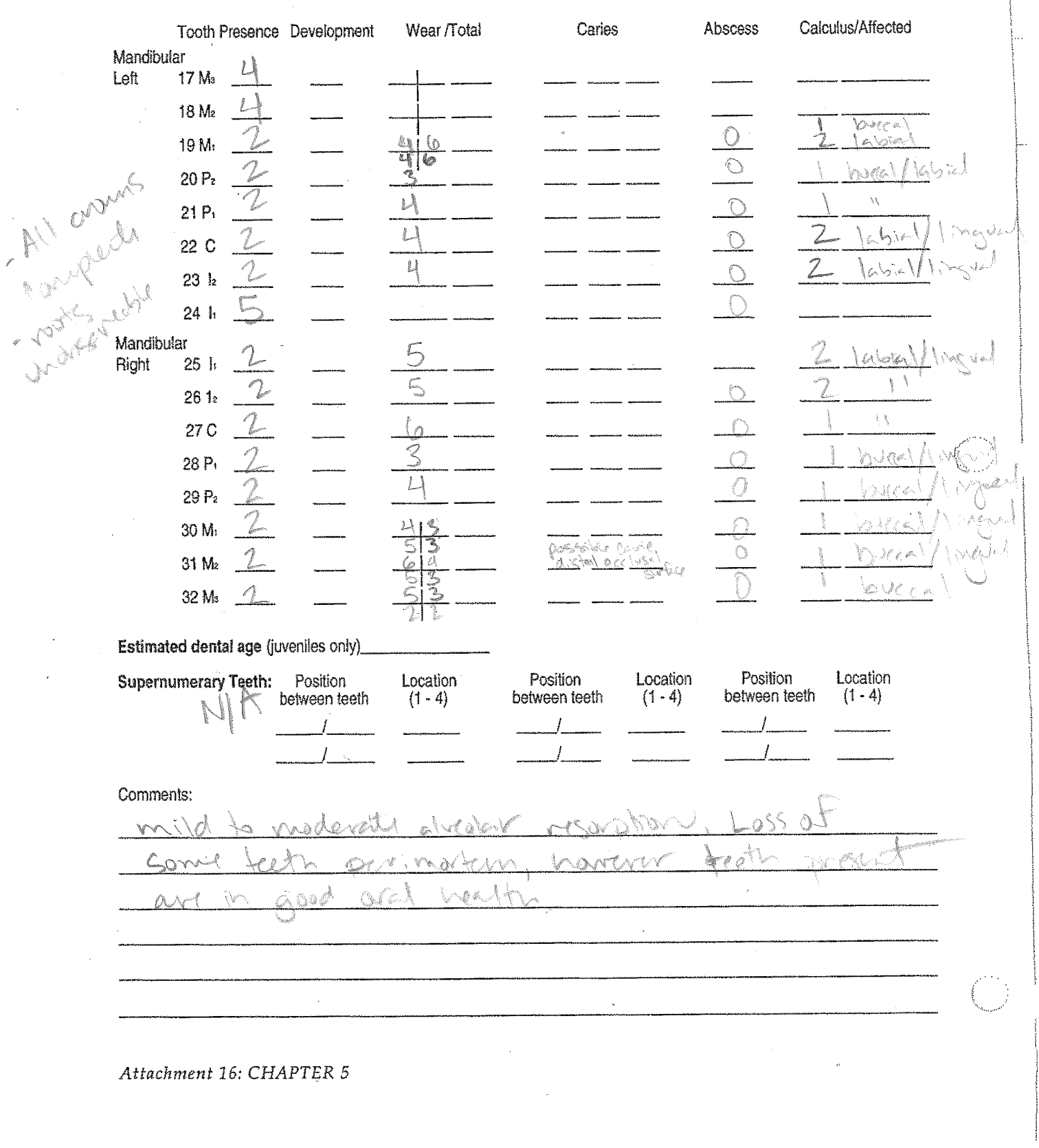




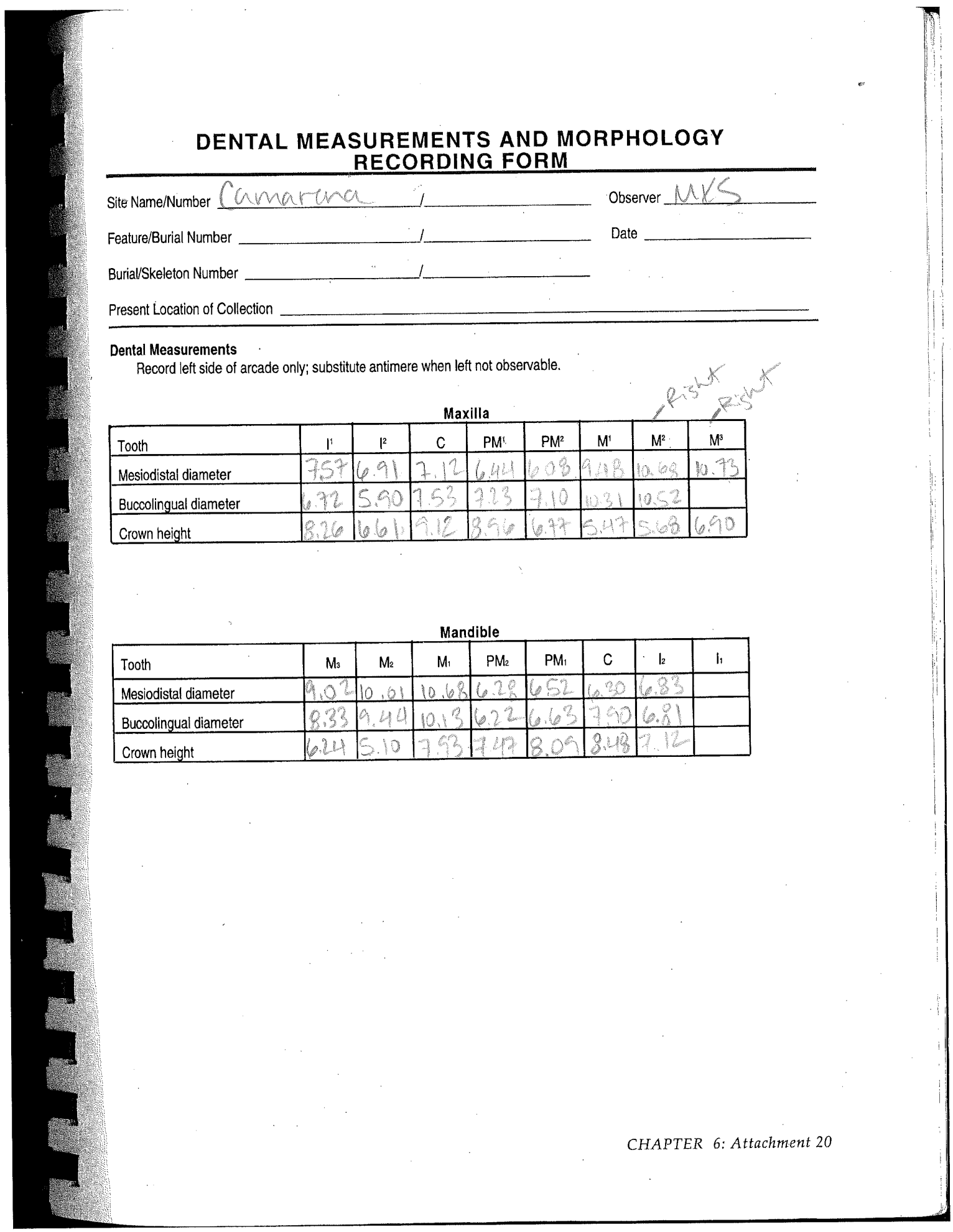




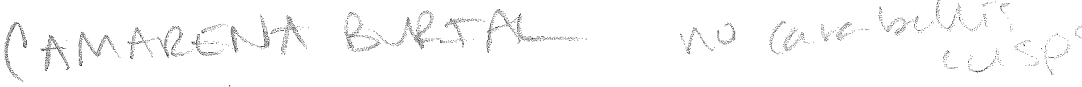

\section{ENAMEL DEFECTS (HYPOPLASIAS AND OPACITIES)} RECORDING FORM: PERMANENT TEETH

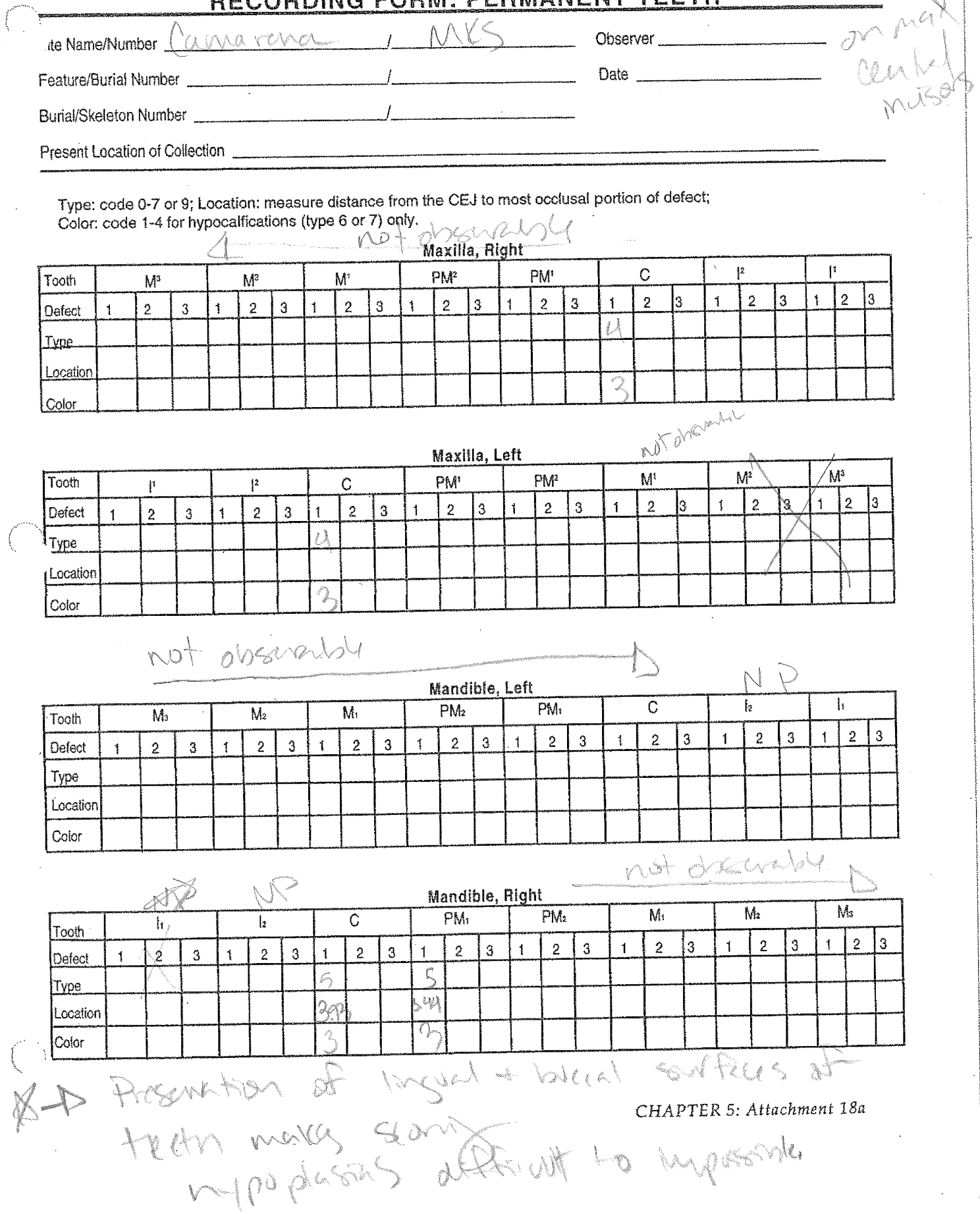




\section{Camamena Burit MYs 10/16/2012}

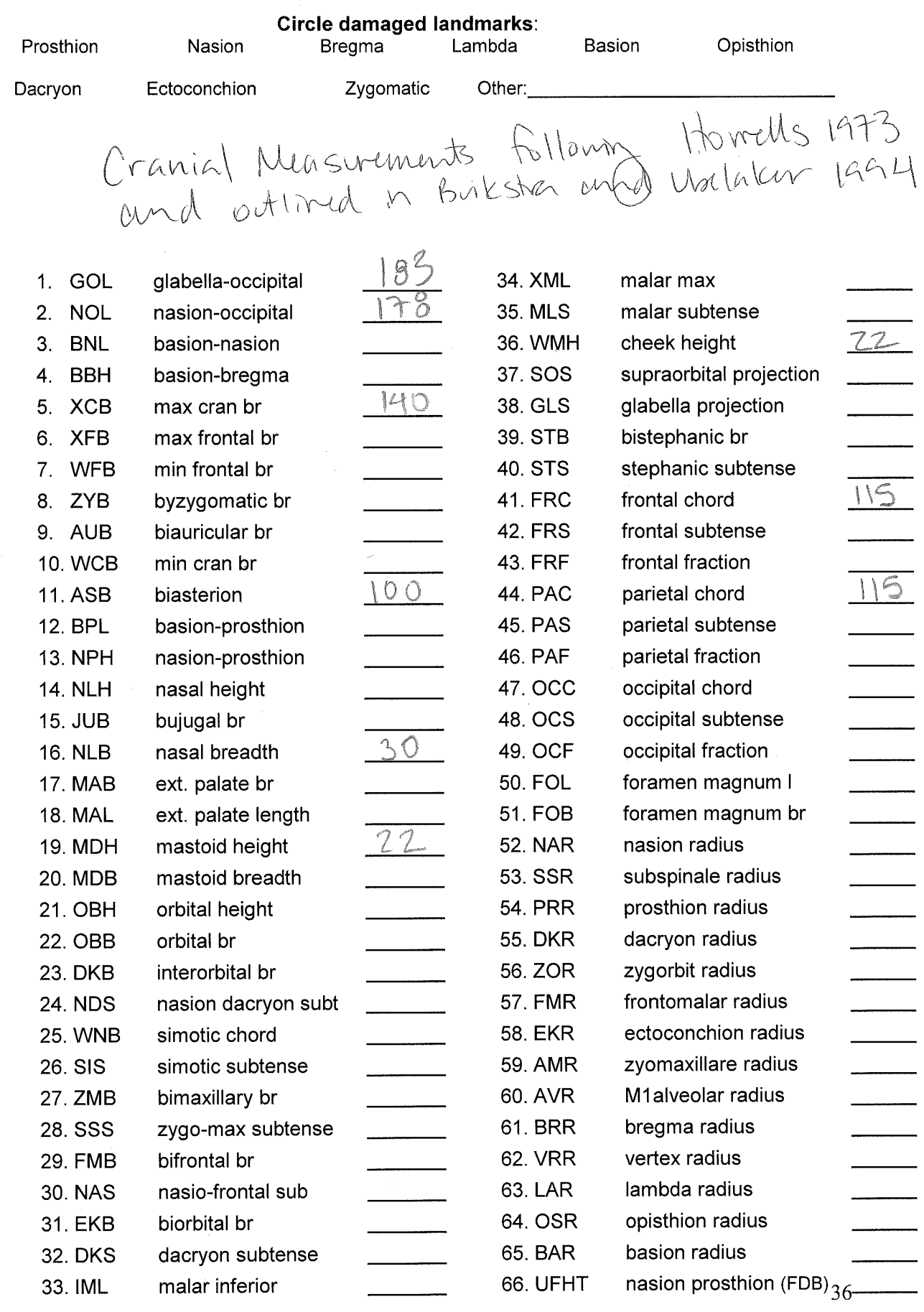


Postcranial Measurements

Case No. Camareng Recorder MYS Date $10 / 1012012$ Bunt

Postcranial Measurements

1. Clavicle max length*
2. Clavicle A-P diam midshaft*
3. Clav S-I diam midshaft*
4. Scapula max height*
5. Scapula max breadth*
6. Scapula spine length
7. Scapula supraspinous length
8. Scapula infraspinous length
9. Scap glenold cavity breadth
10. Scap glenoid cavity height
11. Scap glenoid to inf angle
12. Manubrium length
13. Mesosternum length
14. Stenebra 1 width
15. Stenebra 3 width
16. Humerus max length*
17. Hum prox epiph breadth
18. Hum max diam midshaft*
19. Hum min diam midshaft*
20. Hum max vert diam head*
21. Hum epicondylar breadth*
22. Hum least circum of shaft
23. Radius max length*
24. Radius max diam head
25. Radius A-P diam of shaft*
26. Radius M-L diam of shaft*
27. Radius neck shaft circum
28. Uina max length*
29. Ulna physiological length*
30. Ulna max br olecranon
31. Ulna min br olecranon
32. Ulna max wd olecranon
33. Ulna olec-radial notch
34. Ulna olec-coronoid length

\begin{tabular}{|c|c|c|}
\hline (CML-CLAXLN) & $\begin{array}{l}\text { Left } \\
4^{2}\end{array}$ & Right \\
\hline (CSD-CLAAPD) & & \\
\hline (CVD-CLAVRD) & & \\
\hline (SML-SCAPHT) & & \\
\hline (SMB-SCAPBP) & & \\
\hline (SLS) & & \\
\hline (SSL) & & \\
\hline (ISL) & & \\
\hline (GCB) & & $d+$ \\
\hline$(\mathrm{GCH})$ & & \\
\hline (GIL) & & \\
\hline (MML) & & \\
\hline (MSL) & & \\
\hline (S1W) & & \\
\hline$(\mathrm{S} 3 \mathrm{~W})$ & & \\
\hline (HML-HUMXLN) & & \\
\hline (BUE) & & \\
\hline (MDS-HUMMXD) & 22 & $(2,2)$ \\
\hline (DM-HUMMWD) & 21 & 20 \\
\hline (MDH-HUMHDD) & 45 & \\
\hline (EBR-HUMEBR) & & \\
\hline (LCS) & & \\
\hline (RML-RADXLN) & 26 & \\
\hline (RDH) & $\frac{24}{9}$ & \\
\hline (RSD-RADAPD) & 13 & \\
\hline (RTD-RADTVD) & & \\
\hline (MCS) & 50 & \\
\hline (UML-ULNXLN) & & \\
\hline (UPL-ULNPHL) & $20 \%$ & \\
\hline (BOP) & & \\
\hline (MBO) & 20 & \\
\hline (WOP) & 2.8 & \\
\hline (ORL) & 37 & \\
\hline (OCL) & & \\
\hline
\end{tabular}

35. Uina A-P diam shaft

$\begin{array}{lll}\text { (UAB-ULNDVD) } & 15 & \text { Left } \\ \text { (UMD-ULNTVD) } & 15 & - \\ \text { (UMD-ULNCIR) } & 33 & - \\ \text { (SAL-SACAHT) } & - \\ \text { (SAB-SACABR) } & - \\ \text { (SMB-SACS1B) } & - \\ \text { (INH-INNOHT) } \\ \text { (ILB-ILIABR) }\end{array}$

(FML-FEMXLN) $\longdiv { 4 2 0 } \overline { 4 2 2 }$

(FOL-FEMBLN) 4110 419

(FTL) $388 \quad \overline{392}$

(APD-FEMSAP) $32 \quad 32$

(MLD-FEMSTV) $20 \quad 26$

(APS-FEMMAP) $29 \quad 29$

(MLS-FEMMTV) $29 \quad 28$

(VDH-FEMHDD) - $\frac{28}{45}$

(HHD) 47 45

(APL) $-\frac{15}{65}$

(APM) $\frac{65}{65}$

(FEB-FEMEBR) —

$(\mathrm{BCB})-\frac{71}{31}$

(VDN) $\quad 31$

(FCS-FEMCIR) 89 88

(TML-TIBXLN) $330 \quad 332$

(BPE-TIBPEB)

(BDE-TIBDEB)

(APN-TIBNFX) $35 \quad 35$

(MLM-TIBNFT) 20

(CFL) $10^{4}(110)$

(PCN-TIBCIR) 959

(BML-FIBXLN)

(FMD-FIBMDM) $1(\rho)$

(CLL-CALCXL) 7 ?

(CMB-CAlcbr) 4

Numbers refer to associated Zobeck definition

* Standard measurements from Buikstra and Ubelaker 1994

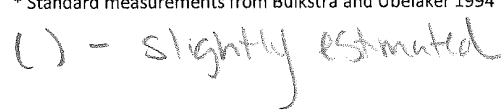

